Prepared in cooperation with the

Pennsylvania Department of Environmental Protection, Eastern Pennsylvania Coalition for Abandoned Mine Reclamation, and Dauphin County Conservation District

\title{
Water Budgets and Groundwater Volumes for Abandoned Underground Mines in the Western Middle Anthracite Coalfield, Schuylkill, Columbia, and Northumberland Counties, Pennsylvania-Preliminary Estimates with Identification of Data Needs
}

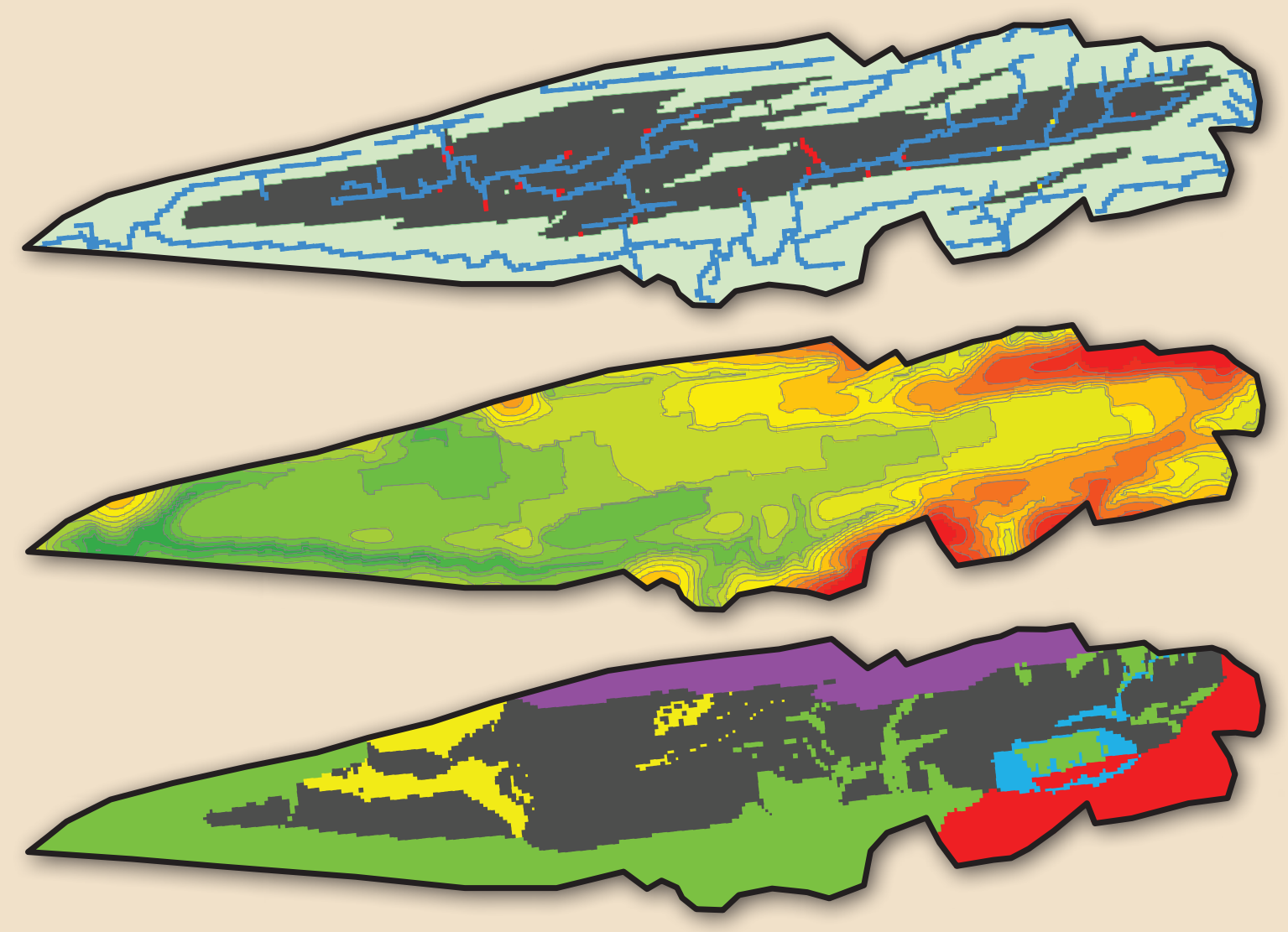

Scientific Investigations Report 2010-5261 
Cover. Details of figures 9,16 , and 17 showing features of the groundwater-flow model used to determine water budgets and groundwater volumes. 


\section{Water Budgets and Groundwater Volumes for Abandoned Underground Mines in the Western Middle Anthracite Coalfield, Schuylkill, Columbia, and Northumberland Counties, Pennsylvania-Preliminary Estimates with Identification of Data Needs}

By Daniel J. Goode, Charles A. Cravotta III, Roger J. Hornberger,

Michael A. Hewitt, Robert E. Hughes, Daniel J. Koury, and Lee W. Eicholtz

Prepared in cooperation with the

Pennsylvania Department of Environmental Protection, Eastern Pennsylvania Coalition for Abandoned Mine Reclamation, and Dauphin County Conservation District

Scientific Investigations Report 2010-5261 


\title{
U.S. Department of the Interior \\ KEN SALAZAR, Secretary \\ U.S. Geological Survey \\ Marcia K. McNutt, Director
}

\author{
U.S. Geological Survey, Reston, Virginia: 2011
}

For more information on the USGS - the Federal source for science about the Earth, its natural and living resources, natural hazards, and the environment, visit http://www.usgs.gov or call 1-888-ASK-USGS

For an overview of USGS information products, including maps, imagery, and publications, visit http://www.usgs.gov/pubprod

To order this and other USGS information products, visit http://store.usgs.gov

Any use of trade, product, or firm names is for descriptive purposes only and does not imply endorsement by the U.S. Government.

Although this report is in the public domain, permission must be secured from the individual copyright owners to reproduce any copyrighted materials contained within this report.

Suggested citation:

Goode, D.J., Cravotta, C.A., III, Hornberger, R.J., Hewitt, M.A., Hughes, R.E., Koury., D.J., and Eicholtz, L.W., 2011, Water budgets and groundwater volumes for abandoned underground mines in the Western Middle Anthracite Coalfield, Schuylkill, Columbia, and Northumberland Counties, Pennsylvania-Preliminary estimates with identification of data needs: U.S. Geological Survey Scientific Investigations Report 2010-5261, 54 p. 


\section{Contents}

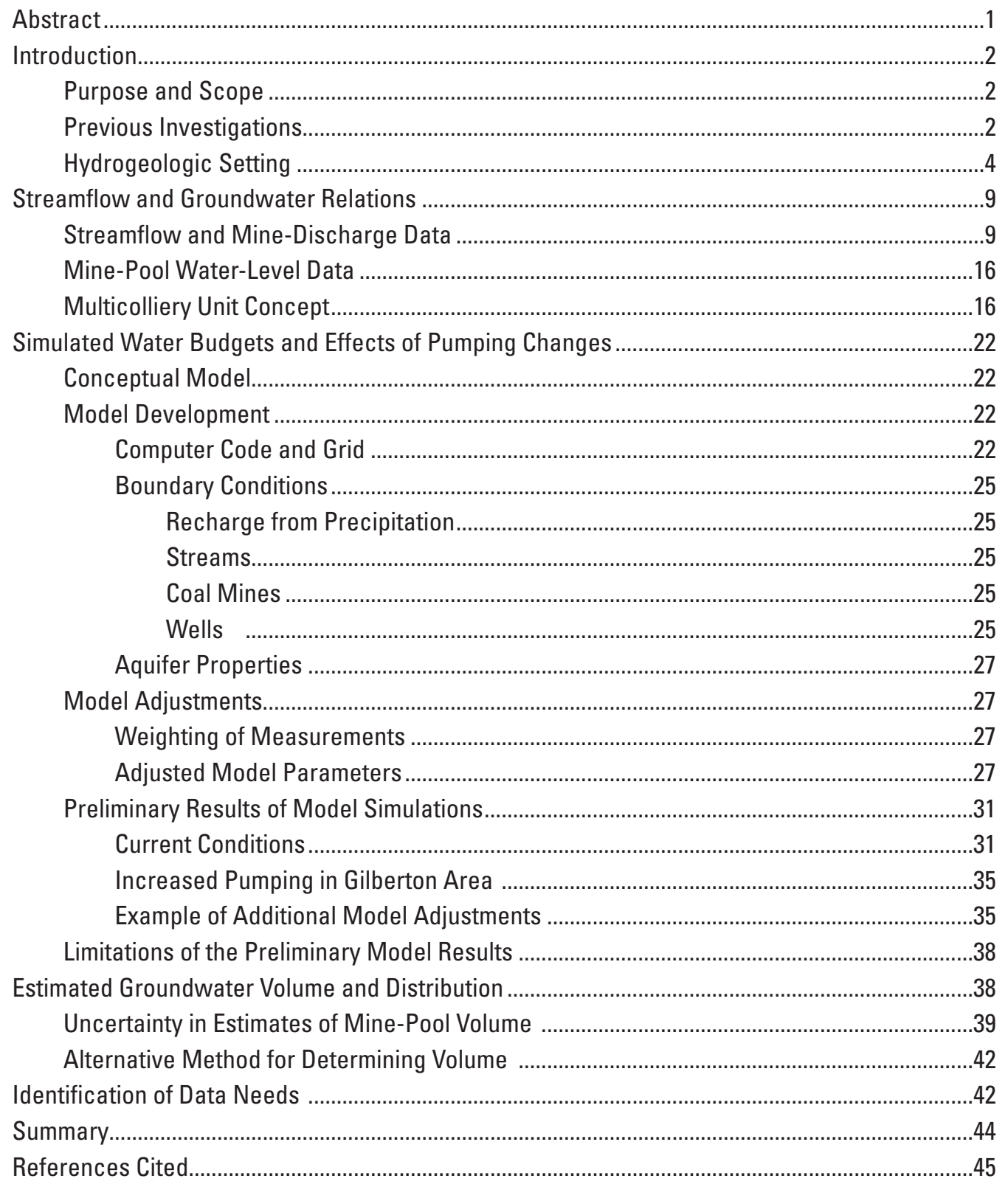




\section{Figures}

1-2. Maps showing-

1. Surface drainage, selected municipalities, and study-area boundary within Schuylkill, Columbia, and Northumberland Counties, Pennsylvania

2. Principal bedrock units and sites within Shamokin and Mahanoy Creek Basins, Schuylkill, Columbia, and Northumberland Counties, Pennsylvania, where mine discharges and streamflow were measured by the U.S. Geological Survey in 1999-2001

3. Cross sections showing structural geology of the Western Middle Anthracite Coalfield, Schuylkill, Columbia, and Northumberland Counties, Pennsylvania..

4. Map showing simplified structural contours of the Buck Mountain coalbed used to develop the groundwater-flow model of the Western Middle Anthracite Coalfield, Schuylkill, Columbia, and Northumberland Counties, Pennsylvania

5. Graph showing total annual precipitation during 1941 to 2008 for Mahanoy City and Tamaqua, Pennsylvania

6-9. Maps showing-

6. Estimated streamflow yields of surface drainage sub-basins within Shamokin and Mahanoy Creek Basins, Schuylkill, Columbia, and Northumberland Counties, Pennsylvania, 1999-2001

7. Approximate locations of principal collieries, barrier pillars, and tunnels within the Western Middle Anthracite Coalfield, Schuylkill, Columbia, and Northumberland Counties, Pennsylvania

8. Conceptual multicolliery hydrogeologic units and locations of associated groundwater-level, mine-discharge, and streamflow data used to develop the groundwater-flow model of the Western Middle Anthracite Coalfield, Schuylkill, Columbia, and Northumberland Counties, Pennsylvania...

9. Finite-difference grid and location of mined area, stream cells, and pumpingwell cells for the groundwater-flow model of the Western Middle Anthracite Coalfield, Schuylkill, Columbia, and Northumberland Counties, Pennsylvania.......23

10. Cross sections of finite-difference grid along $(A)$ row 36 and $(B)$ column 170 for the groundwater-flow model of the Western Middle Anthracite Coalfield, Schuylkill, Columbia, and Northumberland Counties, Pennsylvania

11-12. Maps showing -

11. Altitude of the bottom of model layer 3 for the groundwater-flow model of the Western Middle Anthracite Coalfield, Schuylkill, Columbia, and Northumberland Counties, Pennsylvania

12. Locations of high- and low-permeability barriers between mines for the groundwater-flow model of the Western Middle Anthracite Coalfield, Schuylkill, Columbia, and Northumberland Counties, Pennsylvania

13. Bar graph showing composite scaled sensitivity of hydraulic parameters used in the groundwater-flow model of the Western Middle Anthracite Coalfield, Schuylkill, Columbia, and Northumberland Counties, Pennsylvania. 
14-15. Plots showing-

14. Relation between observed and simulated groundwater levels simulated by use of the groundwater-flow model of the Western Middle Anthracite Coalfield, Schuylkill, Columbia, and Northumberland Counties, Pennsylvania

15. Relation between observed and simulated base-flow gain or loss simulated by use of the groundwater-flow model of the Western Middle Anthracite Coalfield, Schuylkill, Columbia, and Northumberland Counties, Pennsylvania

16-19. Maps showing-

16. Water-table altitude for current conditions simulated by use of the groundwaterflow model of the Western Middle Anthracite Coalfield, Schuylkill, Columbia, and Northumberland Counties, Pennsylvania

17. Areas contributing precipitation recharge to mine discharges, pumping wells, and streams for current conditions simulated by use of the groundwater-flow model of the Western Middle Anthracite Coalfield, Schuylkill, Columbia, and Northumberland Counties, Pennsylvania

18. Rate of volumetric recharge from streams for current conditions simulated by use of the groundwater-flow model of the Western Middle Anthracite Coalfield, Schuylkill, Columbia, and Northumberland Counties, Pennsylvania.......34

19. Regional steady-state drawdown in layer 3 with increased pumping of minepool water in the Gilberton area and areas contributing recharge from precipitation to different discharges simulated by use of the groundwater-flow model of the Western Middle Anthracite Coalfield, Schuylkill, Columbia, and Northumberland Counties, Pennsylvania

20-21. Screen captures showing-

20. Modifications to mine-barrier hydraulic conductivity for alternative groundwater-flow model for the Western Middle Anthracite Coalfield, Schuylkill, Columbia, and Northumberland Counties, Pennsylvania

21. Generalized dip angles for use in estimating mine-pool volumes using a hydrogeologic model for the Western Middle Anthracite Coalfield, Schuylkill, Columbia, and Northumberland Counties, Pennsylvania.

22. Schematic cross section of flooded mine complex showing the groundwater table in overlying, mined coalbeds and the portion of the surface area of the mined coalbed where water-table storage capacity is effective. 


\section{Tables}

1. Average thicknesses and relative altitudes of economically important coalbeds above the Buck Mountain coalbed in the Western Middle Anthracite Coalfield in eastern Pennsylvania

2. Site descriptions and estimated streamflow yields for surface drainage sub-basins within Shamokin and Mahanoy Creek Basins, Schuylkill, Columbia, and Northumberland Counties, Pennsylvania, 1999-2001

3. Site descriptions and flow rates of abandoned mine discharges in the Western Middle Anthracite Coalfield, Schuylkill, Columbia, and Northumberland Counties, Pennsylvania, 1999-2001

4. Name, year of closure, estimated area, and altitude of deepest mining of collieries in the Western Middle Anthracite Coalfield, Schuylkill, Columbia, and Northumberland Counties, Pennsylvania

5. Locations of boreholes and altitudes of groundwater used to estimate volume of water stored in underground mines and to adjust the groundwater-flow model of the Western Middle Anthracite Coalfield, Schuylkill, Northumberland, and Columbia Counties, Pennsylvania

6. Names, areas, estimated discharge, and measured discharge from multicolliery hydrologic units in the Western Middle Anthracite Coalfield in eastern

Pennsylvania

7. Parameters used in the groundwater-flow model of Western Middle Anthracite Coalfield, Schuylkill, Columbia, and Northumberland Counties, Pennsylvania..

8. Water budget for current conditions simulated by use of the groundwater-flow model of the Western Middle Anthracite Coalfield, Schuylkill, Columbia, and Northumberland Counties, Pennsylvania

9. Water budget for increased pumping from mine pool in Gilberton area simulated by use of the groundwater-flow model of the Western Middle Anthracite Coalfield, Schuylkill, Columbia, and Northumberland Counties, Pennsylvania

10. Estimated storage volumes and discharges of groundwater by flooded underground mines in the Western Middle Anthracite Coalfield, Schuylkill, Northumberland, and Columbia Counties, Pennsylvania

11. Estimated storage volumes and average residence times of groundwater in the mine pools considering different porosities for mined coalbeds in the Western Middle Anthracite Coalfield, Schuylkill, Northumberland, and Columbia Counties, Pennsylvania, 1999-2001 


\section{Conversion Factors and Datums}

\begin{tabular}{|c|c|c|}
\hline Multiply & By & To obtain \\
\hline \multicolumn{3}{|c|}{ Length } \\
\hline inch (in.) & 2.54 & centimeter $(\mathrm{cm})$ \\
\hline inch (in.) & 25.4 & millimeter (mm) \\
\hline foot $(\mathrm{ft})$ & 0.3048 & meter $(\mathrm{m})$ \\
\hline mile (mi) & 1.609 & kilometer $(\mathrm{km})$ \\
\hline \multicolumn{3}{|c|}{ Area } \\
\hline square mile $\left(\mathrm{mi}^{2}\right)$ & 2.590 & square kilometer $\left(\mathrm{km}^{2}\right)$ \\
\hline \multicolumn{3}{|c|}{ Volume } \\
\hline gallon (gal) & 0.003785 & cubic meter $\left(\mathrm{m}^{3}\right)$ \\
\hline gallon (gal) & 3.785 & cubic decimeter $\left(\mathrm{dm}^{3}\right)$ \\
\hline million gallons (Mgal) & 3,785 & cubic meter $\left(\mathrm{m}^{3}\right)$ \\
\hline billion gallons (Bgal) & $3,785,000$ & cubic meter $\left(\mathrm{m}^{3}\right)$ \\
\hline cubic foot $\left(\mathrm{ft}^{3}\right)$ & 0.02832 & cubic meter $\left(\mathrm{m}^{3}\right)$ \\
\hline acre-foot (acre-ft) & 1,233 & cubic meter $\left(\mathrm{m}^{3}\right)$ \\
\hline \multicolumn{3}{|c|}{ Flow rate } \\
\hline cubic foot per second $\left(\mathrm{ft}^{3} / \mathrm{s}\right)$ & 0.02832 & cubic meter per second $\left(\mathrm{m}^{3} / \mathrm{s}\right)$ \\
\hline gallon per minute (gal/min) & 0.06309 & liter per second $(\mathrm{L} / \mathrm{s})$ \\
\hline gallon per day (gal/d) & 3.785 & liter per day $(\mathrm{L} / \mathrm{d})$ \\
\hline million gallons per day $(\mathrm{Mgal} / \mathrm{d})$ & 0.04381 & cubic meter per second $\left(\mathrm{m}^{3} / \mathrm{s}\right)$ \\
\hline inch per year (in/yr) & 2.54 & centimeter per year (cm/yr) \\
\hline mile per hour (mi/h) & 1.609 & kilometer per hour $(\mathrm{km} / \mathrm{h})$ \\
\hline \multicolumn{3}{|c|}{ Hydraulic conductivity } \\
\hline foot per day (ft/d) & 0.3048 & meter per day $(\mathrm{m} / \mathrm{d})$ \\
\hline
\end{tabular}

Vertical coordinate information is referenced to the National Geodetic Vertical Datum of 1929 (NGVD 29).

Horizontal coordinate information is referenced to the North American Datum of 1983 (NAD 83).

Altitude, as used in this report, refers to distance above the vertical datum. 
(This page intentionally left blank.) 


\title{
Water Budgets and Groundwater Volumes for Abandoned Underground Mines in the Western Middle Anthracite Coalfield, Schuylkill, Columbia, and Northumberland Counties, Pennsylvania-Preliminary Estimates with Identification of Data Needs
}

\author{
Daniel J. Goode', Charles A. Cravotta III', Roger J. Hornberger², Michael A. Hewitt', Robert E. Hughes ${ }^{3}$, \\ Daniel J. Koury ${ }^{4}$, and Lee W. Eicholtz ${ }^{1}$
}

\begin{abstract}
This report, prepared in cooperation with the Pennsylvania Department of Environmental Protection (PaDEP), the Eastern Pennsylvania Coalition for Abandoned Mine Reclamation, and the Dauphin County Conservation District, provides estimates of water budgets and groundwater volumes stored in abandoned underground mines in the Western Middle Anthracite Coalfield, which encompasses an area of 120 square miles in eastern Pennsylvania. The estimates are based on preliminary simulations using a groundwater-flow model and an associated geographic information system that integrates data on the mining features, hydrogeology, and streamflow in the study area. The Mahanoy and Shamokin Creek Basins were the focus of the study because these basins exhibit extensive hydrologic effects and water-quality degradation from the abandoned mines in their headwaters in the Western Middle Anthracite Coalfield. Proposed groundwater withdrawals from the flooded parts of the mines and stream-channel modifications in selected areas have the potential for altering the distribution of groundwater and the interaction between the groundwater and streams in the area.

Preliminary three-dimensional, steady-state simulations of groundwater flow by the use of MODFLOW are presented to summarize information on the exchange of groundwater among adjacent mines and to help guide the management of ongoing data collection, reclamation activities, and water-use planning. The conceptual model includes high-permeability mine voids that are connected vertically and horizontally
\end{abstract}

\footnotetext{
${ }^{1}$ USGS Pennsylvania Water Science Center.

${ }^{2}$ Independent consultant (deceased).

${ }^{3}$ Eastern Pennsylvania Coalition for Abandoned Mine Reclamation.

${ }^{4}$ Pennsylvania Department of Environmental Protection.
}

within multicolliery units (MCUs). MCUs were identified on the basis of mine maps, locations of mine discharges, and groundwater levels in the mines measured by PaDEP. The locations and integrity of mine barriers were determined from mine maps and groundwater levels. The permeability of intact barriers is low, reflecting the hydraulic characteristics of unmined host rock and coal.

A steady-state model was calibrated to measured groundwater levels and stream base flow, the latter at many locations composed primarily of discharge from mines. Automatic parameter estimation used MODFLOW-2000 with manual adjustments to constrain parameter values to realistic ranges. The calibrated model supports the conceptual model of highpermeability MCUs separated by low-permeability barriers and streamflow losses and gains associated with mine infiltration and discharge. The simulated groundwater levels illustrate low groundwater gradients within an MCU and abrupt changes in water levels between MCUs. The preliminary model results indicate that the primary result of increased pumping from the mine would be reduced discharge from the mine to streams near the pumping wells. The intact barriers limit the spatial extent of mine dewatering. Considering the simulated groundwater levels, depth of mining, and assumed bulk porosity of 11 or 40 percent for the mined seams, the water volume in storage in the mines of the Western Middle Anthracite Coalfield was estimated to range from 60 to 220 billion gallons, respectively.

Details of the groundwater-level distribution and the rates of some mine discharges are not simulated well using the preliminary model. Use of the model results should be limited to evaluation of the conceptual model and its simulation using porous-media flow methods, overall water budgets for the Western Middle Anthracite Coalfield, and approximate storage volumes. Model results should not be considered accurate for detailed simulation of flow within a single MCU or individual flooded mine. Although improvements in the model calibration were possible by introducing spatial variability in permeability 
parameters and adjusting barrier properties, more detailed parameterizations have increased uncertainty because of the limited data set.

The preliminary identification of data needs includes continuous streamflow, mine discharge rate, and groundwater levels in the mines and adjacent areas. Data collected when the system is responding to hydrologic stresses such as recharge or pumping changes would provide information on hydraulic barrier integrity and groundwater/surface-water exchanges; the latter would also be informed by tracer studies and streambed surveys. Use of transient simulations, calibrated with transient measurements, is suggested to provide an independent estimate of the storage capacity of the mines.

\section{Introduction}

Although once a scene of vital coal-mining activity, landscapes containing legacy anthracite mines in eastern Pennsylvania presently are among the most disturbed and economically depressed in the northeastern United States. Once thriving towns such as Mahanoy City, Gilberton, Centralia, Ashland, Shamokin, and Trevorton in the Western Middle Anthracite Coalfield of Schuylkill, Columbia, and Northumberland Counties (fig. 1) have declined in population by half or more since 1920 (Marsh, 1987). The extensively mined areas surrounding the towns are characterized by eroded mounds of thinly vegetated waste coal and rock, abandoned open pits, cropfalls and other subsidence features, intermittent (losing) streambeds downstream of perennial streams, and discharges of contaminated groundwater from flooded mines. Resource and business managers recognize that economic revitalization of the region will require environmental restoration and access to land and water resources (21st Century Environment Commission, 1998). Although Shamokin Creek, Mahanoy Creek, and most other parts of the study area drain to the Susquehanna River, an area along the southeast boundary drains to the Schuylkill River (fig. 1). Water in these river basins is in great demand. Extensive, flooded underground mines have been identified as potential sources of large volumes of water needed for proposed energy-production facilities and other commercial uses (Veil and others, 2003). However, widespread usage of the mine water could affect streamflow and aquatic ecosystems of the basins that drain the coalfield. Therefore, groundwater modeling was proposed as a method for estimating present groundwater and surface-water interactions and for evaluating potential effects of large-scale water extraction and land-reclamation activities in the area.

This study, conducted by the U.S. Geological Survey (USGS) in cooperation with the Pennsylvania Department of Environmental Protection (PaDEP), the Eastern Pennsylvania Coalition for Abandoned Mine Reclamation (EPCAMR), and the Dauphin County Conservation District (DCCD), provides estimates of the water budgets and the volumes of groundwater in the abandoned underground mines of the Western
Middle Anthracite Coalfield. The study utilized available geographic, geologic, and hydrologic information to develop conceptual and numerical groundwater-flow models to describe the hydrologic framework for the mines. The Western Middle Anthracite Coalfield was studied because data were available on the locations, volumes, and quality of groundwater discharged from the underground mines; the streamflow and aquatic quality of affected streams; the depth to groundwater within the flooded mines; and the depth of mining. Proposed large-volume withdrawals of water from the underground mines and potential for decreased infiltration from proposed stream-channel modifications could affect the volumes and quality of water in the streams and discharged by the mines.

\section{Purpose and Scope}

This report describes data on the distribution and flow of surface water and groundwater and summarizes the results of computations of the water budgets and volumes for flooded underground mines on the basis of preliminary simulations of groundwater flow for the Western Middle Anthracite Coalfield. The report describes the study area, model construction, selected data used to adjust hydrologic parameters, and simulations of water budgets and groundwater/surfacewater interactions. Preliminary simulations are presented for (1) present conditions and (2) a water table lowered by pumping operations associated with thermoelectric power production. The purpose of reporting on the results of preliminary simulations is to evaluate the conceptual model and use of porous-media-flow approximations and to help guide ongoing data collection, reclamation strategies, and post-mining landuse and water-use planning for the Mahanoy and Shamokin Creek Basins. The preliminary simulations may be revised as additional details on the area hydrology become available.

\section{Previous Investigations}

Historical summaries of the surface-water and groundwater resources of the Western Middle Anthracite Coalfield study area are found in reports by Ash and others $(1949,1953 \mathrm{a}$, 1953b) and Ash and Link (1953). These reports describe the hydrological conditions during a critical period after World War II when several large underground mines were actively pumping large volumes of groundwater to avoid flooding and remain productive. Reed and others (1987) described the water resources of the study area for the post-mining, stable groundwater conditions during the mid-1970s. Growitz and others (1985), Wood (1996), Cravotta and Kirby (2004), and Cravotta (2005) described the flow and water quality of abandoned mine discharges (AMD) and associated streams in the Mahanoy and Shamokin Creek drainage basins for the post-mining conditions. Becher (1991) evaluated the longterm streamflow characteristics of Shamokin Creek near Shamokin, which was influenced by sustained discharges of AMD, and of nearby streams that were not affected by mining. 

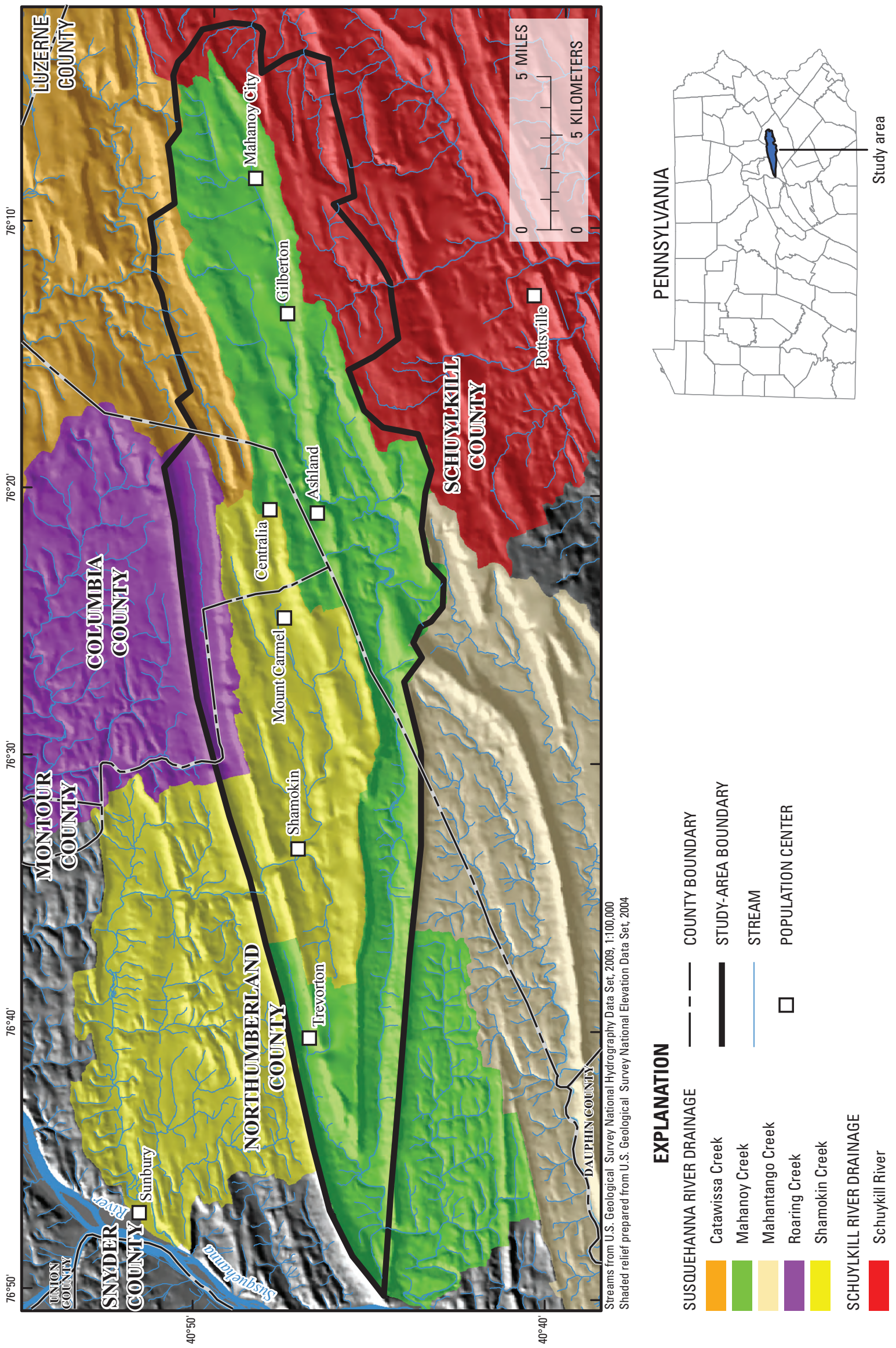

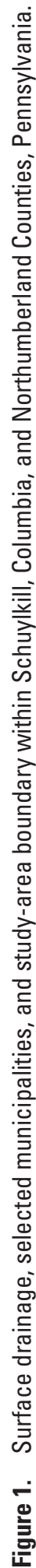


The annual base-flow yield estimates of Becher (1991) and additional computations by Risser and others (2005) generally can be interpreted to indicate annual groundwater recharge in the basin.

\section{Hydrogeologic Setting}

The Western Middle Anthracite Coalfield covers an area of approximately $120 \mathrm{mi}^{2}$ in the Appalachian Mountains section of the Ridge and Valley Physiographic Province of northeastern Pennsylvania (Berg and others, 1989; Eggleston and others, 1999). This area is characterized by northeastsouthwest trending ridges that bound narrow valleys (fig. 1). Because of their steep slopes and thin rocky soils, the ridges are sparsely developed and are largely forested. In contrast, the valleys are covered by extensive areas of barren or thinly vegetated "abandoned mine lands." Although some small towns such as Centralia were developed near mines on uplands, the larger municipalities, such as Shamokin, Mount Carmel, Ashland, and Mahanoy City, were established in the valleys (fig. 1) near large mines, railheads, or water gaps (Marsh, 1987).

Complexly folded and faulted coal-bearing sedimentary rocks underlie the study area. The Western Middle Anthracite Coalfield is a synclinal basin, or "canoe-shaped" structure, that has been subdivided by parallel faults into a series of parallel sub-basins (figs. 2, 3, and 4). Devonian and Mississippian age rocks are exposed along the ridges, whereas the coal-bearing Pennsylvanian age rocks are exposed on the valley sides and underlie the valleys (figs. 2 and 3) (Berg and others, 1980; Wood and others, 1986). In the study area, a total of 24 coalbeds within the Llewellyn and Pottsville Formations have been mined to depths exceeding 2,500 ft below land surface (Wood and others, 1986; Reed and others, 1987; Eggleston and others, 1999). The coalbeds, with average thicknesses from 2.0 to $7.4 \mathrm{ft}$ (table 1), are interbedded with shale, siltstone, sandstone, and conglomerate; limestone has not been mapped locally (Wood and others, 1986).

From about 1840 until 1966, when the last underground mine (Maysville Mine) in the study area closed, an estimated 1.6 billion short tons of anthracite had been mined from the coal basins in the Western Anthracite Middle Coalfield, leaving 3.6 to 3.9 billion short tons unmined (Reed and others, 1987; Eggleston and others, 1999). Most of the coal was removed by underground-mining methods. On average, about 20 percent of the mined coalbed consisted of shale partings, referred to as noncoal waste (table 1). Considering the quantities of coal and refuse, the total volume of mined rock was approximately 41 billion cubic feet. Reed and others (1987) estimated that 25 billion cubic feet of underground void volume was created, which, because of subsidence and backfilling, is approximately 60 percent of the total rock mined. This void volume is equivalent to excavating the entire $120-\mathrm{mi}^{2}$ area of the Western Middle Anthracite Coalfield to a depth of $7.5 \mathrm{ft}$. A large fraction of this void volume has been filled by groundwater.
Most anthracite mines were developed as large underground complexes or "collieries," where shafts and tunnels connected multiple coalbeds underlying the valleys. The underground mining was conducted by the "room-and-pillar" or "breast-and-pillar" method, with about half of the coal left to support the roof during the first stage (Reed and others, 1987; Eggleston and others, 1999). After a coalbed had been first mined, the pillars commonly were removed by retreat mining from near the mine boundary toward the mine shaft. Along the mine boundaries, unmined walls of coal, or "barrier pillars," usually were left intact to prevent explosions and fires from affecting adjacent mines and to control flooding. The intact barrier pillars acted as underground dams, preventing the flow of groundwater from adjacent mines (Ash and others, 1949; Reed and others, 1987). However, some barrier pillars had been partially mined or breached (Ash and others, 1953a).

Groundwater in the study area is recharged by infiltration of local precipitation. Because direct runoff from the mined land can be intercepted by surface openings to the mines and because vegetation tends to be sparse in areas covered by mine waste, groundwater recharge generally is greater in mined areas than in unmined areas (Ash and Link, 1953; Becher, 1991). According to Ash and Link (1953), approximately 90 percent of the water in the underground mines (active and idle) originated as general surface seepage; the remaining 10 percent originated as seepage through streambeds within the study area.

When the underground mines were active, seepage water had to be removed to prevent flooding. If the mine workings were at a higher altitude than adjacent valley bottoms, water could be removed by drainage tunnels from the mines to the adjacent valleys. In the study area, the Doutyville Tunnel, Helfenstein Locust Gap Tunnel, and Centralia Mine Tunnel convey water from mines underlying the Shamokin Creek Basin to the adjacent Mahanoy Creek Basin (Reed and others, 1987). However, many of the mines in the study area were 800 to $1,000 \mathrm{ft}$ below the valleys (Ash and others, 1949; Reed and others, 1987). Thus, pumping was required to dewater the deep workings of most mines. On average, 1,000 gal/min had to be pumped for each square mile of surface area underlain by mine workings (Ash and others, 1953b). All the large underground mines in the study area had closed by 1966 , partly because of the cost of pumping (Reed and others, 1987). After closure, the underground workings below stream levels flooded producing "mine pools" and eventually established a new water table.

When the underground mines were active, flumes were constructed to convey some streams across the mines, or the stream channels were lined, to reduce leakage and to reduce the costs of removing groundwater from the mines. Upon closure of the mines, neglected flumes and stream channels resumed leaking, and some streams were lost completely into open mine pits or other openings. Presently (2010), upper Mahanoy Creek, North Mahanoy Creek, Waste House Run, and Lost Creek in the Mahanoy Creek Basin and upper Shamokin Creek and Locust Creek in the Shamokin Creek Basin 

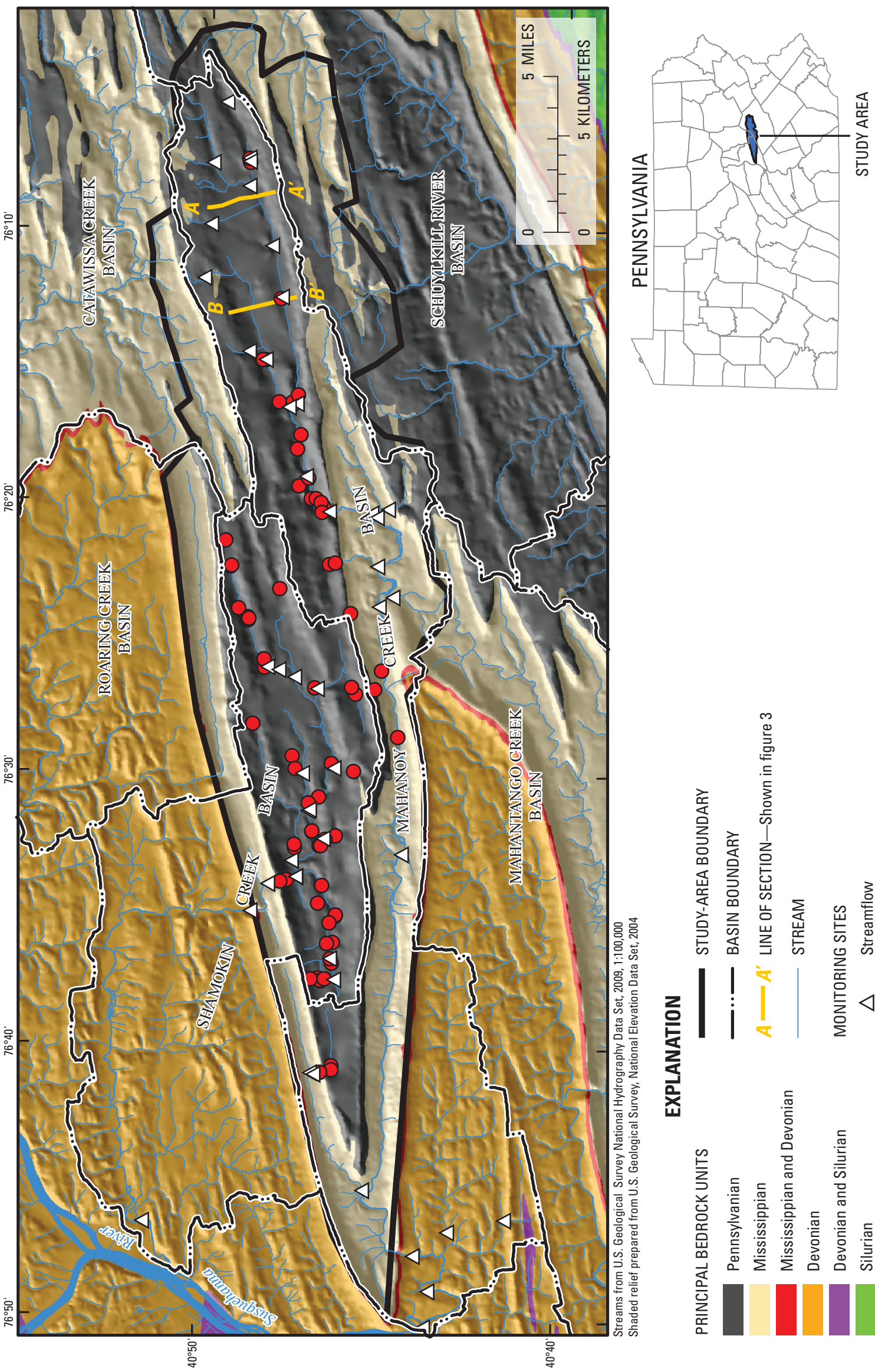

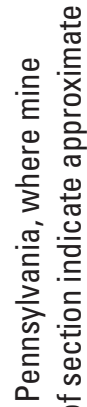

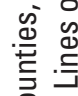

엉

즌

离

흘 증

응

ฮิ

हैं 흘

틍 힝

岂.

든 음

ज 응

站官

むँ

응

京

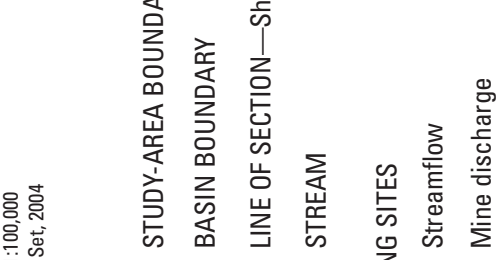

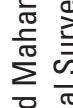

등 음

흥응

z|

的司

言吕

क वे 응

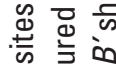

艎

ป

壱 ⿺辶冋

난

을 흘 을

저

을 竧 路

됴

ง 인

녹 은 음 

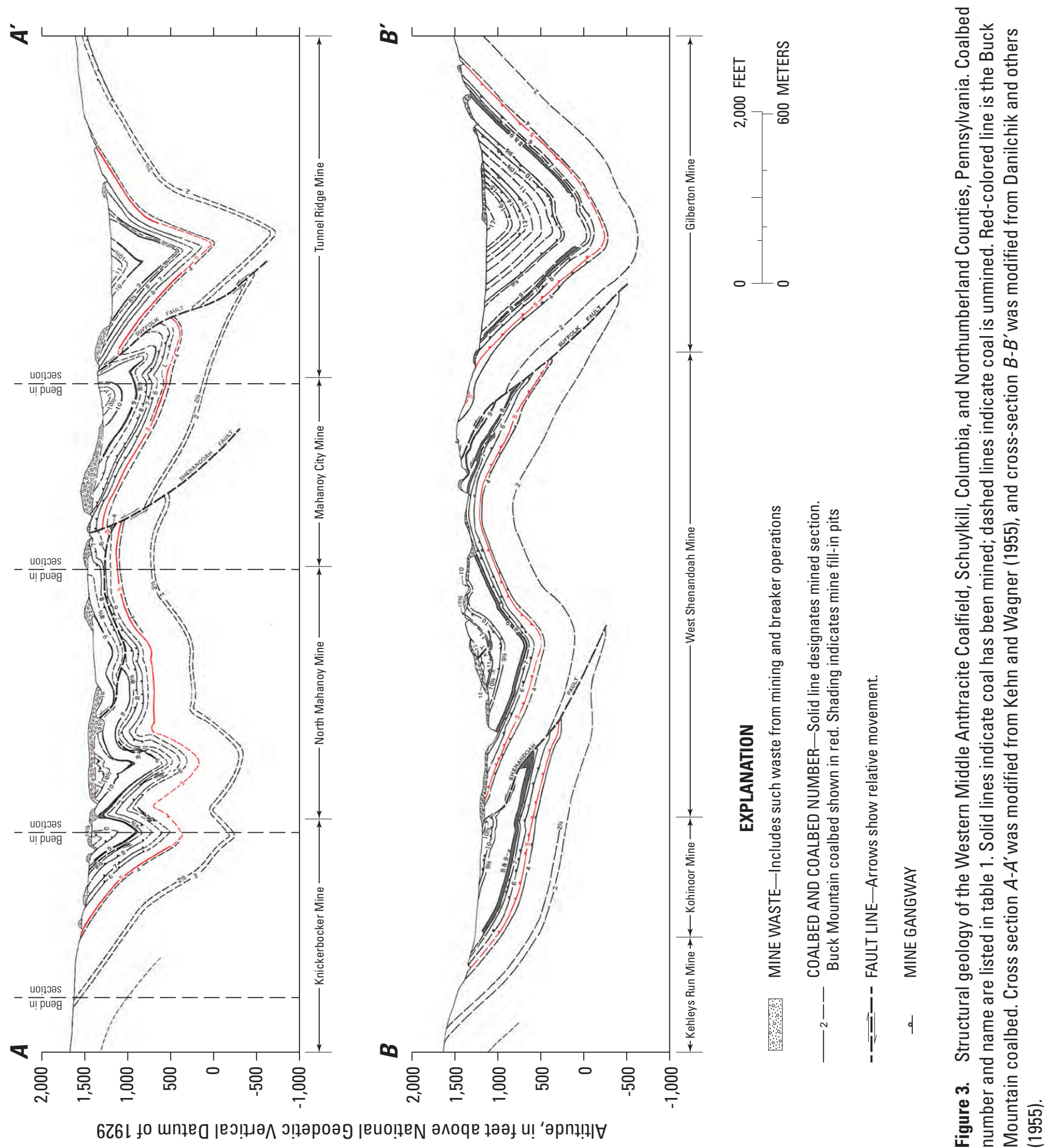

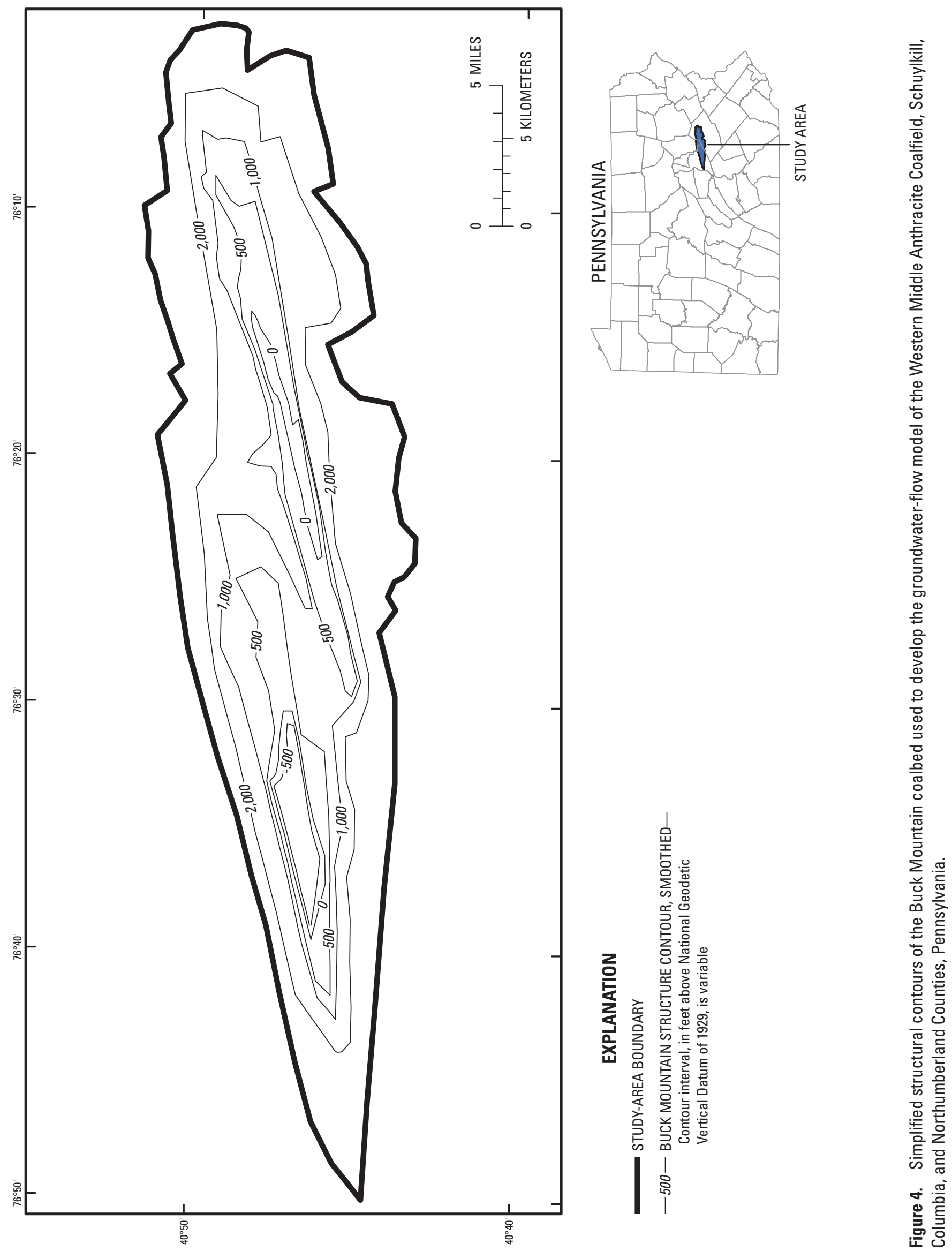
Table 1. Average thicknesses and relative altitudes of economically important coalbeds above the Buck Mountain coalbed in the Western Middle Anthracite Coalfield in eastern Pennsylvania.

[n.d., no data. Shaded rows indicate coalbeds that typically were mined, accounting for more than 90 percent of the coal production]

\begin{tabular}{|c|c|c|c|c|}
\hline $\begin{array}{l}\text { Coalbed } \\
\text { number }^{1}\end{array}$ & Coalbed name & $\begin{array}{c}\text { Average } \\
\text { thickness } \\
\text { of coalbed } \\
\text { (feet) }{ }^{2}\end{array}$ & $\begin{array}{c}\text { Relative altitude } \\
\text { above base of Buck } \\
\text { Mountain coalbed } \\
\text { (feet) }\end{array}$ & $\begin{array}{l}\text { Average percentage } \\
\text { of noncoal waste } \\
\text { in coalbed }\end{array}$ \\
\hline 20 & Rabbit Hole & 4.6 & 1,705 & n.d. \\
\hline 19 & Tunnel & 5.5 & 1,480 & n.d. \\
\hline 18 & Peach Mountain or Spahn & 6.2 & 1,410 & 16.1 \\
\hline 17 & Little Tracy & 4.4 & 1,315 & 14.3 \\
\hline 16 & Tracy & 3.7 & 1,250 & 24.8 \\
\hline 15 & Little Diamond & 4.3 & 1,150 & 20.1 \\
\hline 14 & Diamond & 4.6 & 1,065 & 23.8 \\
\hline 13 & Little Orchard & 4.8 & 945 & 22.9 \\
\hline 12 & Orchard & 5.5 & 840 & 26.2 \\
\hline 11 & Primrose & 6.2 & 705 & 15.2 \\
\hline $101 / 2$ & Rough & 4.0 & 600 & 14.0 \\
\hline 10 & Holmes & 5.9 & 460 & 12.8 \\
\hline $91 / 2$ & Four Foot & 3.7 & 435 & 19.0 \\
\hline 9 & Mammoth Top Split & 7.4 & 315 & 13.9 \\
\hline $81 / 2$ & Mammoth Middle Split & 7.0 & 285 & 10.9 \\
\hline 8 & Mamoth Bottom Split & 6.4 & 270 & 15.4 \\
\hline 7 & Skidmore & 4.6 & 190 & 25.4 \\
\hline 6 & Seven Foot & 4.0 & 65 & 25.9 \\
\hline 5 & Buck Mountain & 6.4 & 0 & 22.1 \\
\hline 4 & Coal D (Little Buck Mountain) & 2.3 & -110 & 22.8 \\
\hline 3 & Coal C (Whites) & 2.6 & -160 & 8.5 \\
\hline- & Coal B & 2.0 & -260 & n.d. \\
\hline $21 / 2$ & Coal A & 3.8 & -355 & 16.6 \\
\hline 2 & Lykens Valley no. 4 & 4.4 & -485 & 19.1 \\
\hline
\end{tabular}

${ }^{1}$ Coalbed numbers and names adapted from U.S. Geological Survey coal-investigation maps (Arndt and others, 1963a, 1963b; Danilchik and others, 1955, 1962; Haley and others, 1953, 1954; Kehn and Wagner, 1955; Maxwell and Rothrock, 1955; Rothrock and others, 1950, 1951a, 1951b, 1953).

${ }^{2}$ Average coalbed thickness and altitudes adapted from Eggleston and others (1999).

${ }^{3}$ Average percentage of noncoal refuse computed from tables in USGS coal-investigation maps.

lose all or most of their flow to underground mines during dry periods (Cravotta and Kirby, 2004; Cravotta, 2005).

In lower reaches of the basin, local streams commonly gain groundwater discharged from the flooded mines. This groundwater, generally referred to as AMD, is an important component of base flow to the local streams (Becher, 1991). The AMD emanates from mine openings, fractures in stream channels, and other topographically low points overlying the mine complexes. Because the AMD is widely contaminated with dissolved sulfate, iron, and manganese that originated from the weathering of rocks exposed by mining, the water quality in streams within and downstream of the mined areas is degraded (Cravotta and Kirby, 2004; Cravotta, 2005).

Despite its degraded quality, the mine-pool water has been utilized locally since the early 1980 s for thermoelectric power generation and associated coal preparation. According to Veil and others (2003), the three largest users of mine-pool water in the basin are Gilberton Power Company ( $950 \mathrm{gal} / \mathrm{min}$ from the Gilberton Mine), Schuylkill Energy Resources $(1,100 \mathrm{gal} / \mathrm{min}$ from the Maple Hill Mine), and Wheelabrator Frackville Energy Co. (600 gal/min from the Morea Mine). These users must treat the groundwater to remove 
dissolved iron and other contaminants. Although some of the water is recycled or recharged back to the mine pool, part is evaporated and lost from the basin. Other industries have expressed interest in additional consumptive use of the minepool water (Veil and others, 2003; Susquehanna River Basin Commission, 2005).

\section{Streamflow and Groundwater Relations}

To document streamflow and groundwater relations and to update previous water-resources assessments of the study area by Ash and others (1949) and Reed and others (1987), the most recent available data on streamflow, AMD discharges, and mine-pool water levels were compiled and evaluated for the current study. The spatial relations among streams, AMD discharges, and mine-pool water levels within sub-basins in the study area were examined using maps and a geographic information system (GIS).

\section{Streamflow and Mine-Discharge Data}

Continuous streamflow was measured by USGS for Shamokin Creek near Shamokin during 1953-1982 (Becher, 1991). This long-term, continuous record immediately downstream from the mined part of the basin is useful to estimate groundwater recharge (Risser and others, 2005); however, continuous streamflow data were not available elsewhere in the study area. Flow rates of AMD sources were measured monthly by USGS at selected locations in the study area during 1975-1977 (Growitz and others, 1985; Reed and others, 1987). However, because rainfall during 1975-1977 was nearly 20 percent higher than average for the area (fig. 5), many of the reported AMD flow rates during this period were a factor of two or more greater than values measured at the same sites during 1991 (Wood, 1996) and 1999-2001 (Cravotta and Kirby, 2004; Cravotta, 2005).

For this study, the synoptic data on streamflow and mine-discharge rates that were collected by USGS during stable base-flow conditions in 1999-2001 at 49 stream sites and 78 AMD sites in the Shamokin and Mahanoy Creek Basins (Cravotta and Kirby, 2004; Cravotta, 2005) were used to indicate spatial variability within the area. For each stream basin, one round of measurements over a 2-day period was conducted during low base-flow conditions, and a second round was conducted during high base-flow conditions. The location of each site was determined by global positioning system (GPS), and the surface altitude and surface drainage area upstream from each site were determined using USGS topographic quadrangle maps or the USGS StreamStats web application (U.S. Geological Survey, 2009). The site locations are shown in figure 2; site descriptions are given in tables 2 and 3. (Table 3 at end of report.)

To estimate the long-term average base-flow conditions at each site for this study, the average of the low and high base-flow measurements in 2000-2001 for the Mahanoy Creek Basin was used, and only the high base-flow measurement at each site in 2000 for the Shamokin Creek Basin was used. The low base-flow measurements for the Shamokin Creek Basin were conducted during near-drought conditions in 1999 (fig. 5). However, streamflow of Shamokin Creek near Shamokin during the high base-flow measurements in 2000 approximated the long-term average (Cravotta and Kirby, 2004). To normalize the streamflow values among sub-basins within the entire study area, the base-flow yield was computed by dividing the estimated streamflow for each site by its upstream surface drainage area (table 2).

The estimated base-flow yields for the sub-basins in the study area exhibited a wide range of values ( 0 to $81 \mathrm{in} / \mathrm{yr}$ ) (table 2) compared to the average base-flow yields reported for continuously gaged streams throughout Pennsylvania (6 to $27 \mathrm{in} / \mathrm{yr}$ ) (Risser and others, 2005) and compared to the long-term records of annual precipitation for the area (30 to $74 \mathrm{in} / \mathrm{yr}$ ) (fig. 5). Locally anomalous base-flow yields (fig. 6) result from substantial streamflow losses and gains associated with the underground mines that extend beneath local surface drainage divides (fig. 7). The sub-basins that exhibited low yields (less than or equal to $9 \mathrm{in} / \mathrm{yr}$ ) were in the headwaters areas of Shamokin and Mahanoy Creeks (figs. 5 and 6). With the exception of Crab Run (site S21), which was diverted for irrigation, the sub-basins with low yields lost streamflow by leakage to, or capture by, underground mines. With the exception of Rattling Run (site S18), the sub-basins with high yields ( 26 to $81 \mathrm{in} / \mathrm{yr}$ ) gained base flow from one or more large sources of AMD. Downstream from the sub-basin areas underlain by mines, because the losses and gains in the mined area cancelled out over the larger basin, the streamflow yields were normal compared to other gaged streams in Pennsylvania.

Despite drier than normal rainfall conditions in 19992001 (fig. 5), the synoptic data of 1999-2001 are considered to represent average steady-state base flow for the area. The base-flow yields estimated for the lower and middle reaches of Shamokin Creek (18.0 to $22.6 \mathrm{in} / \mathrm{yr}$ ) and the lower reaches of Mahanoy Creek (17.0 to $19.7 \mathrm{in} / \mathrm{yr}$ ) (table 2) compare well with the average base-flow yield of $17.6 \mathrm{in} / \mathrm{yr}$ ( 8.1 to $27.8 \mathrm{in} / \mathrm{yr}$ during 1955-1982) computed by Becher (1991) and averages of 18.8 and $21.0 \mathrm{in} / \mathrm{yr}$ computed by Risser and others $(2005)^{5}$ for Shamokin Creek near Shamokin.

\footnotetext{
${ }^{5}$ Risser and others (2005) used two automated streamflow-hydrograph-analysis methods-PART and RORA (Rutledge, 1998) - to compute groundwater recharge from the long-term streamflow record at Shamokin Creek at Shamokin (01554500). The value of $18.8 \mathrm{in} / \mathrm{yr}$ was estimated with the computer model, PART, whereas the value of $21.0 \mathrm{in} / \mathrm{yr}$ was estimated using RORA.
} 


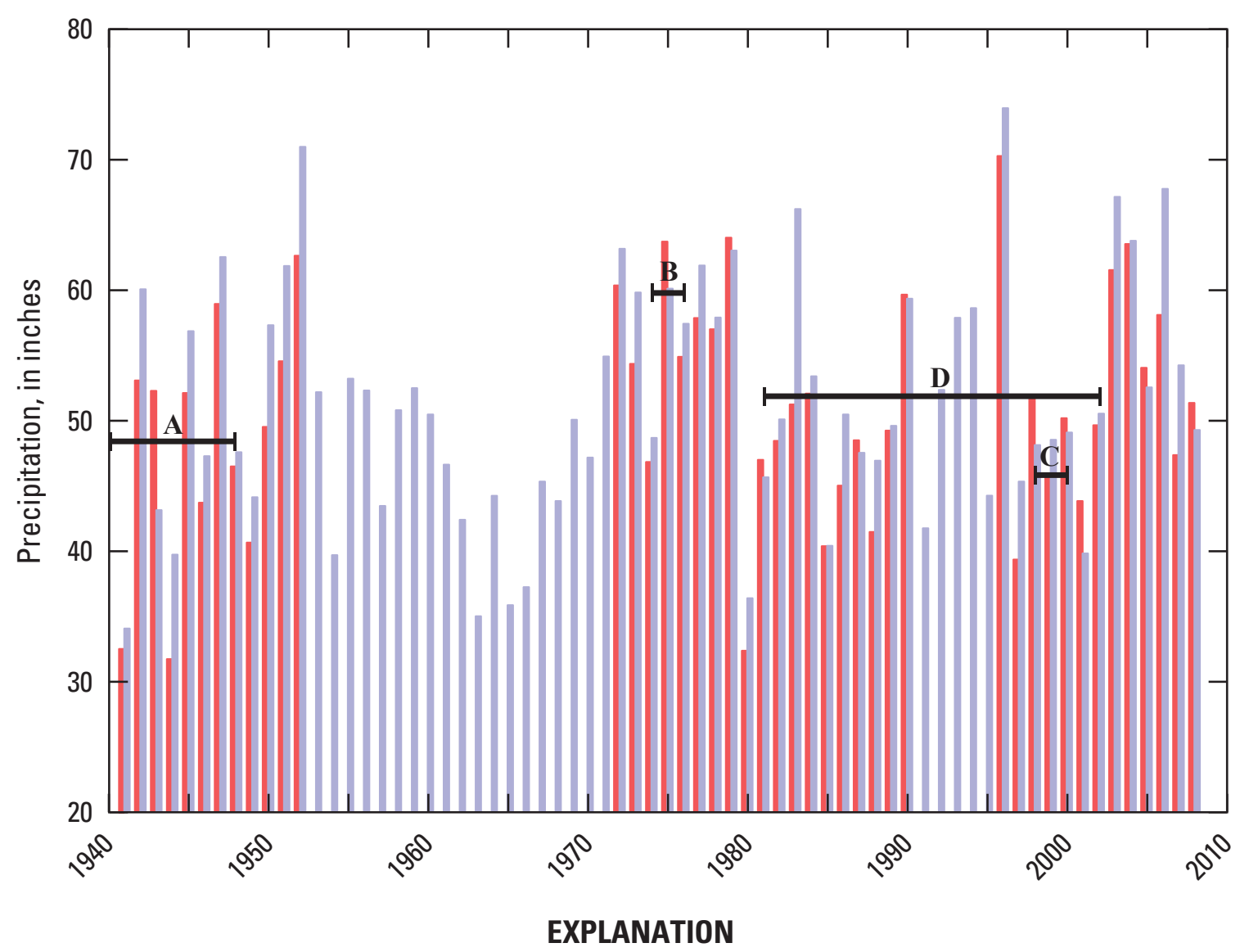

\author{
ANNUAL PRECIPITATION \\ Mahanoy City \\ - Tamaqua \\ AVERAGE PRECIPITATION AT TAMAQUA, PA, OVER INVESTIGATION
PERIOD—Endpoints denotes start and end of investigation period \\ A Ash and others, 1949 \\ B Growitz and others, 1985; Reed and others, 1987 \\ C Cravotta and Kirby, 2004; Cravotta, 2005 \\ D This report
}

Figure 5. Total annual precipitation during 1941 to 2008 for Mahanoy City and Tamaqua, Pennsylvania. Data for Mahanoy City during 1972-2008 and Tamaqua are from National Climatic Data Center (2010). Data for Mahanoy City during 1941-1952 are from Ash and Link (1953). Horizontal line segments indicate the average annual precipitation at Tamaqua for time periods of previous investigations by Ash and others (1949), Growitz and others (1985), Reed and others (1987), Cravotta and Kirby (2004), and Cravotta (2005), plus unpublished data collected by the Pennsylvania Department of Environmental Protection (this report). 
Table 2. Site descriptions and estimated streamflow yields for surface drainage sub-basins within Shamokin and Mahanoy Creek Basins, Schuylkill, Columbia, and Northumberland Counties, Pennsylvania, 1999-2001

[USGS, U.S. Geological Survey; $\mathrm{mi}^{2}$, square miles; $\mathrm{ft}^{3} / \mathrm{s}$, cubic feet per second; in/yr, inches per year]

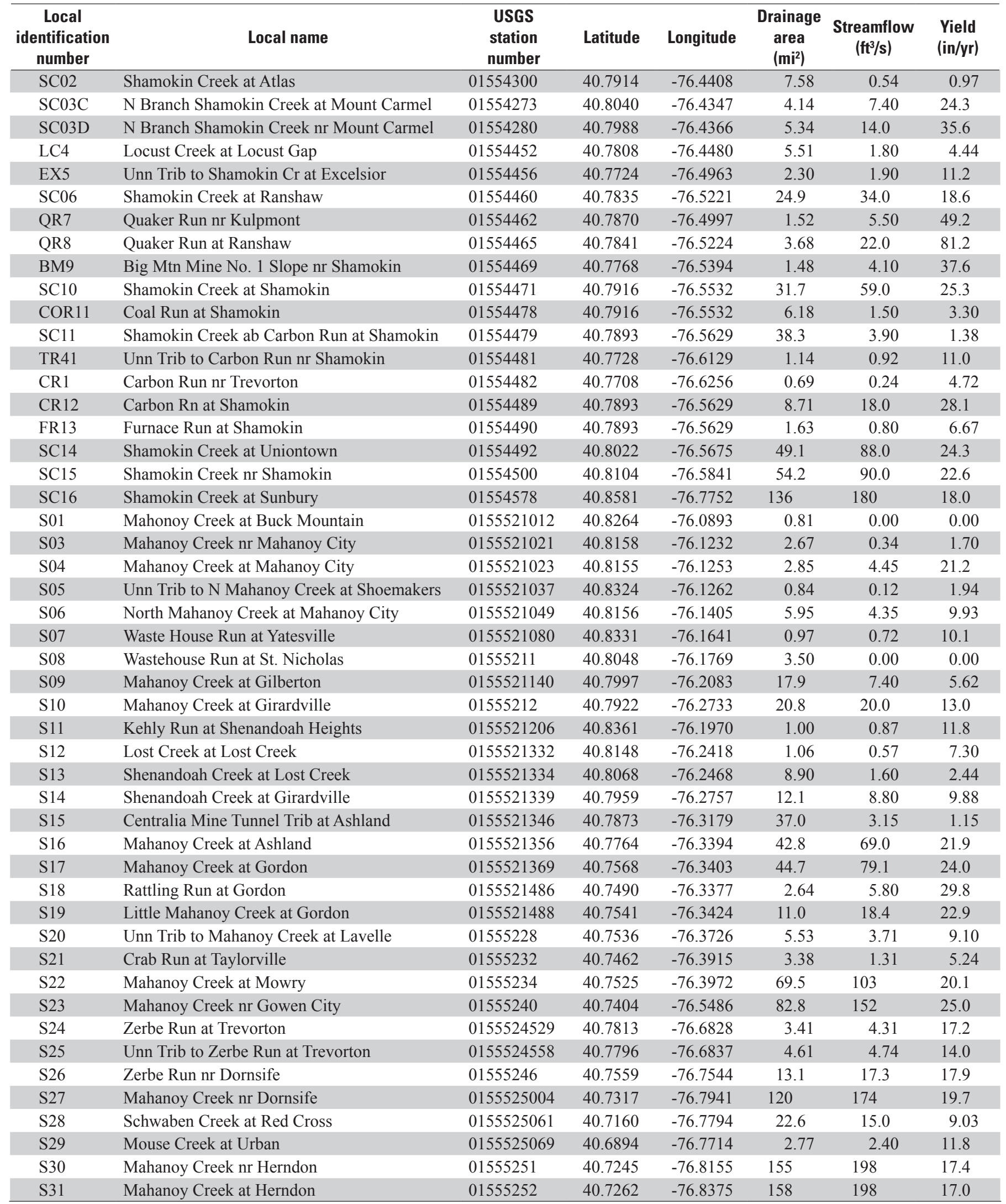



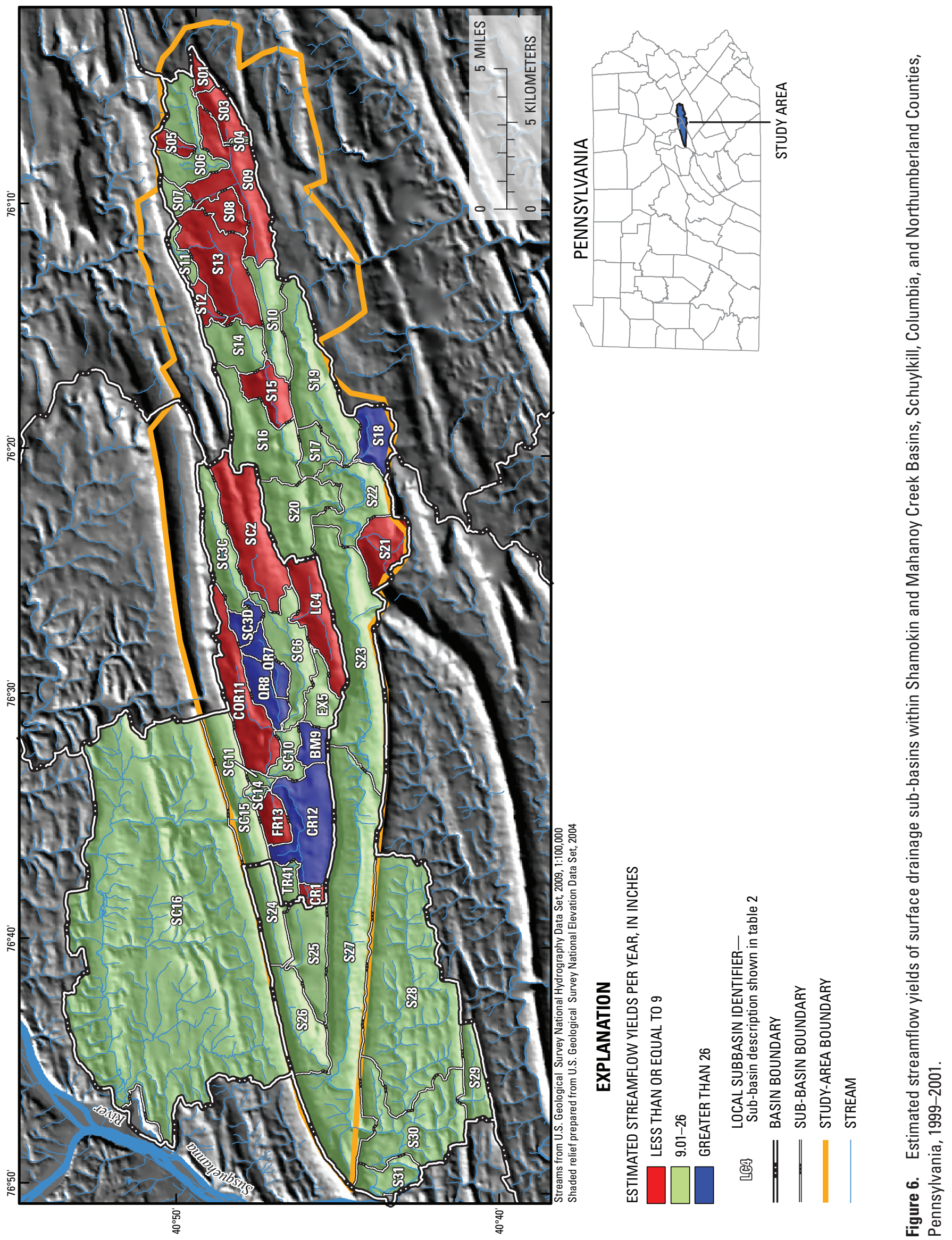

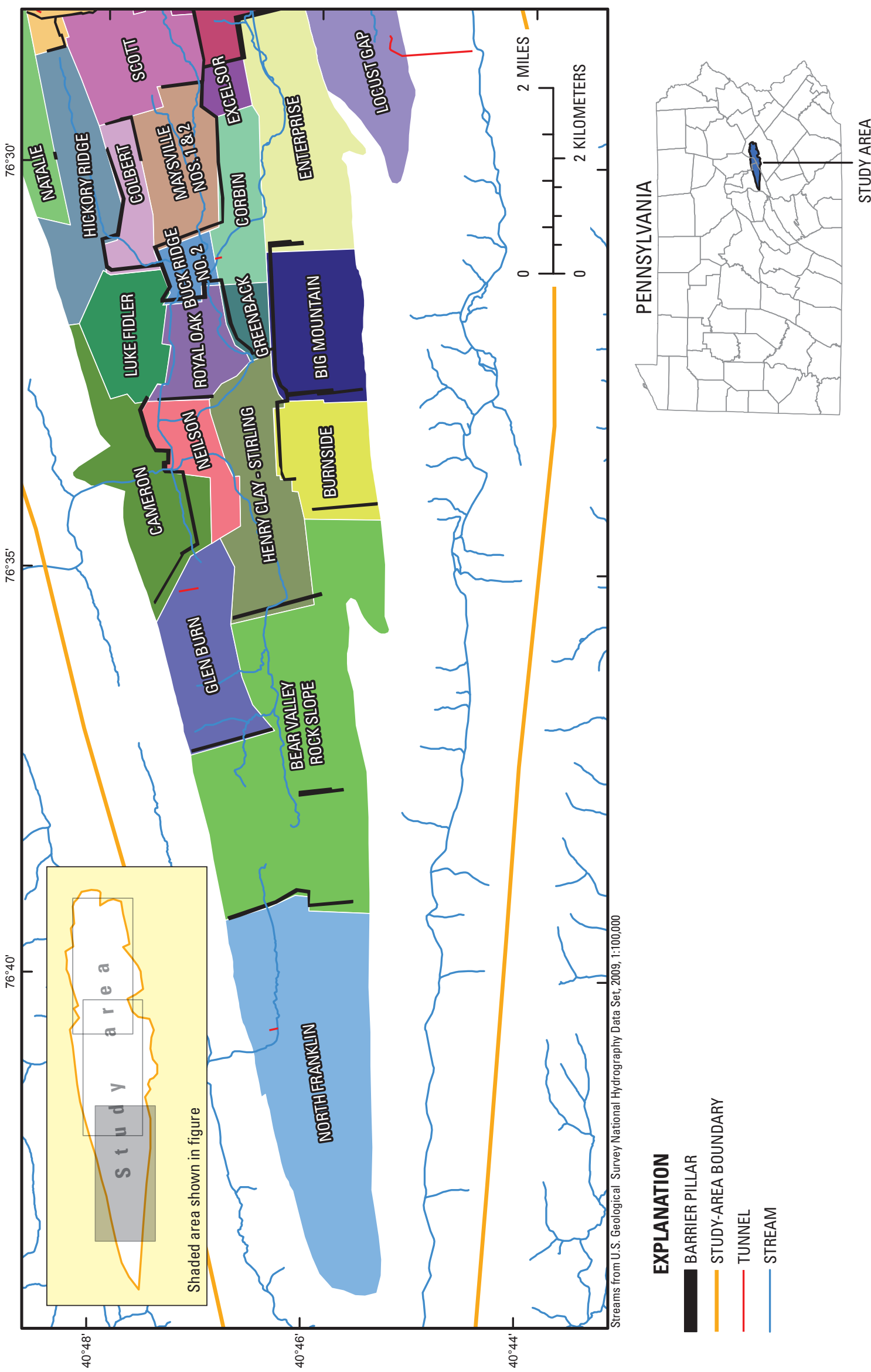

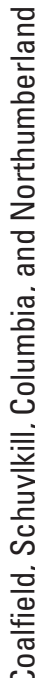

$\stackrel{0}{ \pm}$

冚 冚

읗

을 은

$\sum_{i}$

क्ष

我

至

站

艝

站哭

울

के 등

㲔

흔으

竞

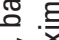

혼

흥

증 음

은 흐

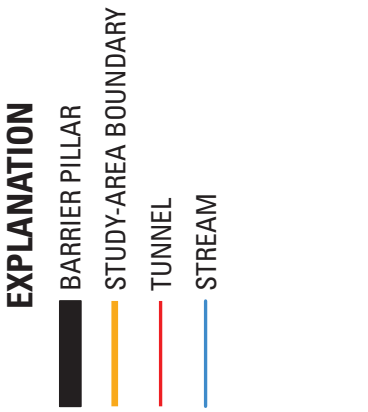

능

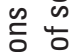

윯 \&

产

등

高

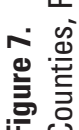



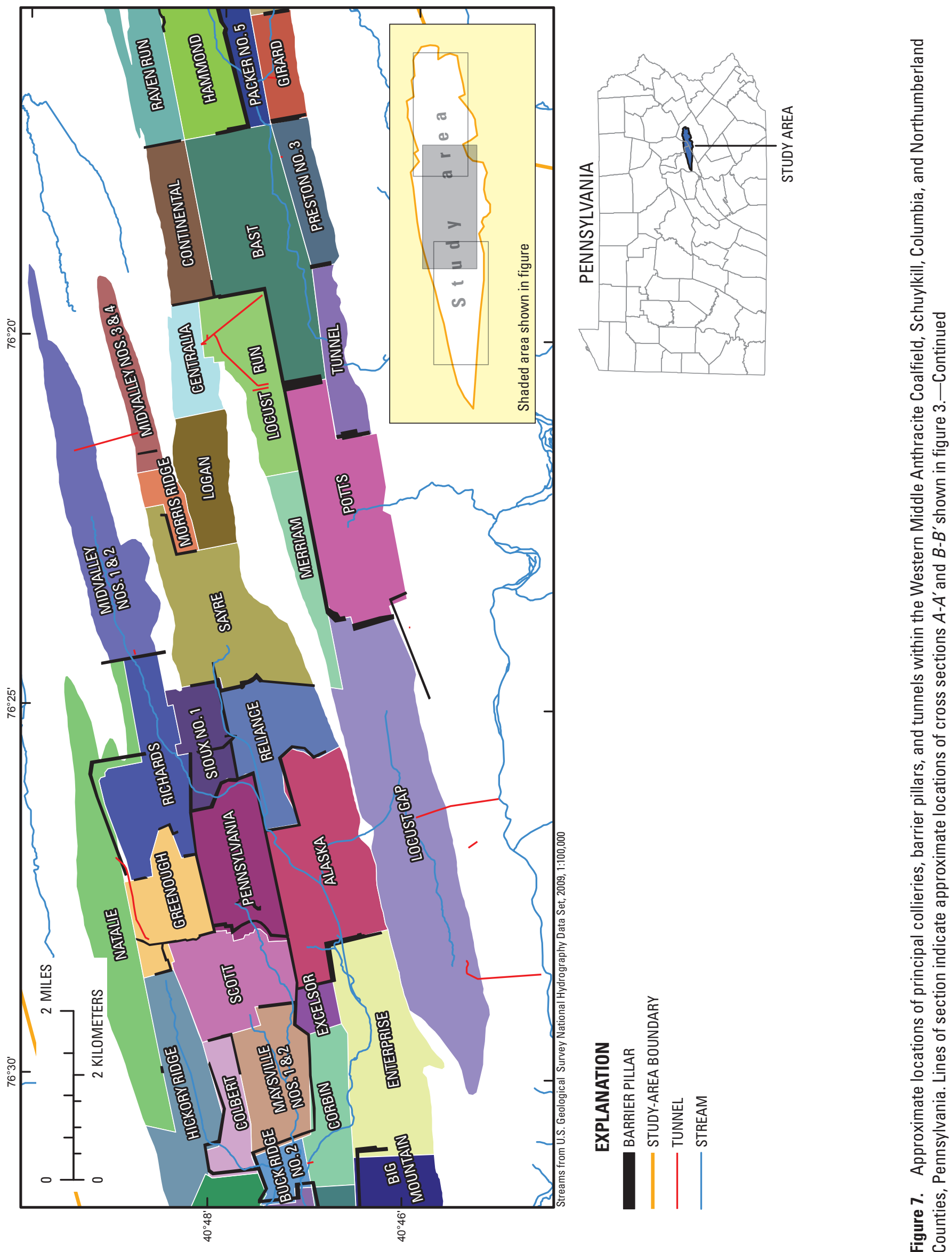

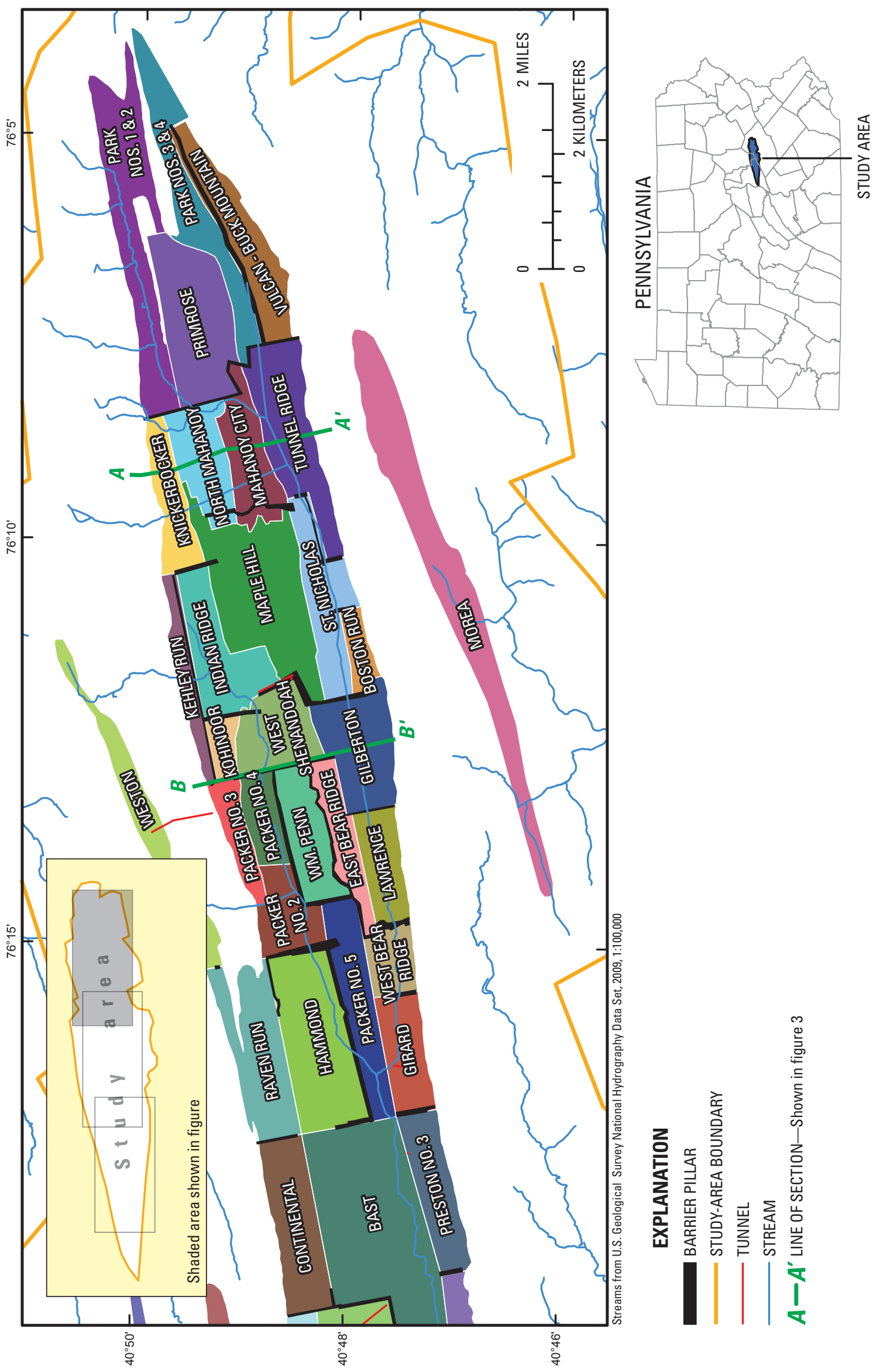

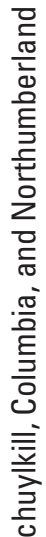

它

(1)

․․․

坖

읗

$\sum$ s

它

ฏ 든

这

产 돈

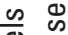

怘哭

을

के

言

흔

离

को

은 흥

言

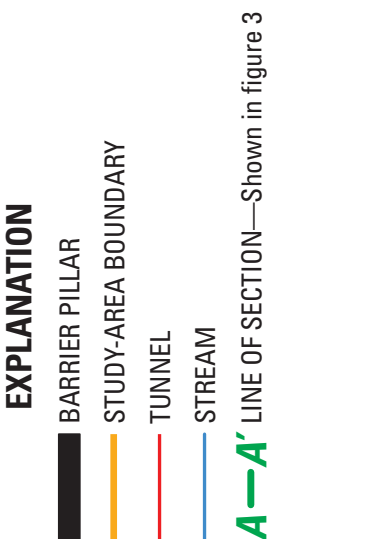

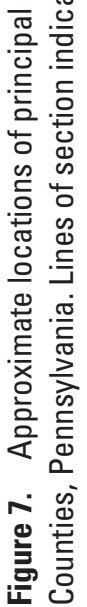




\section{Mine-Pool Water-Level Data}

A total of 69 named underground mines or collieries covering an estimated area of more than $85 \mathrm{mi}^{2}$ were developed within the Western Middle Anthracite Coalfield, with individual areas ranging from $0.20 \mathrm{mi}^{2}$ for the Kohinoor Mine to $5.52 \mathrm{mi}^{2}$ for the Bear Valley Rock Slope (table 4, fig. 7). The bottom altitude of the mines, obtained from the lowest gangway details shown on mine maps, ranged from $-587 \mathrm{ft}$ for the Luke Fiddler Mine to $983 \mathrm{ft}$ for the Natalie Mine (table 4). The approximate locations of colliery boundaries and associated barrier pillars and tunnels were obtained from unpublished and published maps (Ash and others, 1949, 1953a; Gannett Fleming Corddry and Carpenter, Inc., 1972; Sanders $\&$ Thomas, Inc., 1975; Reed and others, 1987) and used to create GIS files. The GIS and associated digital files on the mine locations were only approximate because the source maps lacked coordinates and relevant projection information.

To account for spatial variations in the depth of mined coal and the location of coalbeds relative to the water table within the mines, the structure contour of the Buck Mountain coalbed was digitized from published USGS coal-investigation maps (Arndt and others, 1963a, 1963b; Danilchik and others, 1955, 1962; Haley and others, 1953, 1954; Kehn and Wagner, 1955; Maxwell and Rothrock, 1955; Rothrock and others, 1950, 1951a, 1951b, 1953). Because of overturned folds, faulting, and other geologic complexities (fig. 3), the structure-contour base was generalized and simplified (fig. 4). The generalized structure contour of the Buck Mountain coalbed retained the regional geometry of the coal basin and was used in this study along with values for thickness and relative altitudes of other coal beds (table 2) and the maximum depth of mining (table 4) in the study area to estimate the approximate volume of coal and associated rock that had been mined.

Unpublished water-level data, measured by PaDEP during 1982-2003 for 46 boreholes in mine pools of the Western Middle Anthracite Coalfield (table 5, at end of report; fig. 7), were used to indicate the potential for the collieries to be flooded and interconnected, the potential directions of groundwater flow, and, ultimately, the volumes of water flowing and stored within the mine pools (water budget). Because of the extended period and variable seasons of the measurements, the average water levels for 1982-2003 are considered to represent steady-state groundwater levels. The measurements, which were conducted quarterly during 1982-2000 and annually during 2001-03, represent a wide range of rainfall and associated hydrologic conditions (fig. 5). Although a few of the boreholes exhibited stable water levels, with minimum and maximum values about $+/-5 \mathrm{ft}$ of the average, most exhibited variations in water levels of $+/-10$ to $+/-30 \mathrm{ft}$ of the average (table 5). Flowing boreholes are indicated by a maximum groundwater altitude equal to the borehole surface altitude. Generally, the most stable water levels were associated with flowing boreholes within the valleys, whereas the least stable water levels were associated with boreholes in mines along the perimeter of the study area. Reed and others (1987) measured the water level and water quality in most of these boreholes during 1975-77. Despite higher rainfall conditions during this earlier study (fig. 5), the range of water levels reported by Reed and others (1987) was similar to that recorded for the same boreholes in 1982-2003.

\section{Multicolliery Unit Concept}

Because all workings within a mine are connected to the mine shaft, directly or by horizontal tunnels, the waterlevel altitudes tend to be uniform within a flooded colliery. Where barrier pillars are intact, adjacent collieries can form distinctive mine pools with water levels that differ by many tens of feet on either side of the barrier. However, if a barrier pillar between adjacent collieries was breached, and water can flow readily between the collieries, the water levels in these adjoining mines tend to be uniform. Where multiple collieries are interconnected, discharge is commonly from a single AMD source at a topographically low point within this "multicolliery" unit (MCU). Generally, the upper limit of the water level in a MCU would be controlled by the altitudes of breaches in barrier pillars or the approximate surface altitude for the primary AMD outlet in the downgradient direction.

The 69 mapped collieries in the study area were grouped as 17 named mine pools or MCUs (table 6, fig. 8) on the basis of previously identified mine pools and barrier pillars (Ash and others, 1949, 1953a) and on the basis of the uniformity of recently measured groundwater levels and the relative flow rates of primary AMD outlets. Using an approach analogous to the computation of the base-flow yield, where streamflow was divided by the upstream drainage area, an approximate discharge rate for each MCU was computed by multiplying the area of the MCU by a specified recharge rate of $18.0 \mathrm{in} / \mathrm{yr}$ (table 6). Given this recharge over the total area of the mines, the corresponding discharge would be $114 \mathrm{ft}^{3} / \mathrm{s}$ or $51,300 \mathrm{gal} / \mathrm{min}$, with estimated discharge ranging from $0.92 \mathrm{ft}^{3} / \mathrm{s}$ for the Preston MCU to $17.85 \mathrm{ft}^{3} / \mathrm{s}$ for the Scott MCU. This computation assumes that all the water discharging from the mines originates as recharge within the MCU area and is proportional to the area; it excludes possible inflows by stream leakage to the MCU from outside the area and possible flow to or from adjacent MCUs. The computed discharge rate for 14 of the 17 MCUs was within the range of the low and high values measured during 1999-2001 for the AMD sources within or associated with the MCU area (table 6). This general agreement supports the MCU concept. The computed discharge for the Girard MCU was smaller than measured, possibly because flow to the Girardville Seepage, the primary AMD outlet, originates from outside the MCU. In contrast, the computed discharges for the Packer MCU and Potts \& Tunnel Mine MCU were slightly larger than the measured values because some of the AMD associated with these units was not measured. For example, Cravotta (2005) suggested that unsampled discharge from the Tunnel Mine was likely to enter the streambed of Mahanoy Creek, thus accounting for 
Table 4. Name, year of closure, estimated area, and altitude of deepest mining of collieries in the Western Middle Anthracite Coalfield, Schuylkill, Columbia, and Northumberland Counties, Pennsylvania.

[ft, feet above National Geodetic Vertical Datum of 1929; $\mathrm{mi}^{2}$, square miles; n.d., no data]

\begin{tabular}{|c|c|c|c|c|c|c|c|c|c|}
\hline Colliery name & $\begin{array}{c}\text { Year } \\
\text { closed }^{1}\end{array}$ & $\begin{array}{l}\text { Altitude } \\
\text { of } \\
\text { deepest } \\
\text { mining } \\
\text { (ft) }\end{array}$ & $\begin{array}{l}\text { Area } \\
\left(\mathrm{mi}^{2}\right)\end{array}$ & $\begin{array}{l}\text { Multicolliery unit } \\
\text { (MCU) name }\end{array}$ & Colliery name & $\begin{array}{c}\text { Year } \\
\text { closed }^{1}\end{array}$ & $\begin{array}{c}\text { Altitude } \\
\text { of } \\
\text { deepest } \\
\text { mining } \\
\text { (ft) }\end{array}$ & $\begin{array}{l}\text { Area } \\
\left(\mathrm{mi}^{2}\right)\end{array}$ & $\begin{array}{l}\text { Multicolliery unit } \\
\text { (MCU) name }\end{array}$ \\
\hline Park Nos. $1 \& 2$ & 1953 & 891 & 1.45 & Vulcan & Potts & 1934 & 9 & 2.39 & Potts \& Tunnel \\
\hline Park Nos. $3 \& 4$ & n.d. & 855 & 1.09 & Vulcan & Morris Ridge & n.d. & 828 & 0.35 & Scott \\
\hline Primrose & n.d. & 616 & 1.22 & Vulcan & Sayre & n.d. & 574 & 2.12 & Scott \\
\hline Vulcan-Buck Mountain & 1932 & 349 & 0.91 & Vulcan & Sioux No. 1 & n.d. & 419 & 0.78 & Scott \\
\hline North Mahanoy & n.d. & 833 & 0.66 & Packer & Pennsylvania & n.d. & 79 & 1.47 & Scott \\
\hline Knickerbocker & 1953 & 534 & 0.53 & Packer & Richards & n.d. & 581 & 1.64 & Scott \\
\hline Maple Hill & 1954 & 278 & 1.65 & Packer & Natalie & 1929 & 983 & 2.55 & Scott \\
\hline Mahanoy City & 1953 & 515 & 0.68 & Packer & Greenough & 1926 & 587 & 1.04 & Scott \\
\hline Kehley Run & n.d. & 546 & 0.36 & Packer & Scott & 1928 & -62 & 1.38 & Scott \\
\hline Indian Ridge & 1932 & 661 & 0.85 & Packer & Germantown (Locust Run) & 1960 & 727 & 1.34 & Locust Gap \\
\hline Kohinoor & 1953 & 232 & 0.20 & Packer & Germantown (Merriam) & n.d. & 574 & 0.71 & Locust Gap \\
\hline West Shenandoah & n.d. & 180 & 0.71 & Packer & Locust Gap & 1955 & 371 & 4.87 & Locust Gap \\
\hline Wm. Penn & 1946 & 104 & 0.67 & Packer & Reliance & 1953 & -93 & 1.35 & Maysville-Corbin \\
\hline Packer No. 4 & n.d. & 168 & 0.39 & Packer & Alaska & 1954 & 474 & 2.48 & Maysville-Corbin \\
\hline Packer No. 3 & n.d. & 335 & 0.34 & Packer & Enterprise & 1935 & 777 & 2.33 & Maysville-Corbin \\
\hline Packer No. 2 & n.d. & 218 & 0.53 & Packer & Excelsor & 1935 & 777 & 0.27 & Maysville-Corbin \\
\hline Packer No. 5 & 1959 & 74 & 0.83 & Packer & Corbin & n.d. & 324 & 0.92 & Maysville-Corbin \\
\hline Hammond & 1954 & -78 & 1.40 & Packer & Buck Ridge No. 2 & n.d. & 258 & 0.36 & Maysville-Corbin \\
\hline W. Bear Ridge & 1938 & 131 & 0.37 & Girard & Buck Ridge No. 1 & 1900 & 53 & 0.35 & Maysville-Corbin \\
\hline Girard & n.d. & 444 & 0.59 & Girard & Maysville Nos. $1 \& 2$ & 1966 & 333 & 1.23 & Maysville-Corbin \\
\hline Tunnel Ridge & 1931 & 370 & 1.09 & Gilberton & Hickory Ridge & 1929 & 132 & 1.51 & Cameron \\
\hline St. Nicholas & 1928 & 128 & 0.79 & Gilberton & Luke Fidler & 1929 & -587 & 1.05 & Cameron \\
\hline Boston Run & n.d. & 158 & 0.22 & Gilberton & Colbert & 1929 & 203 & 0.64 & Cameron \\
\hline Gilberton & 1938 & -100 & 0.90 & Gilberton & Neilson & 1900 & -578 & 0.76 & Cameron \\
\hline Lawrence & 1938 & 130 & 0.53 & Gilberton & Glen Burn & n.d. & 139 & 1.57 & Cameron \\
\hline East Bear Ridge & n.d. & 674 & 0.49 & Gilberton & Cameron & 1928 & -351 & 1.73 & Cameron \\
\hline Weston & 1959 & 438 & 0.87 & Weston & Big Mountain & n.d. & 305 & 1.62 & Big Mountain \\
\hline Continental & n.d. & 741 & 0.94 & Centralia & Burnside & 1932 & 184 & 1.22 & Sterling \\
\hline Centralia & n.d. & 701 & 0.64 & Centralia & Bear Valley Rock Slope & 1939 & 394 & 5.52 & Sterling \\
\hline Logan & n.d. & 914 & 0.92 & Centralia & Henry Clay-Stirling & n.d. & 19 & 1.87 & Sterling \\
\hline Bast & 1934 & 23 & 2.77 & Bast & Royal Oak & 1906 & 616 & 0.79 & Sterling \\
\hline Preston No. 3 & n.d. & 265 & 0.69 & Preston & North Franklin & 1929 & 308 & 4.68 & North Franklin \\
\hline Midvalley Nos. $3 \& 4$ & n.d. & 953 & 0.67 & Midvalley & Morea & n.d. & n.d. & 1.92 & Morea \\
\hline Midvalley Nos. $1 \& 2$ & n.d. & 622 & 2.22 & Midvalley & Raven Run & n.d. & 982 & 1.04 & Raven Run \\
\hline Tunnel & 1891 & 191 & 0.66 & Potts \& Tunnel & & & & & \\
\hline
\end{tabular}

${ }^{1}$ Year of closure reported by Reed and others (1987). All mines closed by 1966, including those where the year is indicated as "n.d." 
Table 6. Names, areas, estimated discharge, and measured discharge from multicolliery hydrologic units in the Western Middle Anthracite Coalfield in eastern Pennsylvania.

[MCU, multicolliery unit; AMD, abandoned mine discharge; $\mathrm{mi}^{2}$, square miles; $\mathrm{ft}^{3} / \mathrm{s}$, cubic feet per second]

\begin{tabular}{|c|c|c|c|c|c|}
\hline \multirow[t]{2}{*}{ MCU name } & \multirow{2}{*}{$\begin{array}{l}\text { MCU area } \\
\qquad\left(\mathrm{mi}^{2}\right)\end{array}$} & \multirow{2}{*}{$\begin{array}{c}\text { Estimated } \\
\text { discharge }^{1} \\
\left(\mathrm{ft}^{3} / \mathrm{s}\right)\end{array}$} & \multicolumn{2}{|c|}{$\begin{array}{l}\text { Measured discharge } \\
\left(\mathrm{ft}^{3} / \mathrm{s}\right)\end{array}$} & \multirow[t]{2}{*}{ AMD site identification number ${ }^{3}$} \\
\hline & & & Minimum & Maximum & \\
\hline Vulcan & 4.67 & 6.19 & 2.64 & 14.07 & $\mathrm{M} 03+\mathrm{M} 02$ \\
\hline Packer $^{3}$ & 11.69 & 15.49 & 8.76 & 15.06 & $\mathrm{M} 05+\mathrm{M} 07+\mathrm{M} 12+\mathrm{M} 13+\mathrm{M} 08+\mathrm{M} 09$ \\
\hline Gilberton & 4.02 & 5.33 & 0 & 10.83 & M04 \\
\hline Centralia & 2.49 & 3.3 & 2.43 & 3.86 & M19 \\
\hline Bast & 2.77 & 3.67 & 2.7 & 6.90 & $\mathrm{M} 21+\mathrm{M} 20+\mathrm{M} 18$ \\
\hline Preston & 0.69 & 0.92 & 0.67 & 2.23 & M17 \\
\hline Scott & 11.35 & 15.04 & 9.43 & 25.66 & SR19+SR06+SR31+SR55 \\
\hline Locust Gap & 6.91 & 9.16 & 8.28 & 20.72 & M29+M31 \\
\hline Maysville-Corbin & 9.29 & 12.3 & 9.36 & 20.45 & SR12+SR15+SR11+SR21 \\
\hline Cameron & 7.26 & 9.62 & 5.27 & 10.02 & SR53+SR51A+SR51+SR52+SR36A+SR 20 \\
\hline Big Mountain & 1.62 & 2.15 & 0.51 & 3.60 & SR23 \\
\hline Stirling & 9.4 & 12.45 & 2.04 & 15.42 & SR49+SR48+SR42+SR22A+SR22B \\
\hline North Franklin & 4.68 & 6.2 & 2.56 & 6.45 & M32 \\
\hline
\end{tabular}

\footnotetext{
${ }^{1}$ Estimated discharge was computed as the product of MCU area, assumed recharge rate of 18.0 inches per year, and conversion factor of 0.07362.

${ }^{2}$ Measured minimum and maximum discharge was computed as the sum of the minimum or maximum measured discharges, respectively, for sites identified in table 3 .

${ }^{3}$ Although initially considered separate MCUs, the Weston Mine and Raven Run Mine were included with the Packer MCU for consistency with Reed and others (1987). Some AMD sources associated with these mines could not be measured as reported by Cravotta (2005).
} 

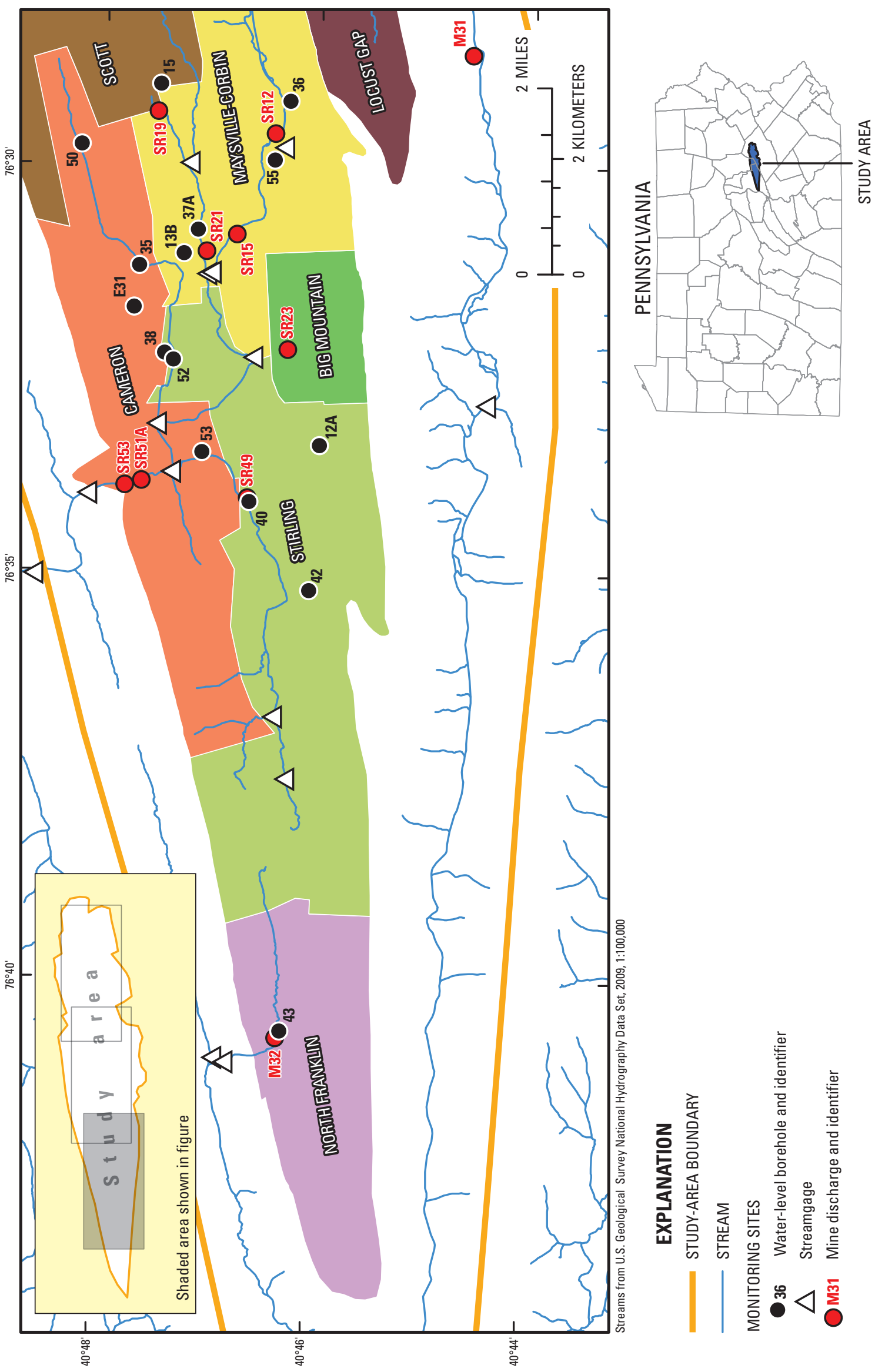

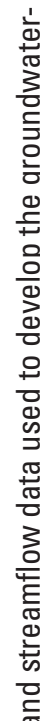

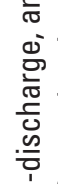

ह.

可

$\frac{\sigma}{1} \mathrm{u}$

离

芆

은

홍

. 흥 음

象

t。

s)

은

엉

它

蒙 흥

음

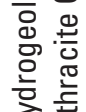

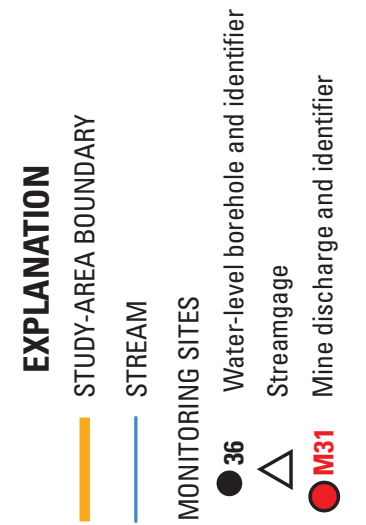

ํㅡㄹ

离离

堊

点

西

웡

రัن

$\infty$ 잉

홀 

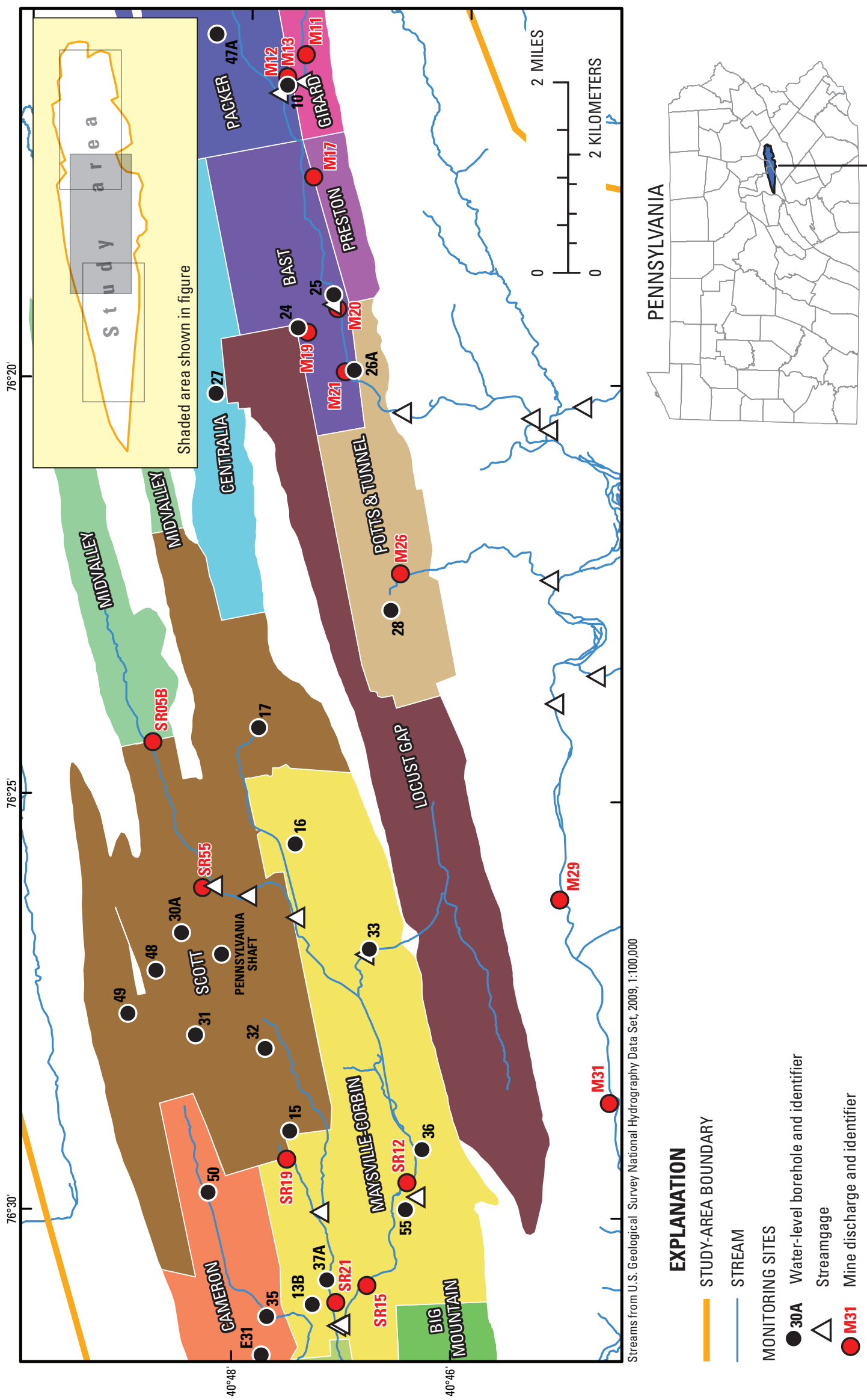

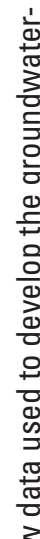

을

离

음

g. $\frac{\pi}{\frac{\pi}{\pi}}$

흔

음

d

.

迥

む)

인

$\pi$

을

은

엉은

즌 듬

के

范

is

으

吾

으 흧

음 른

흥 흥

ง

능 종

잉. 빈

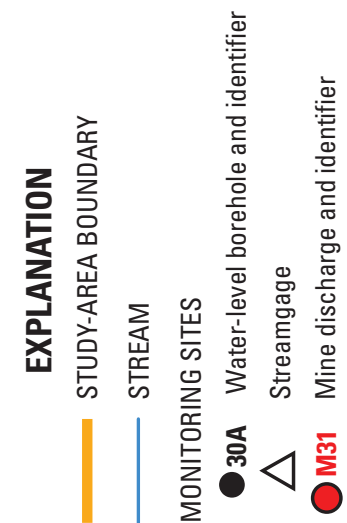

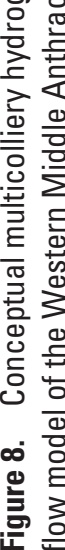



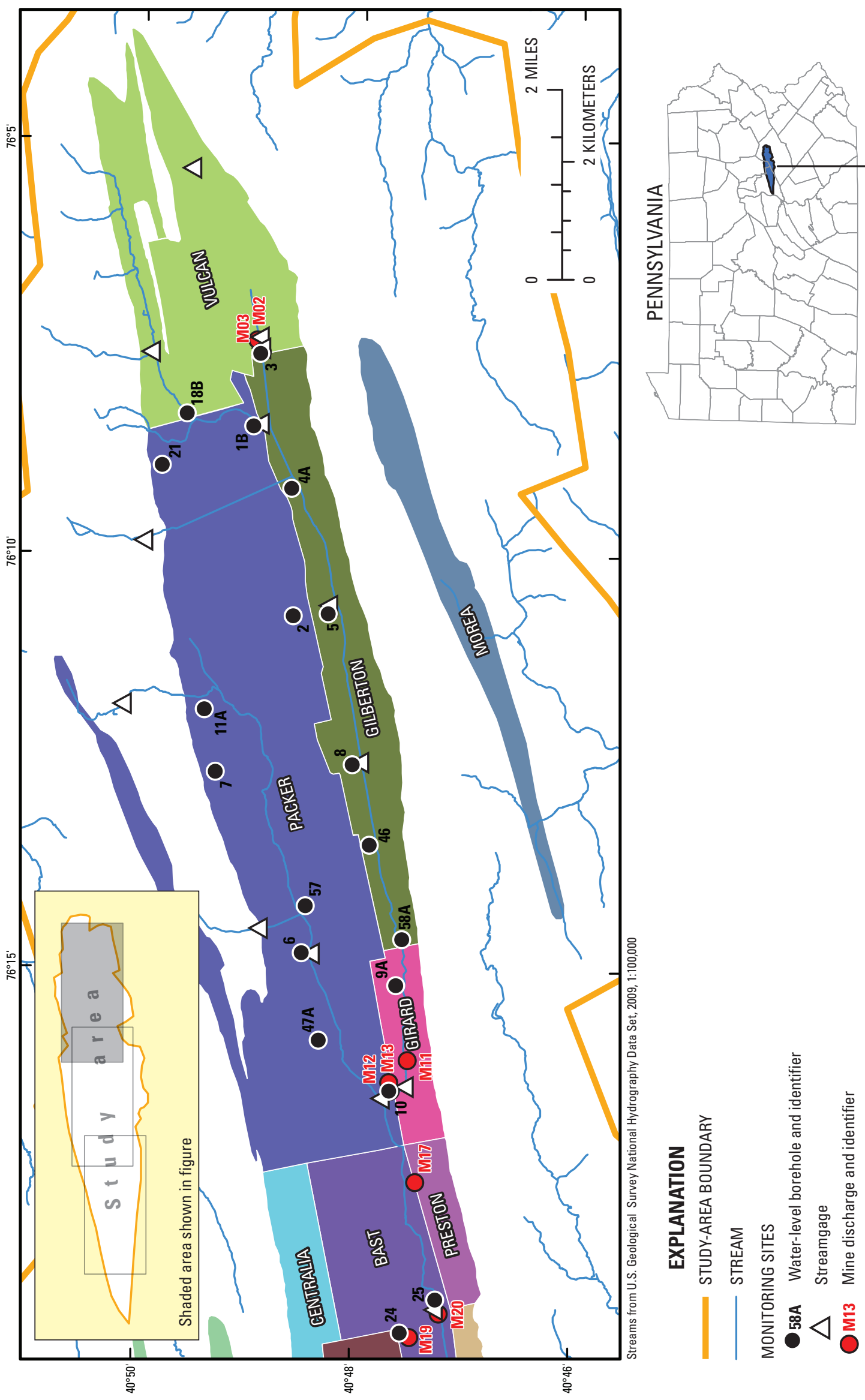

产

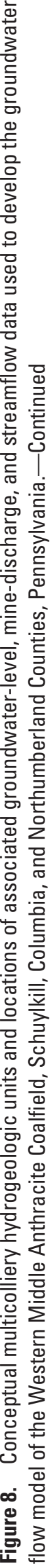

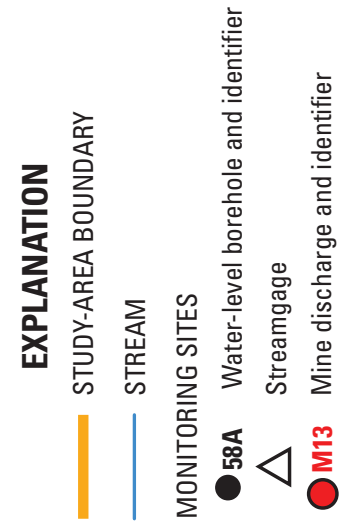
बํ. 突产

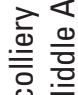
言 $\stackrel{\mathrm{g}}{3}$ 융 
increased metals loads in Mahanoy Creek at Ashland (S16) compared to the sum of metals loading from upstream AMD sources. Groundwater modeling could indicate potential for AMD to discharge within streams or other locations.

\section{Simulated Water Budgets and Effects of Pumping Changes}

The focus of this investigation is on the groundwater accumulated within high-permeability mine workings, flow restrictions through barrier pillars between mines, and the localized discharge of AMD from the flooded mines to streams, pumping wells, or AMD outflows. Given this focus, a groundwater-flow model was developed to simulate groundwater flow through the mines and to compute water budgets in the Western Middle Anthracite Coalfield. The numerical model was based on a simplified conceptual model of the hydrogeologic system, which can be refined iteratively through evaluation of modeling results and additional data collection.

\section{Conceptual Model}

A simplified conceptual model of steady-state recharge, movement, and discharge of groundwater was used to guide development of the corresponding numerical groundwaterflow model of the study area. The groundwater system is conceptualized as a three-dimensional aquifer recharged by uniform infiltration of precipitation and seepage of streamflow in losing stream reaches. The complex geologic structure of the study area is conceptualized as a layered system with different hydraulic properties for the layers. For purposes of this preliminary study, the fractured-rock formations are conceptualized as having a sufficient density of secondary openings (interconnected voids) to approximate a porous medium at the scale of the investigation. These assumptions ignore many of the complexities of the actual groundwater system. Thus, this model should not be used for detailed simulation of flow in individual mines or estimates of hydraulic properties of individual mine barriers, for example. However, this preliminary model tests the conceptual model and illustrates the use of such a model to estimate large-scale water budgets and storage volumes. The conceptual model includes high-permeability flooded mine voids separated by low-permeability barriers, with recharge to the mines from vertical infiltration through overlying strata.

Three model layers are used to represent the groundwater flow system from the land surface down to the deepest mined coal seams. The top model layer 1 represents weathered fractured rock and the overlying soil (regolith) and mine spoil. Model layer 2 represents potentially less-weathered fractured, unmined rock above the mined strata. The properties of these two layers are further assumed to be uniform throughout the study area, except for a potential difference between properties in mined and unmined areas.

The mined strata are included within layer 3, with uniform hydraulic properties within a mine and abrupt changes in hydraulic properties between mined and unmined areas. The permeability is assumed to be negligible beneath the deepest mined coal seams.

Many complex features that may exist in the study area are not included in this simplified conceptual model. For example, transient perched zones have been observed in similar hydrogeologic settings (Callaghan and others, 1998) where shallow fracture zones may be temporarily saturated following recharge events. These features may delay and re-direct recharge to the deep saturated zone, especially where uncased open boreholes exist. For the steady-state model used here, recharge is simply conceptualized as a constant vertical flux to the saturated zone.

Mine-pool discharges are conceptualized as conduits that originate in the flooded mines (model layer 3 ) and discharge to the streams (layer 1) at the land surface. In cases where tunnels or other features route water from the mine location to a surface discharge at a distal location, the interaction between water in the conduit and in the aquifer is ignored along that path.

Groundwater discharge is simplified by considering only discharge to streams, wells, and simulated mine discharges. Although some groundwater discharges as evapotranspiration along the riparian zone of streams, this sink was not considered.

\section{Model Development}

A numerical model was used to simulate three-dimensional groundwater flow in the study area. Simulations were conducted under steady-state conditions. Steady-state simulations give results that represent the groundwater/surfacewater relations for conditions of average annual groundwater recharge and discharge. Transient changes caused by seasonal variations in recharge or changes in pumping rates or locations were not simulated, although steady-state conditions with alternative pumping rates were simulated.

\section{Computer Code and Grid}

The finite-difference computer code MODFLOW-2000 (Harbaugh and others, 2000) was used with the parameter estimation program (Hill and others, 2000) and the particle-tracking program MODPATH (Pollock, 1994) to simulate threedimensional groundwater flow and display results. A graphical user interface linked to Argus Numerical Environments was used for pre- and post-processing of data (Winston, 2000).

The study area was divided into a finite-difference grid (figs. 9 and 10) with 3 layers, 70 rows, and 337 columns. The horizontal dimensions of the cells were uniformly $656 \mathrm{ft}$ 

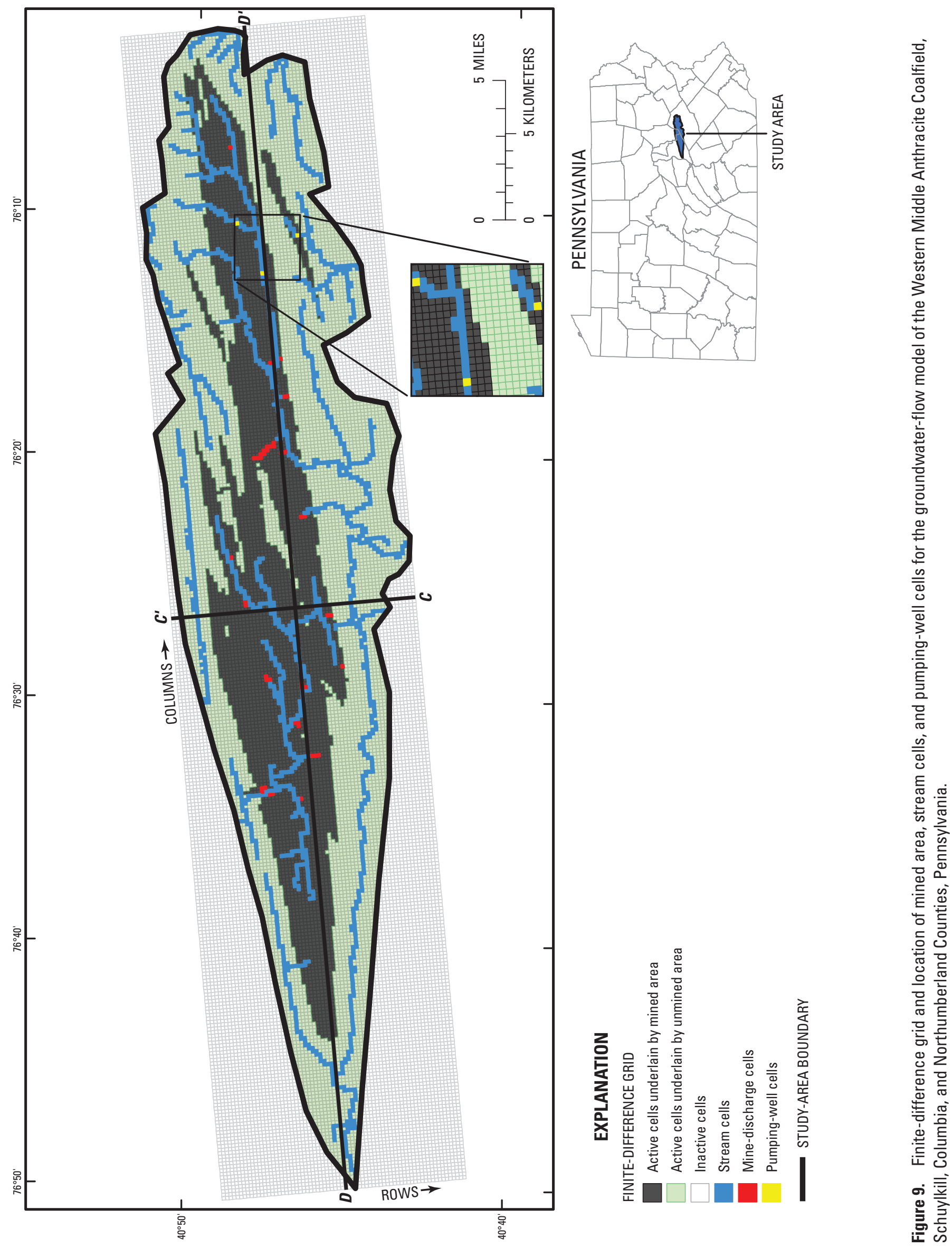

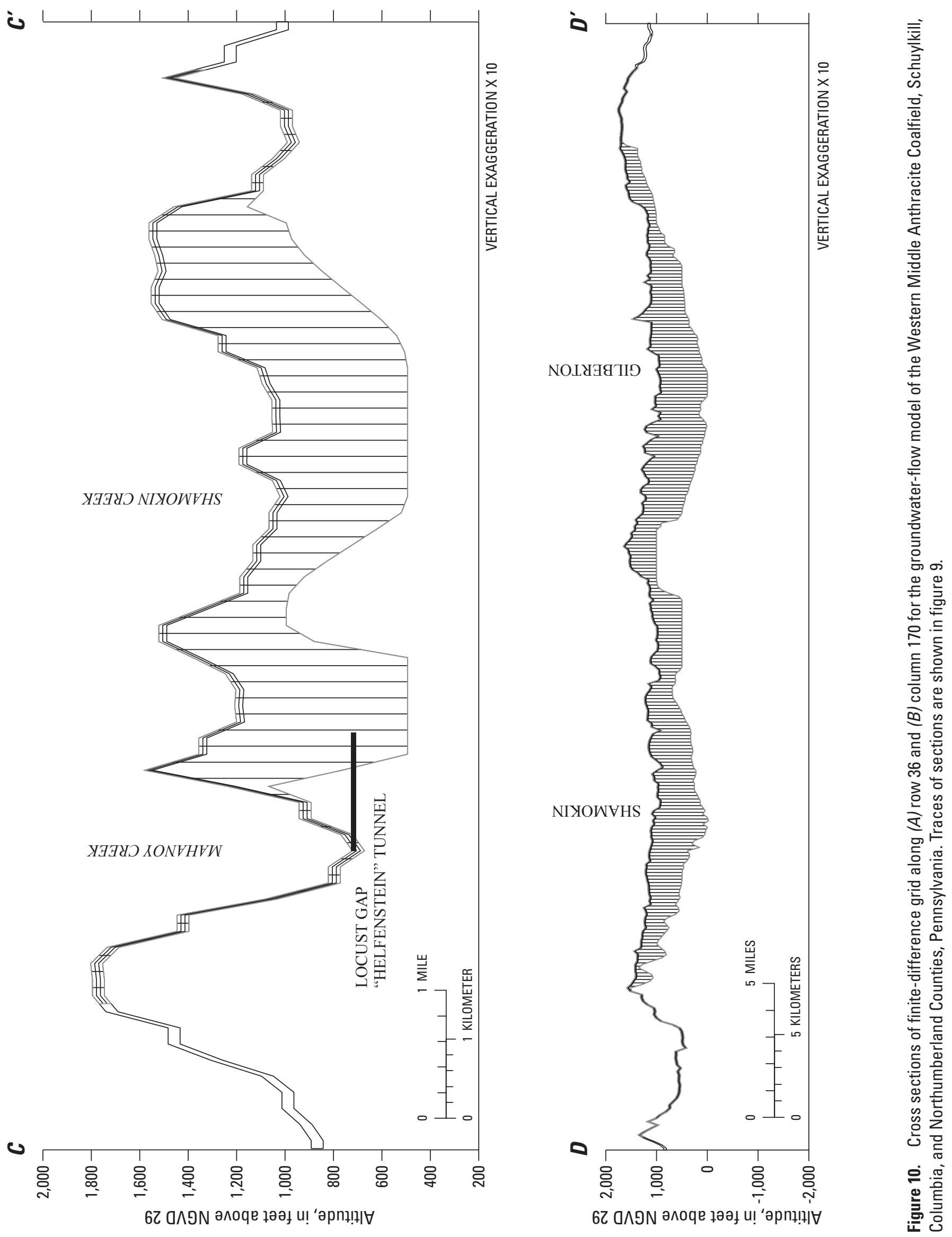
(column width) by $663 \mathrm{ft}$ (row height) in horizontal dimension $^{6}$. The model grid was constructed with rows aligned with the regional structure of the synclinal geologic units in the area (fig. 2).

The altitude of the top of each model cell in layer 1 was set equal to the altitude of land surface on the basis of the USGS 30-m digital elevation model (DEM). The thickness of all cells in model layer 1 was $16.4 \mathrm{ft}$. Layer 1 represents shallow weathered rock and mine spoil in the study area. Model layer 2 is also $16.4 \mathrm{ft}$ thick and represents underlying, unmined bedrock that overlies layer 3. Although data on the extent of weathering and fracturing of unmined bedrock were not available for this preliminary study, the associated hydrological characteristics of the unmined strata are likely to be highly variable (for example, Wyrick and Borchers, 1981; Callaghan and others, 1998). Preliminary simulations indicated that without water-level measurements in shallow parts of the formation, the properties of layers 1 and 2 could not be independently identified; therefore, the properties of layer 2 were assumed for this preliminary model to be the same as layer 1 . With additional information, this same grid could be used with a more-refined conceptual model of the shallow strata. Model layer 3 represents the coal-bearing strata, much of which has been mined using underground room-and-pillar mining techniques.

The thickness of layer 3, representing coal-bearing strata within underground mines, is computed from the depth of mining. The top of layer 3 is at the same altitude as the bottom of layer 2. The bottom of layer 3 (fig. 11) was specified as either $16.4 \mathrm{ft}$ below the top, or the bottom altitude of the deepest mined strata, whichever was lower. The smoothed contour map of the structural contours for the Buck Mountain coal seam represents the modeled altitude of deepest mining in the study area (fig. 4) except where mine map information indicates that the deepest mined strata was above the Buck Mountain seam.

\section{Boundary Conditions}

A no-flow boundary was implicitly specified at the bottom of the model and along the outer boundary of the active model cells. The outer boundary of active model cells was manually digitized at topographic ridges and stream locations outside the Western Middle Anthracite Coalfield. In many locations, especially in the western part of the model area, the boundary was specified along ridgelines running outside valleys adjacent to the coal-area syncline. In the eastern part of the model area, the active area was extended to include small streams draining away from the mined area. Thus, groundwater flow can discharge beneath the local basin boundary to nearby streams, or to local streams within the mined area, depending on model hydraulic conductivity and relative

\footnotetext{
${ }^{6}$ The model was constructed in length units of meters, which are reported in feet for this report, resulting in values that may seem unusual or may convey more precision than warranted.
}

stream altitudes. However, it is implicitly assumed that no groundwater flows across the outside no-flow boundary of the model.

\section{Recharge from Precipitation}

Recharge to the saturated zone from local precipitation was simulated as a uniform flux across the top of each cell. Recharge may actually be greater in mined areas because of the focusing effect of surface pits and waste-pile dams, but for this preliminary modeling, the recharge value was not varied spatially.

\section{Streams}

Streams were simulated by use of the STR package in MODFLOW-2000 (Prudic, 1989), which allows streams to gain or lose water and accounts for the flow in each stream cell (fig. 9) so that losses cannot exceed the simulated streamflow. The stream stage was set equal to the altitude of land surface from the USGS 30-m DEM. The top of the streambed was assumed to be equal to the stream stage, and the bottom of the streambed was $3.28 \mathrm{ft}$ below the stream stage. Stream width was simulated as $3.28 \mathrm{ft}$ for all stream cells. These stream dimensions are not representative of the real stream channels but are used for convenience in these preliminary simulations. As assumed in the simplest computational method available in the STR package (Prudic, 1989), the stream stage does not depend on the simulated streamflow. The hydraulic conductivity of the streambed was adjusted (see discussion on Model Adjustments).

\section{Coal Mines}

Groundwater discharge from the mines was simulated with STR cells in model layer 3 (fig. 9). The altitudes of the STR heads are set to the altitude for the discharge (table 3). These STR cells then route water to the stream network in model layer 1 at the location of the discharge. In some cases, the location of the STR cell in the model is somewhat removed from the surface location of the discharge, especially when the discharge is from a tunnel that extends from the mine to a stream. The model simulates the flow from the mine into the STR boundary, and then that flow is modeled as a tributary flow to a surface stream in model layer 1 . However, in these cases, flow in the tunnel, or in vertical conduits routing water to the surface, and interaction with local groundwater outside the conduit, is not explicitly simulated. MODFLOW numerical algorithms do not require that STR cells and tributaries be in adjacent model cells or layers. This simple approach is considered a preliminary approximation of the complex flow paths that may occur between the flooded mine and the location of the surface discharge.

\section{Wells}

Four pumping wells were simulated to withdraw water from the mine pool for industrial use. These wells are simulated as specified fluxes from model cells in layer 3 (fig. 9). 

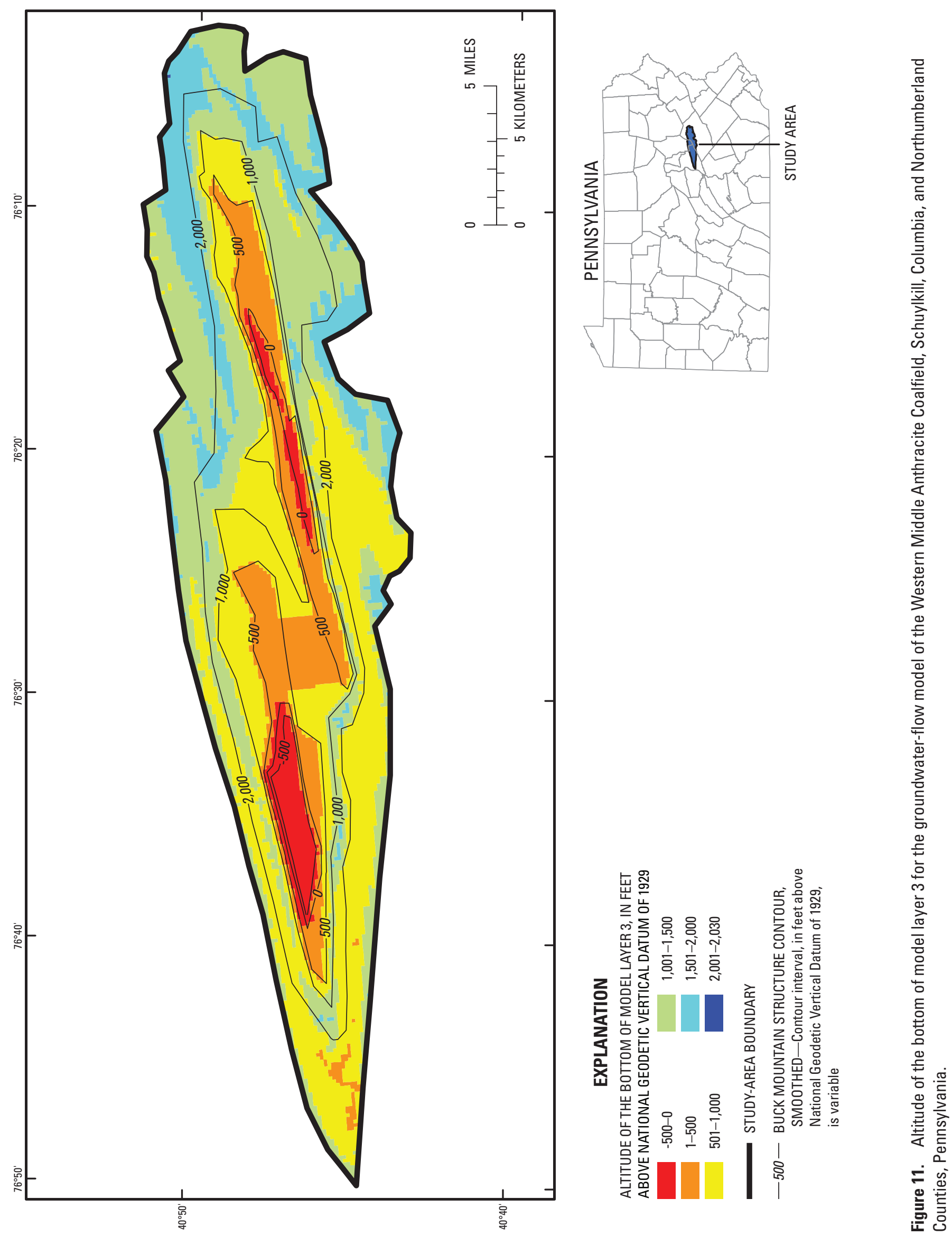
The two pumping wells associated with the Gilberton shaft are located within a single model cell and thus are simulated as a single pumping well in the model.

\section{Aquifer Properties}

Initial estimates of aquifer properties used in the model were based on a preliminary model with homogeneous properties. All parts of the aquifer are assumed to be isotropic in the horizontal and vertical. All parameter values were subsequently changed during the model-adjustment procedures described in the Model Adjustments section.

The MCU concept is reflected in the structure of the parameters for hydraulic properties of the model. The model structure includes a separate zone of hydraulic conductivity for the aquifer formed by flooded coal mines and separate zones for shallow parts of the formation in mined and unmined areas.

Barriers and unmined rock between MCUs may have very low permeability. Barriers are modeled using the Horizontal-Flow Barrier (HFB) package for MODFLOW-2000 (Hsieh and Freckleton, 1993). Barrier locations (fig. 12) were determined from mapped barriers, observed water-level differences between MCUs, and preliminary model-simulation results.

\section{Model Adjustments}

Model adjustment is a process in which aquifer properties are changed to improve the match between the simulated water levels and flows of the model and the measured water levels and flows in the physical system. Aquifer properties and recharge in the model were adjusted by use of the parameterestimation program that is integrated into MODFLOW-2000 (Hill and others, 2000) and by manual adjustments. Values of recharge, hydraulic conductivity, and streambed hydraulic conductivity in the model were adjusted by trying to match measurements of (1) average water levels in 42 observation wells monitored by PaDEP (table 5) and (2) streamflow measured by USGS (Cravotta and Kirby, 2004; Cravotta, 2005) at 33 locations (table 2). Additional historical data from other sources and from new field studies could be incorporated to refine values of aquifer properties, as well as refine barrier locations, discharge locations and altitudes, and other aspects of the model.

\section{Weighting of Measurements}

In the parameter-estimation program, residuals (computed as the difference between observed and simulated values) in streamflow were multiplied by a weighting factor, primarily to convert discharge rates to the same units as waterlevel measurements. The value of the weighting factor was chosen so that the sum of weighted residuals for the streamflow measurements would be about the same magnitude as for the sum of weighted residuals for water-level data from wells. Streamflow residuals, in cubic meters per day, were each multiplied by 0.001 , yielding about half of total model error due to flow errors.

For preliminary model simulations, none of the waterlevel measurements were weighted (weighting factor $=1$ ). This is a limitation of the preliminary work that could affect estimates of hydraulic parameters and limits the usefulness of the uncertainty estimates from the model-calibration procedures.

\section{Adjusted Model Parameters}

Eight parameters were used to represent hydrologic properties in the model (table 7). Five parameters were used to estimate the aquifer hydraulic conductivity, and two parameters were used for streambed vertical hydraulic conductivity. The uniform recharge rate was defined by parameter RECH. Each parameter was either assigned a value or it was optimized by the parameter-estimation process in MODFLOW-2000. Model adjustments focused on parameters that, when changed, caused the greatest proportional change in simulated water levels and flow, which are indicated by their composite scaled sensitivities (fig. 13). The composite scaled sensitivity is the rate of change in the parameter-estimation optimization objective function for incremental changes in the parameter value, normalized by the optimum parameter value. Thus, the overall model error changes the most for (proportional) changes in parameters with the highest composite scaled sensitivities (Hill and others, 2000). Changes to the values of parameters that have low composite scaled sensitivity will cause small changes in the model error. Values for KM, STR, and RECH were optimized by MODFLOW-2000, and the others were assigned values on the basis of the initial automatic parameter-estimation trials. These manually adjusted values were specified for parameters for which the automatic procedure yielded unrealistically low or high values and for insensitive parameters that did not substantially affect model error. Parameter K1 had a relatively high composite scaled sensitivity, but it was also correlated with RECH, KM, and STR, and for this reason its value was manually assigned after several initial optimizations.

The adjusted values of hydraulic conductivity used in the model are shown in table 7. Parameters K1 and K3 were manually limited to reasonable values. Model error was relatively insensitive to $\mathrm{K} 3$, probably because all groundwaterlevel measurements were in mined areas and this parameter is applicable in deep unmined areas. Although the sensitivity to $\mathrm{K} 1$, the hydraulic conductivity of shallow parts of the aquifer above the mine layer, is relatively large, automatic calibration yielded an unrealistically low value of the hydraulic conductivity of shallow aquifers, resulting in groundwater levels well above land surface. Use of measurements of shallow aquifer groundwater levels would likely yield a much better estimate of this parameter. Model error was minimized with low values of these parameters, but K1 was set high enough to prevent excessively high water-levels in unmined areas. If 

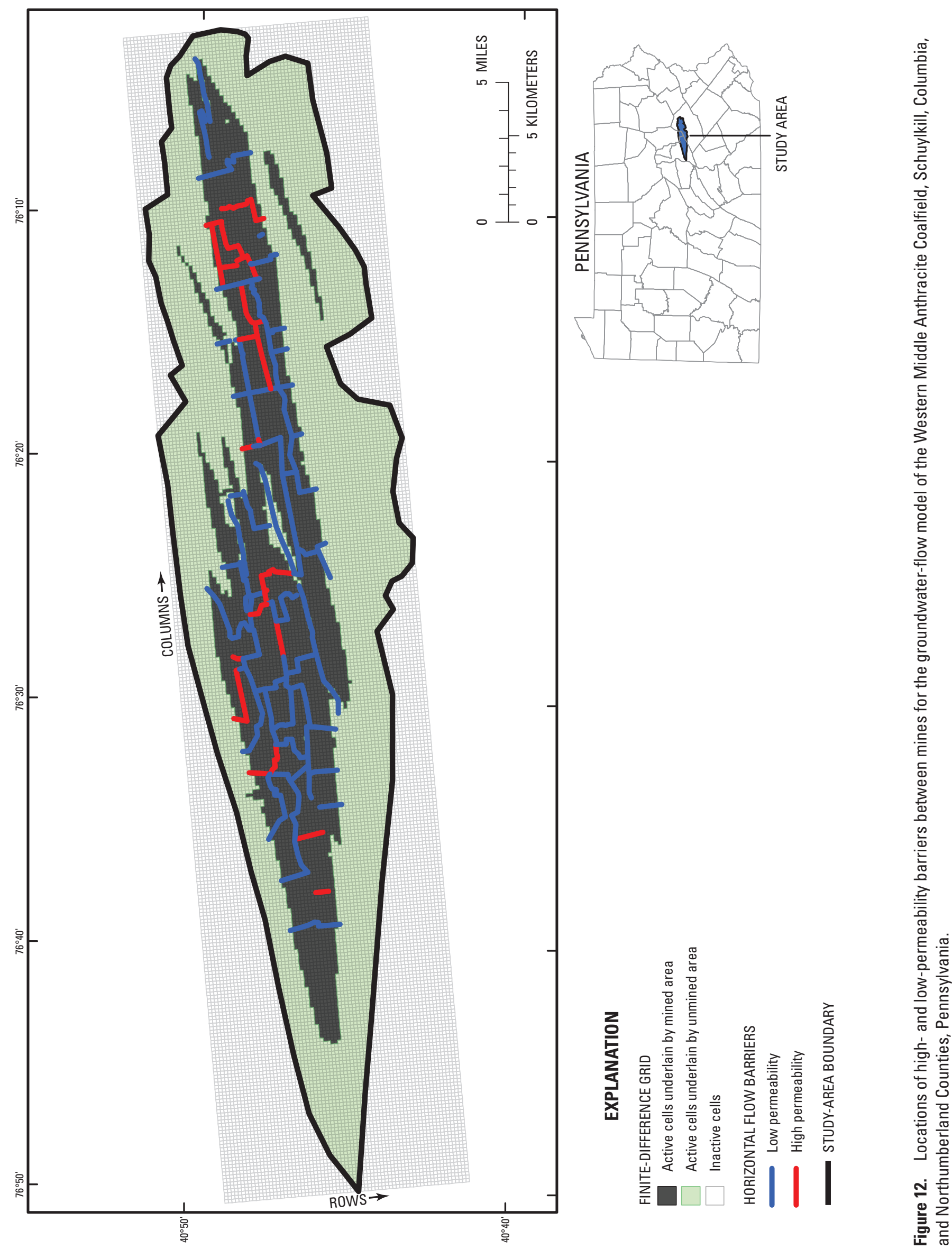
Table 7. Parameters used in the groundwater-flow model of Western Middle Anthracite Coalfield, Schuylkill, Columbia, and Northumberland Counties, Pennsylvania.

[ft/d, feet per day; in/yr, inches per year; AUTO, automatic calibration; MAN, manual limit based on preliminary automatic calibration]

\begin{tabular}{|c|c|c|c|c|}
\hline $\begin{array}{l}\text { Parameter } \\
\text { name }\end{array}$ & Description & Model layer & $\begin{array}{c}\text { Adjusted value } \\
\text { (ft/d, except as indicated) }\end{array}$ & $\begin{array}{l}\text { Estimation } \\
\text { method }\end{array}$ \\
\hline K1 & $\begin{array}{l}\text { Hydraulic conductivity of overburden and shallow weathered } \\
\text { rocks }\end{array}$ & 1 and 2 & 3.28 & MAN \\
\hline K3 & Hydraulic conductivity of deep unweathered, unmined rocks & Unmined parts of 3 & 0.0033 & MAN \\
\hline STR & Streambed hydraulic conductivity of natural streams & 1 & 1.95 & AUTO \\
\hline STRC & Streambed hydraulic conductivity of coal-mine discharges & 3 & 656 & MAN \\
\hline KB_HIGH & $\begin{array}{l}\text { Hydraulic conductivity of high-permeability barriers that do } \\
\text { not restrict flow between MCUs }\end{array}$ & 3 & 3.28 & MAN \\
\hline RECH & Uniform recharge to groundwater & 1 & $19.1 \mathrm{in} / \mathrm{yr}$ & AUTO \\
\hline
\end{tabular}

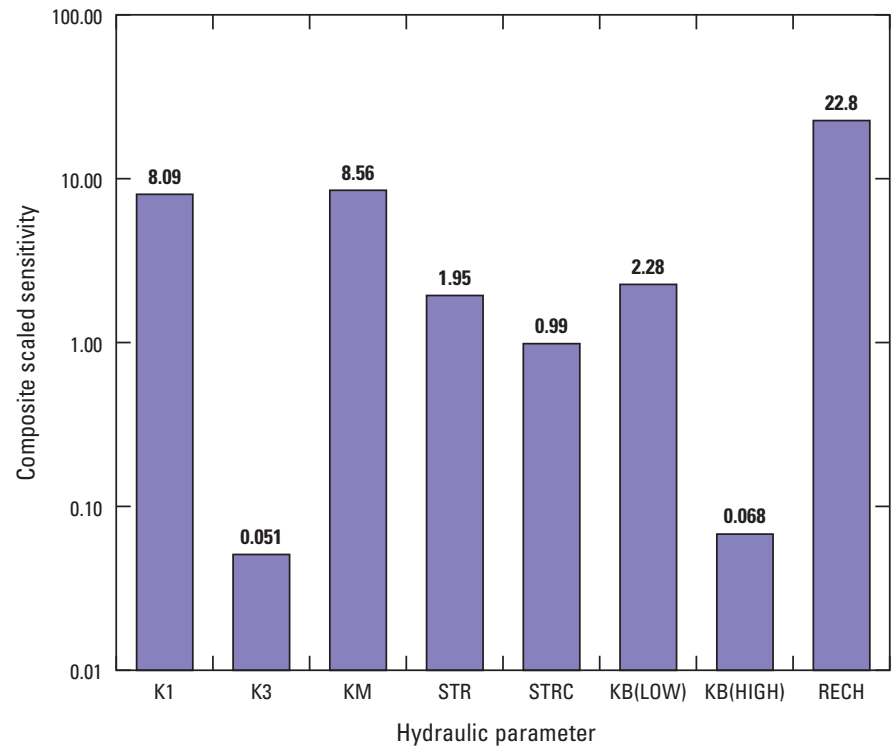

Figure 13. Composite scaled sensitivity of hydraulic parameters used in the groundwater-flow model of the Western Middle Anthracite Coalfield, Schuylkill, Columbia, and Northumberland Counties, Pennsylvania. (See table 2 for definition of parameters.)
$\mathrm{K} 1$ is reduced much further, simulated water levels outside the model area would be well above land surface in many areas.

Automatic calibration procedures were used to identify the optimum value of parameter KM, the hydraulic conductivity of the flooded coal mines, $\mathrm{KM}=77.9 \mathrm{ft} / \mathrm{d}$. This high value supports the conceptual model of high permeability, or little resistance to flow, and hence little water-level variability, within flooded mines. For comparison, Saad and Cravotta (1991) estimated the hydraulic conductivity of coal-mine spoil as 10 to $100 \mathrm{ft} / \mathrm{d}$ using a cross-sectional flow model. In contrast, Harlow and LeCain (1993) reported a median transmissivity value of about $0.1 \mathrm{ft}^{2} / \mathrm{d}$ for unmined coal seams, which would correspond, for a 3-ft seam, to a hydraulic conductivity value of about $0.03 \mathrm{ft} / \mathrm{d}$. Thus, the hydraulic conductivity estimated in the present study for the flooded coal-mine layer in the model is orders of magnitude larger than the hydraulic conductivity of unmined coal.

Model results indicate that some barriers are restrictive for flow between MCUs, while other mapped barriers do not substantially restrict flow. Model error is lowest for a very low value of KB LOW of $3.28 \times 10^{-4} \mathrm{ft} / \mathrm{d}$ and a very high value of $\mathrm{KB}$ HIGH of $3.28 \mathrm{ft} / \mathrm{d}$. The value used here for intact barriers is much lower than estimates by McCoy and others (2006) of 0.12 to $0.59 \mathrm{ft} / \mathrm{d}$ for intact bituminous coal barriers. Harlow and LeCain (1993) report unmined coal seam hydraulic conductivities of as low as $10^{-4} \mathrm{ft} / \mathrm{d}$, as tabulated by McCoy and 
others (2006, p. 280). An example of the effect of changing barrier hydraulic conductivity is discussed below. A systematic test was not done to see how results would change for different designations, or model structures, of which barriers are intact and which are not.

The streambed vertical hydraulic conductivity for the natural streams in model layer 1 , STR, is estimated to be $1.95 \mathrm{ft} / \mathrm{d}$. This value is large enough that the differences between the aquifer water levels in the stream cells and the stream altitudes are less than $5 \mathrm{ft}$. Most available information about this parameter is from other regional model studies. Lewis-Brown and others (2005) noted that "the vertical hydraulic conductivity of a streambed is difficult to measure in the field" and estimated a parameter value of $1 \mathrm{ft} / \mathrm{d}$ for a model of flow in a fractured-rock aquifer in the Passaic Formation of the Newark Basin. Carleton and Gordon (2007) used streambed vertical hydraulic conductivities of 0.13 to $26 \mathrm{ft} / \mathrm{d}$ for a model of flow in a carbonate valley. Risser (2006) used streambed vertical hydraulic conductivities of up to $500 \mathrm{ft} / \mathrm{d}$ for streams in an area with carbonate rocks known to exhibit karstic features.

STRC, the streambed vertical hydraulic conductivity for mine discharges in model layer 3 , was set at a limiting value, $656 \mathrm{ft} / \mathrm{d}$. Model error was minimized with higher values but was only slightly smaller because model error is insensitive to this parameter. However, calibration does indicate that this value should be large. This value is similar to the highest value, $500 \mathrm{ft} / \mathrm{d}$, used by Risser (2006) for surface streams in a carbonate valley underlain by karst.

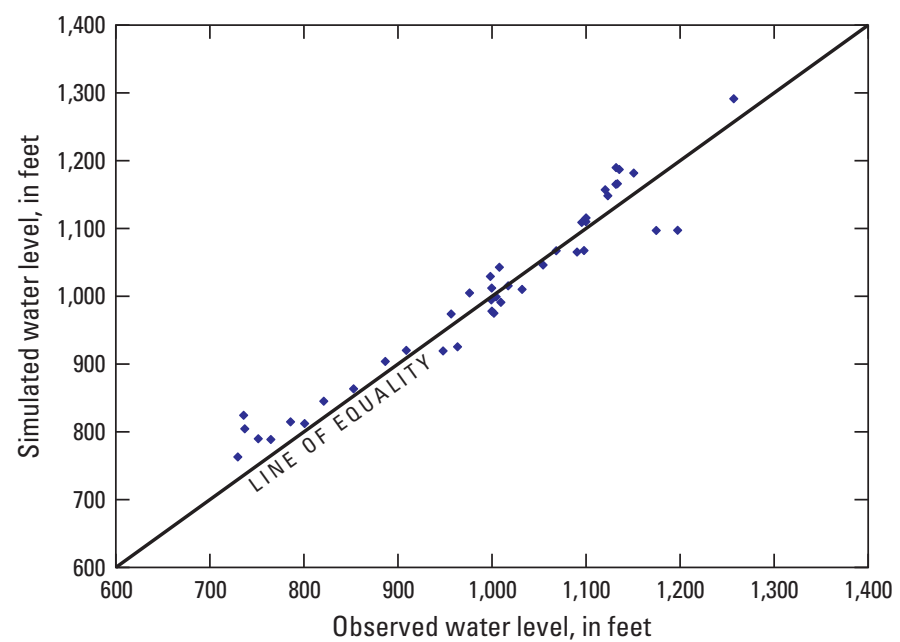

Figure 14. Relation between observed and simulated groundwater levels simulated by use of the groundwater-flow model of the Western Middle Anthracite Coalfield, Schuylkill, Columbia, and Northumberland Counties, Pennsylvania.
Automatic calibration procedures were also used to estimate the recharge rate (RECH) of $19.1 \mathrm{in} / \mathrm{yr}$. This estimate compares well with the long-term estimates of recharge of 18.8 to $21.0 \mathrm{in} / \mathrm{yr}$ computed by Risser and others (2005) and $17.6 \mathrm{in} / \mathrm{yr}$ computed by Becher (1991) on the basis of streamflow hydrograph analysis for Shamokin Creek near Shamokin. These recharge estimates also compare well with the baseflow yields estimated for the middle and lower reaches of Shamokin Creek (18.0 to $22.6 \mathrm{in} / \mathrm{yr}$ ) and the lower reaches of Mahanoy Creek (17.0 to 19.7 in/yr) (table 2).

Simulated and observed water levels are compared in figure 14. Steady-state groundwater levels simulated by the model are compared to the average of the mine-pool waterlevel data (table 5). The model simulates the regional differences in groundwater altitude reasonably well with a rootmean-square error of $11.2 \mathrm{ft}$; however, the differences between simulated and observed water levels are as large at $100 \mathrm{ft}$ (fig. 14), probably because of local heterogeneity of the formations and mines. Note that most boreholes exhibited temporal variations in water level of 20 to $60 \mathrm{ft}$ (table 4). This suggests that the preliminary model should be used with caution for making predictions at the local scale.

Streamflow simulated by the model was compared to measured flow from the synoptic surveys of 1999-2001 (fig. 15). The simulated rate that water is gained or lost in streams is sensitive, in part, to the hydraulic conductivity of the streambed. A single value of streambed hydraulic conductivity was used for the entire model area for streams in model layer 1. Streams in model layer 3 represent mine discharges

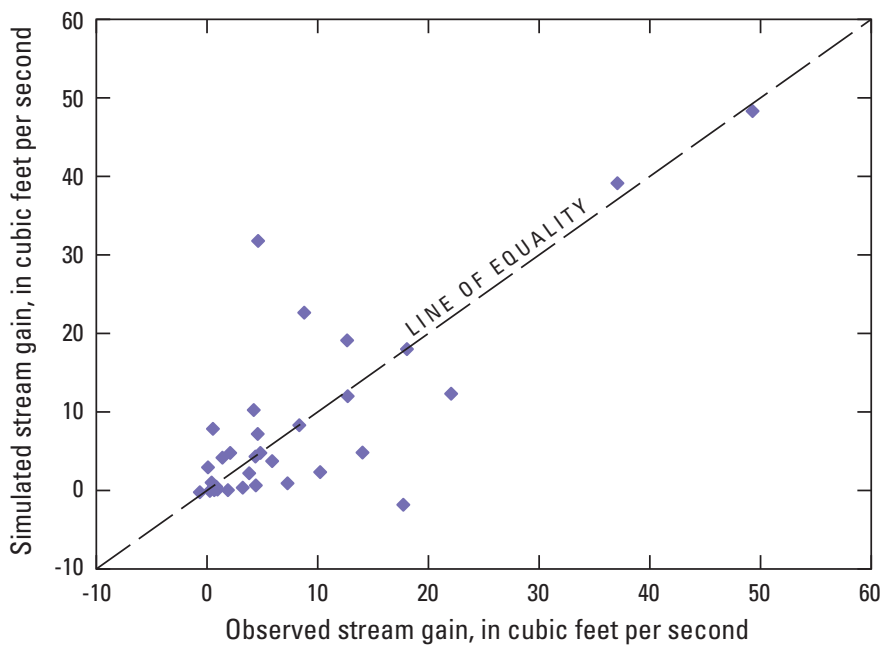

Figure 15. Relation between observed and simulated base-flow gain $(>0)$ or loss $(<0)$ simulated by use of the groundwater-flow model of the Western Middle Anthracite Coalfield, Schuylkill, Columbia, and Northumberland Counties, Pennsylvania. 
and are modeled with a separate value of streambed hydraulic conductivity, which is also uniform for the entire model area.

The simulated stream base-flow gains do not match the observed values as well as the groundwater levels. The two large observations are reproduced fairly well, indicating that the model reasonably matches the overall recharge and base flow for the model area. However, local gains and losses on smaller streams are not well matched, probably because of local heterogeneity that is not well characterized in the preliminary model.

\section{Preliminary Results of Model Simulations}

Preliminary results from modeling simulations are described in this section. Simulations were conducted for three cases: (1) current conditions, (2) increased pumping in the Gilberton area, and (3) an example of additional model adjustments to simulate a specific mine-discharge rate that was not reproduced by the calibrated model.

\section{Current Conditions}

Groundwater flow in the study area was simulated under steady-state conditions corresponding to average recharge and pumping, and conditions reflected by the streamflow and water-level measurements used for model calibration. The simulated water-table surface is shown in figure 16. Water levels are relatively flat within simulated MCUs and relatively steep outside the mined area. Large hydraulic gradients also occur across many simulated barriers between MCUs. These results are generally consistent with observed waterlevel data where more than one well is available within a single MCU. However, no water-level information outside the mined area, or in shallow parts of the aquifer, was used for this preliminary study.
The results of the groundwater-flow model include contribution areas for discharges. The source of water for the system is recharge from the water table and streamflow loss, and different areas contribute recharge to different discharges. Forward particle tracking using MODPATH (Pollock, 1994) determined the ultimate discharge locations of parcels of water originating at the top of each cell in the top layer of the model. In general, areas near streams contribute recharge to streams, and areas upgradient from pumping wells contribute water to the wells. Mine discharges capture substantial amounts of the groundwater in the mined areas (fig. 17).

A water budget for the aquifer system was computed from the model results (table 8 ). On average, most recharge in the study area discharges as base flow to streams, but 41.1 percent discharges from mine outflows, and about 1.5 percent discharges from pumping wells. Model limitations, including few hydraulic parameters, result in simulated discharges that do not match measured discharges at many locations. For example, the largest measured discharge in the Shamokin Creek Basin, at the Scott Ridge Mine Tunnel (table 3, SR19, 9.4 to $19 \mathrm{ft}^{3} / \mathrm{s}$ ), is simulated as zero discharge in the calibrated model. The next section presents an example of modifying model parameters to provide better resolution of particular model results.

The stream reaches that were simulated as providing recharge to the aquifer (base-flow loss) and receiving discharge from the aquifer (base-flow gain) for current conditions are shown in figure 18. The data are shown as shading of finite difference cells according to the rate of volumetric recharge to the groundwater system from the stream; base-flow gain is shown as negative recharge and base-flow loss is shown as positive recharge. Reaches that were neither gaining nor losing reaches are dry; these are indicated by no shading of the finite difference cell where the stream is located.

Outside the mined area, nearly all streams are gaining in the steady-state model. Minor areas of simulated loss may

Table 8. Water budget for current conditions simulated by use of the groundwater-flow model of the Western Middle Anthracite Coalfield, Schuylkill, Columbia, and Northumberland Counties, Pennsylvania.

\begin{tabular}{|c|c|c|}
\hline Source of inflow & $\begin{array}{c}\text { Rate } \\
\text { (cubic feet per second) }\end{array}$ & \\
\hline Recharge & 350.3 & \\
\hline Source of outflow & $\begin{array}{c}\text { Rate } \\
\text { (cubic feet per second) }\end{array}$ & Percent of total outflow \\
\hline Net discharge to streams, excluding mine discharges & 197.5 & 56.4 \\
\hline Stream gains & 205.1 & \\
\hline Stream losses & 7.5 & \\
\hline Mine discharge & 147.3 & 42.1 \\
\hline Pumping wells & 5.4 & 1.5 \\
\hline
\end{tabular}



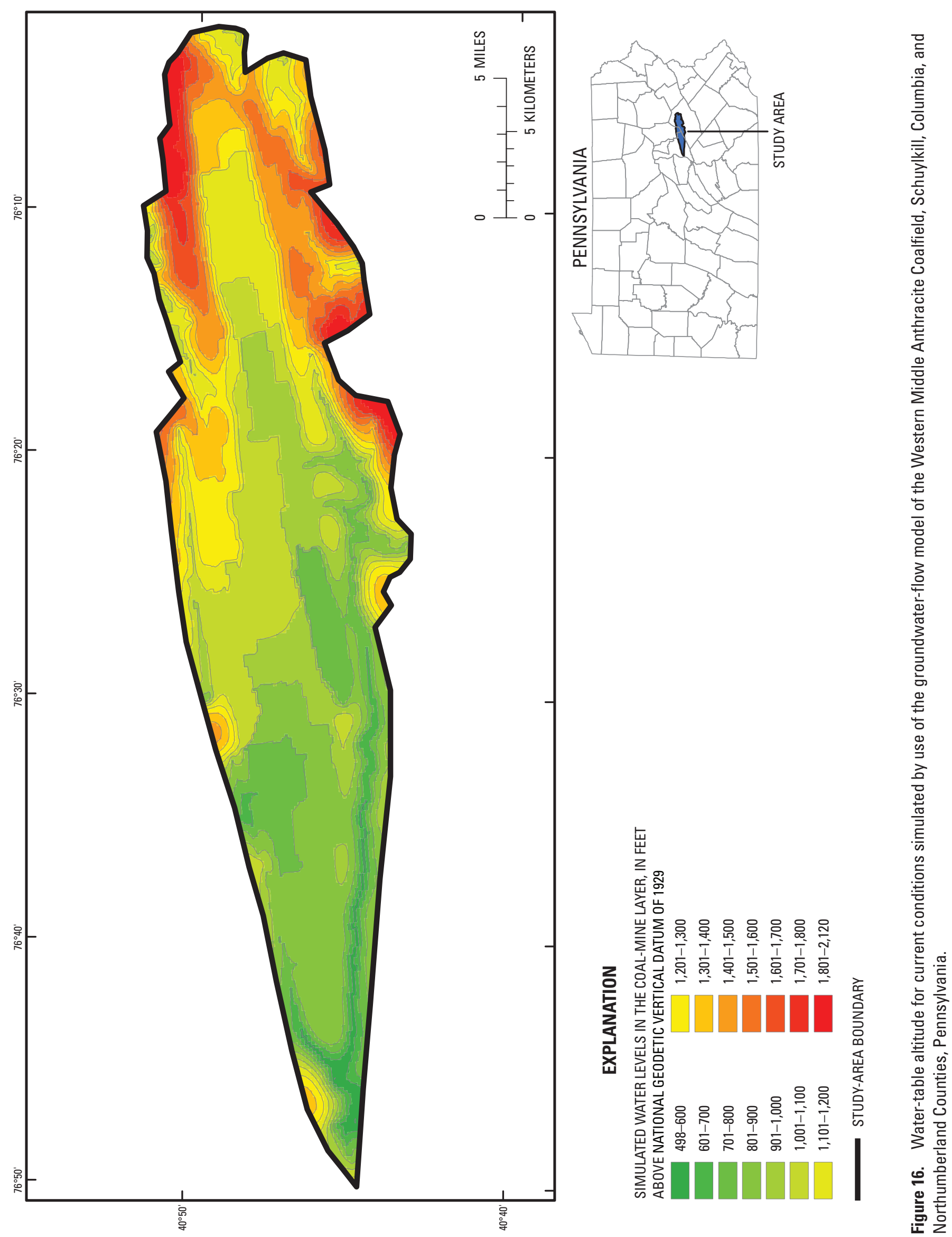

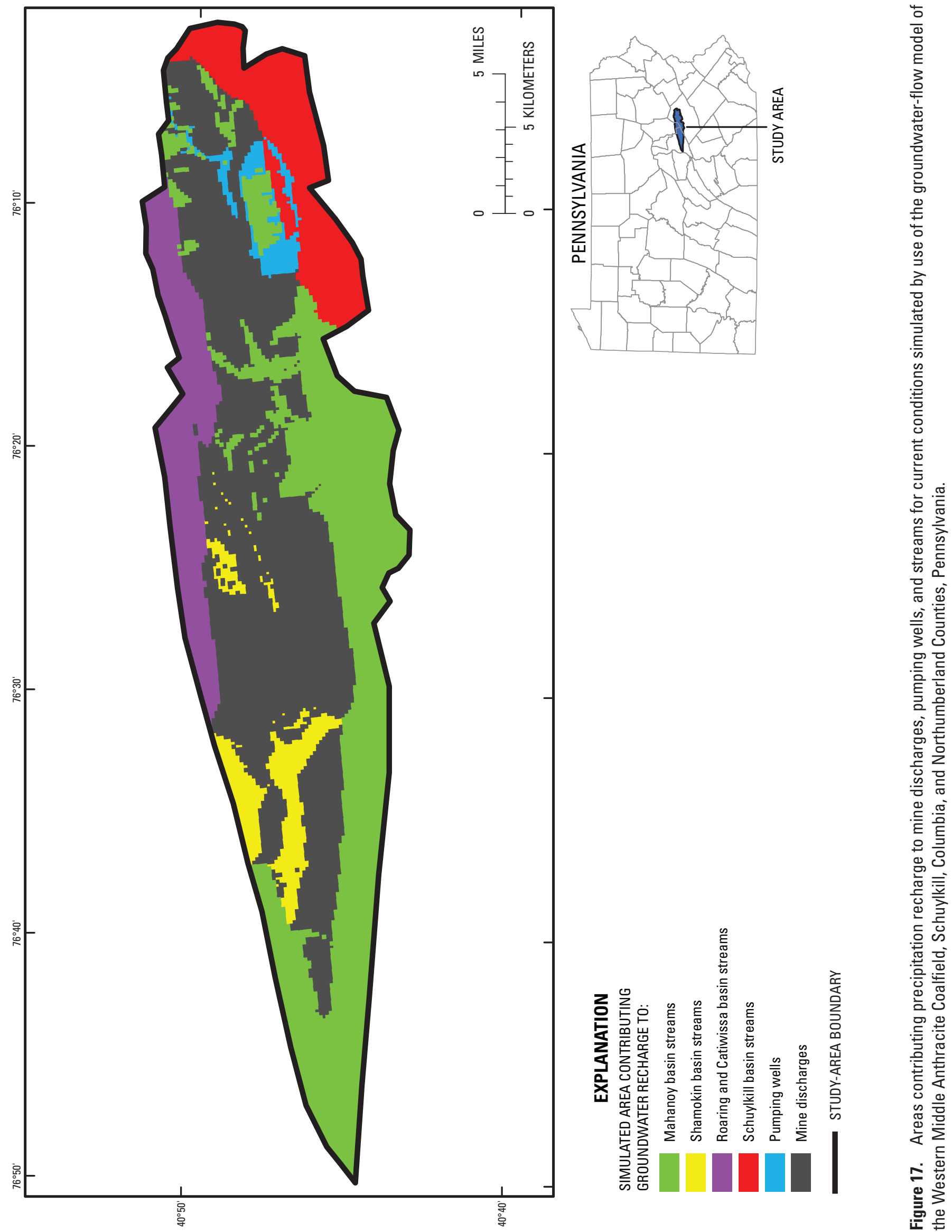

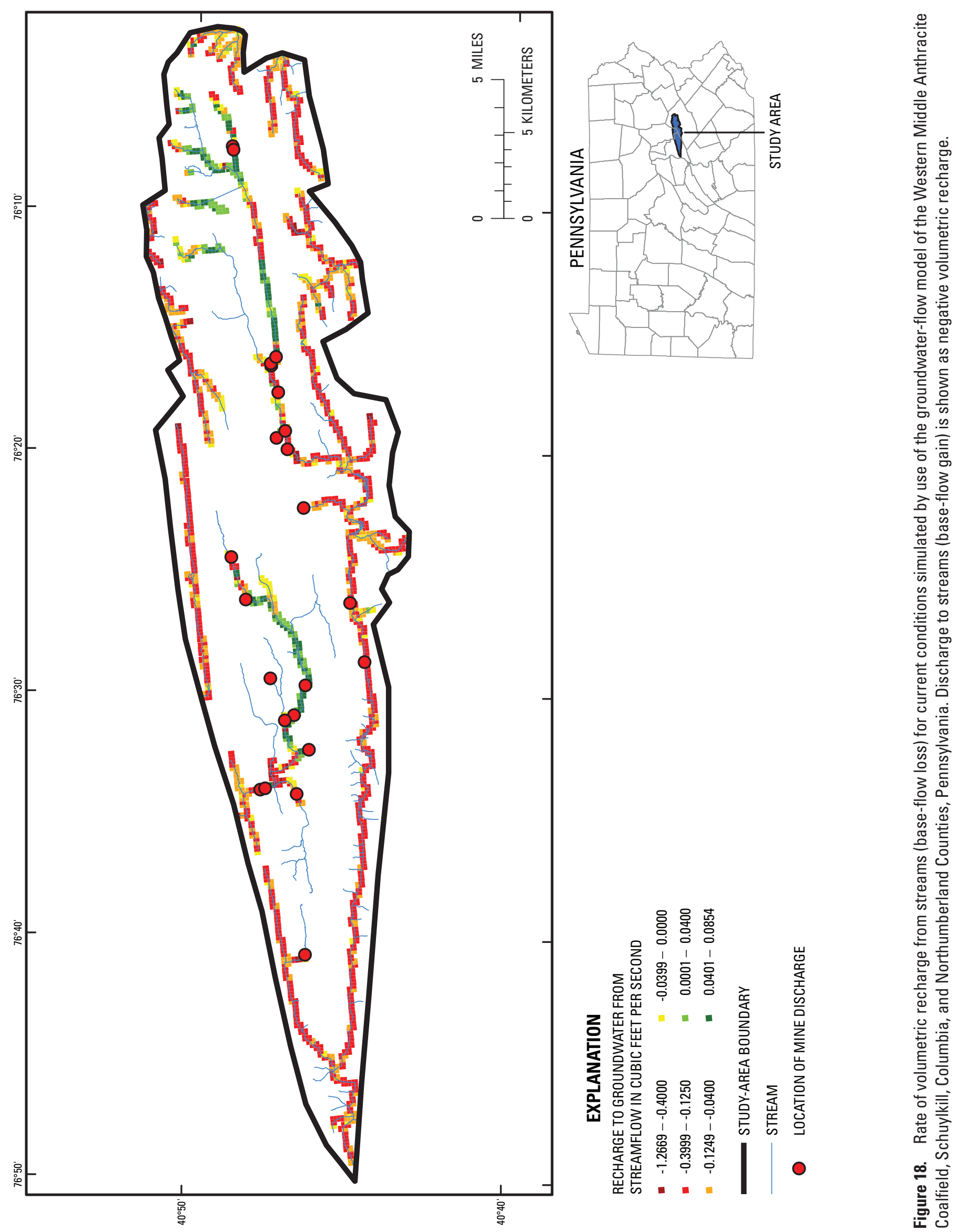
be related to inaccurate stream altitudes in the model, which were estimated from the 30-m DEM. In contrast, many areas of stream loss are simulated within the mined area. Streamflow in headwater streams originating outside the mined area is lost to the aquifer above the mines as the stream flows into the mined area. This captured streamflow mostly flows to mine discharges, which flow back into streams, and some flows to pumping wells. However, the streamflow loss may not necessarily return to the same stream network when it eventually discharges.

\section{Increased Pumping in Gilberton Area}

The groundwater-flow model can be used to simulate the impact of changes in hydrologic conditions, such as changes in pumping from wells. Increased pumping will lower water levels in the vicinity of the pumping well. The magnitude and spatial extent of water-level decrease, or "drawdown," in the aquifer is controlled by the aquifer properties and groundwater boundary conditions. The increased groundwater discharge to the well will be balanced by reductions in other discharges or increases in recharge. In this study, recharge from precipitation is assumed to be unaffected by pumping, but stream baseflow loss (recharge from streams) can increase with increased pumping. Thus, increased pumping will be balanced by decreases in mine discharges and net discharge to streams.

The groundwater flow in the basin was simulated under steady-state conditions with an increase of pumping withdrawals in the Gilberton area of $7 \mathrm{Mgal} / \mathrm{d}$, which has been approved by the Susquehanna River Basin Commission (2005) for a proposed coal gasification and liquefaction facility. All other model parameters and input were the same as the currentconditions case. The simulations indicate that, when compared to current conditions, increased pumping in the Gilberton area has an effect on regional groundwater levels and on locations of source zones for mine discharges and, to a lesser extent, streamflow. The rates of discharge to AMD and net discharge to streams are also reduced.

The simulated drawdown in regional groundwater levels from current conditions caused by the increased pumping of $7 \mathrm{Mgal} / \mathrm{d}$ in the Gilberton area is shown in figure 19. The largest decline is centered near the Gilberton shaft, where the pumping takes place. The shape and extent of the area of influence reflects the high hydraulic conductivity of the MCUs and the restriction to flow across mine barriers. Drawdown gradients are steepest at mine-barrier locations. Although figure 19 shows only the area with a simulated drawdown of $1 \mathrm{ft}$ or more, the influence of the groundwater withdrawal extends to the boundaries of the model area at steady state.

The areas contributing recharge from precipitation to gaining streams, mine discharges, and pumping wells are also shown in figure 19. The total area of recharge from precipitation flowing to the pumping wells is increased. Some of the water that would have discharged as mine outflows or as streamflow is now flowing to the pumping well. Changes in the source areas extend beyond the pumped MCUs. These changes in source and discharge relations reflect the complex three-dimensional patterns of groundwater flow in the highly heterogeneous mine and barrier aquifer system.

The simulated water budget with increased pumping in the Gilberton area is shown in table 9. Compared to the budget for current conditions (table 8), the differences are increased discharge to pumping wells, reductions in discharges to mine discharges and streams, and a small increase in streamflow loss. Most of the increased flow to the pumping well is balanced by a reduction in discharge from mine outflows.

\section{Example of Additional Model Adjustments}

Although the preliminary groundwater-flow model qualitatively reproduces many features of the actual flow system, such as mine outflows and dry, losing, and gaining stream segments, some of the observed hydrological features are not well-reproduced. For example, the model simulated no discharge at the Scott Ridge Mine Tunnel; however, this is the largest observed discharge in the Shamokin Creek Basin. This section presents an example of how model parameters and structure could be further adjusted to better match specific observed features. By changing the model structure and adding new parameters, it is likely that the overall model error could also be further reduced. However, additional adjustments, other than that illustrated here as an example, were beyond the scope of this study.

To better match the observed flow at the Scott Ridge Mine Tunnel, an alternative model with modified mine barriers and mine hydraulic conductivity was constructed. Changes to the model were (1) barrier hydraulic conductivity reduced from KB_HIGH to KB_LOW for barriers between the Natalie and Hickory Ridge collieries; (2) barrier hydraulic conductivity increased from KB_LOW to KB_HIGH for the Scott, Pennsylvania, and Sioux No. 1 collieries; and (3) hydraulic conductivity of model layer 3 , representing mined strata, increased to $3,280 \mathrm{ft} / \mathrm{d}$. The locations of these changes are shown on figure 20 . The preprocessor provided full control of the model parameters and structure and included a graphical user interface for changing other model features, such as pumping rates at wells, and well locations.

This example shows that the model parameters can be further refined to better match specific observed features. After refinement, the simulated discharge at the Scott Ridge Mine Tunnel was $17.6 \mathrm{ft}^{3} / \mathrm{s}$, compared to the observed discharge rate of $17.5 \mathrm{ft}^{3} / \mathrm{s}$. The preliminary model for current conditions described above did not simulate any mine discharge at this model location.

It should be noted, that overall, the model error was increased by the changes for this example to match the discharge from the Scott Ridge Mine Tunnel because water levels and discharges also changed at other model locations. Future refinement of the model could focus on modification of model parameters and structure that improved the match to specific model features while also reducing overall model error. However, these refinements were not pursued for this preliminary model. 

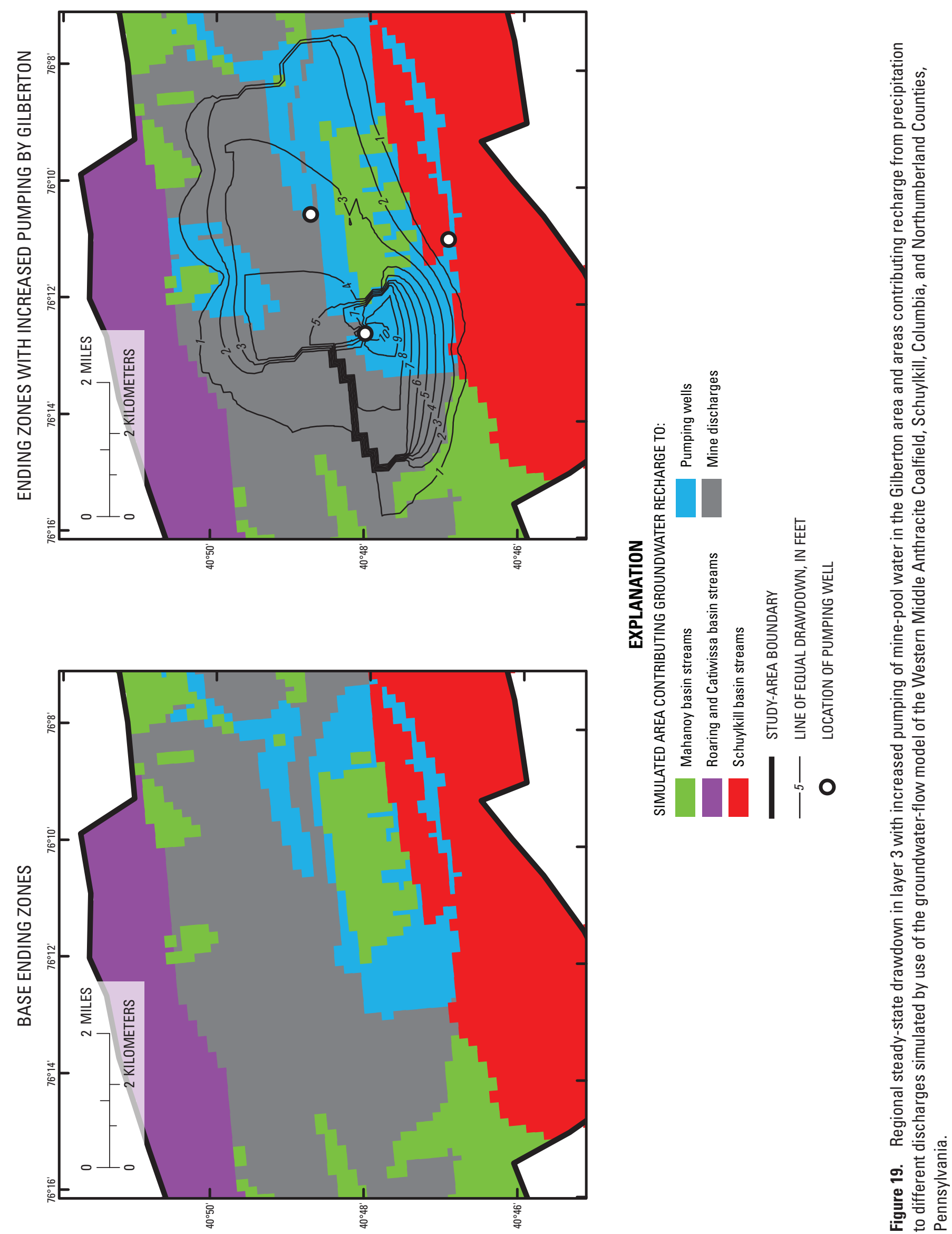
Table 9. Water budget for increased pumping from mine pool in Gilberton area simulated by use of the groundwater-flow model of the Western Middle Anthracite Coalfield, Schuylkill, Columbia, and Northumberland Counties, Pennsylvania.

\begin{tabular}{|c|c|c|c|}
\hline Source of inflow & $\begin{array}{c}\text { Rate } \\
\text { (cubic feet per second) }\end{array}$ & & \\
\hline Recharge & 350.3 & & \\
\hline Source of outflow & $\begin{array}{c}\text { Rate } \\
\text { (cubic feet per second) }\end{array}$ & $\begin{array}{l}\text { Percent of } \\
\text { total outflow }\end{array}$ & $\begin{array}{l}\text { Change in percent of } \\
\text { total outflow }\end{array}$ \\
\hline Net discharge to streams, excluding mine discharges & 196.2 & 56 & -0.4 \\
\hline Stream losses & 7.7 & & \\
\hline Mine discharge & 137.9 & 39.4 & -2.7 \\
\hline Pumping wells & 16.2 & 4.6 & 3.1 \\
\hline
\end{tabular}

${ }^{1}$ Change in percent of total outflow from current-conditions scenario (table 8).

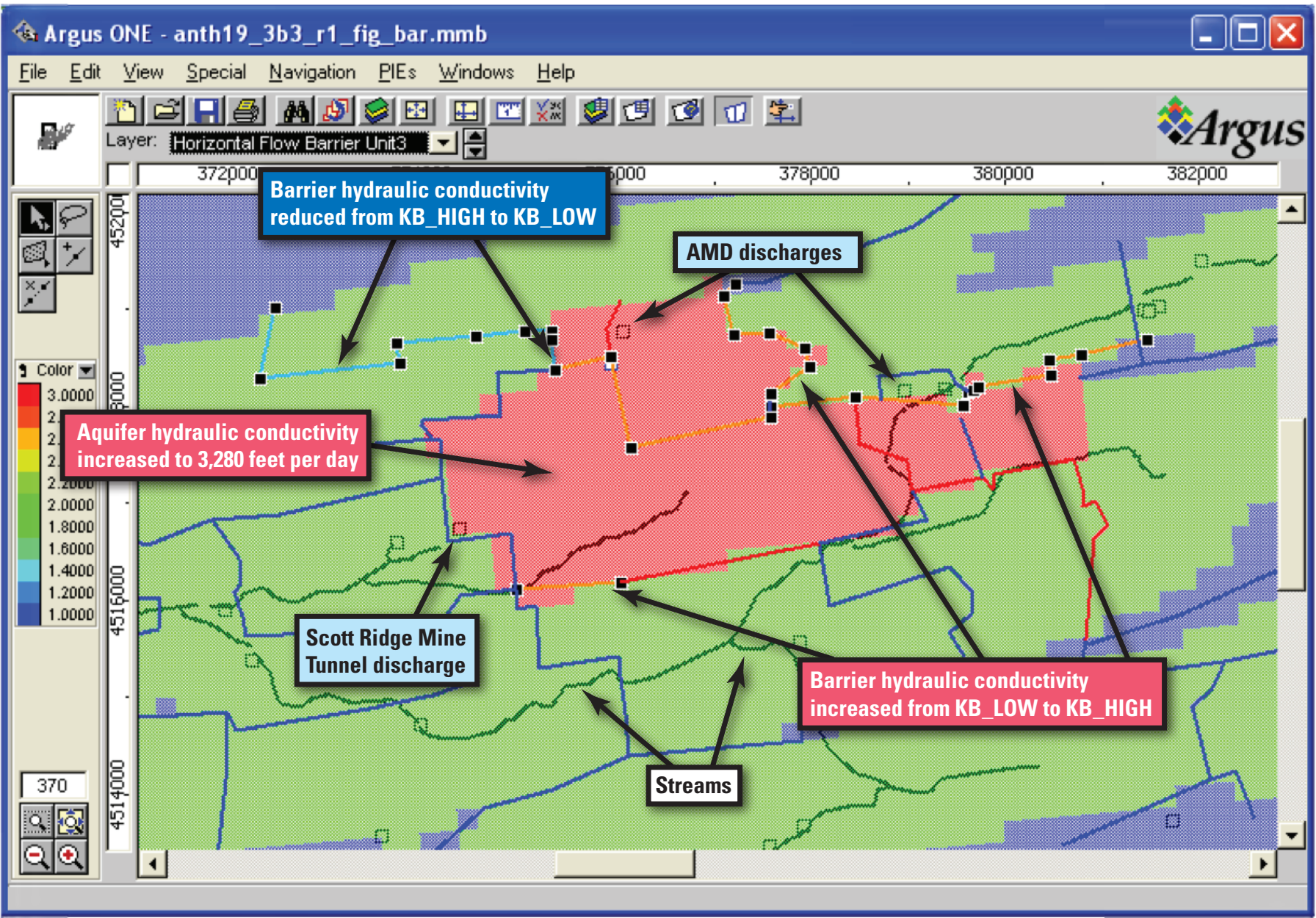

Figure 20. Modifications to mine-barrier hydraulic conductivity for alternative groundwater-flow model for the Western Middle Anthracite Coalfield, Schuylkill, Columbia, and Northumberland Counties, Pennsylvania. This annotated screenshot of the model preprocessor shows mine barriers with low (blue and light blue lines) and high (red and orange lines) hydraulic conductivity, mine-pool discharge locations, streams, and a color map of model layer 3, the mine layer, showing unmined areas (blue shading), mined areas (green shading), and mined areas with aquifer hydraulic conductivity increased to 3,280 feet per day (red shading). Use of tradenames for identification only. 


\section{Limitations of the Preliminary Model Results}

Because the purpose of this report was to develop a preliminary model of groundwater flow, the limitations of the results presented are substantial and need to be recognized. Portions of this section are drawn directly from the report by Risser (2006), which describes a similar preliminary model study. Fundamentally, the study was conducted with readily available data sets and was designed to be a "first cut" for demonstrating the usefulness of groundwater modeling for simulating current conditions and the potential effects of increased pumping from the mine pool. A thorough evaluation of the conceptual model, analysis of model sensitivity, and determination of the effects of boundary conditions has not been conducted.

The groundwater-flow model is based on a simplified conceptualization of steady-state groundwater flow in aquifers characterized by mining voids and fractured bedrock. Although there was reasonably good agreement between measured and simulated water levels and groundwater discharge as viewed on a regional perspective, the poor agreement of measured water levels when viewed at the local scale may be an indication that the extreme heterogeneity of the flooded mines, barriers, and overlying fractured rock is not being well represented by the model at the local scale.

Several important assumptions were made about groundwater recharge in the preliminary modeling that directly affect the water budgets and size of the simulated areas contributing groundwater recharge to the pumping wells. Recharge to the groundwater system was assumed to be spatially and temporally uniform. Groundwater recharge rates probably vary in the study area, especially between mined areas, surface mine pits and spoil piles, and undisturbed areas. In addition, the magnitude of groundwater recharge to the fractured rocks and mine pools from infiltration of streamflow is not well known, but the streamflow data suggest that locally, streamflow leakage is a major source of recharge in some areas.

Results of model simulations were shown to be most sensitive to recharge, hydraulic conductivity of the shallow parts of the aquifer, and effective hydraulic conductivity of the flooded mines and barriers. The effect of changing values for these hydrologic properties was not thoroughly tested in this preliminary study. Use of water levels from wells outside the mined area, and from shallow parts of the aquifer, are suggested to improve the model accuracy in these areas.

Because the model is steady-state, no information is available from the simulations about the storage capacity of the mine pools. The storage coefficient represents the change in water volume stored in the aquifer due to a change in the hydraulic head. Transient (non-steady-state) simulation of the effects of seasonal changes in recharge or changes in pumping rates, along with measurements of contemporaneous changes in water levels and streamflow, could be used to estimate the effective storage coefficient for the mine pool and fractured-rock aquifer. Analysis of precipitation, continuous water levels, and continuous discharge rates can also be used, at least qualitatively, to characterize mine-pool storage (for example, Hawkins and Dunn, 2007; Sahu and others, 2009). Calibration of this groundwater-flow model using similar transient data could provide a quantitative estimate of the storage capacity of the mine pool, independent of estimates of porosity or thickness of mine openings after subsidence.

The data used for adjustment of the model were of variable quality, but for preliminary simulations, the strategy was to use available data on mine-pool water levels and representative streamflow measurements. Mine-discharge flow rates were not used for model calibration. The only weighting of measurements was that to account for different units of measurement between water levels and flows, and this was done so that the total model error was approximately half due to water-level errors and half due to flow errors. A more rigorous weighting of the observed data may help provide better results for aquifer parameters. Measurements at additional locations could allow for additional detail in the model parameters, such as having multiple zones of hydraulic conductivity. Model calibration indicated that the spatial variability in aquifer parameters is not well defined.

An inherent limitation of the model is in the assumption that the hydraulic properties of fractures and flooded mines are represented by an equivalent set of hydraulic properties for a porous medium. The continuum approach is usually adequate for simulating steady-state groundwater flux at large scales incorporating numerous fractures but may be invalid at the local scale if only a few discrete fractures or conduits control groundwater flow paths. In the groundwater-flow model, mine pools having high transmissivity has been theorized and were simulated explicitly in the model; however, many other zones of preferential flow may exist that were not explicitly included. In particular, discrete flow paths from underground mines to surface discharges are approximated as stream boundary conditions within the mines, and without explicit simulation of flow to surface discharges, which may occur through small high-permeability features.

\section{Estimated Groundwater Volume and Distribution}

For the current study, the total volume of water in the mine pools of the Western Middle Anthracite Coalfield was estimated to be $220 \mathrm{Bgal}$, or $675,000 \mathrm{ac}-\mathrm{ft}$, which is 3.1 times greater than the estimate of Reed and others (1987) and 5.8 times greater than the estimate of Ash and others (1949). For all these estimates, the porosity factor of 0.40 , or 40 percent of the original volume of coalbeds within the flooded mine area, is used to account for unmined coal within the mine workings (pillars) plus subsidence, backfilling, and other 
factors that cause the mine-pool volume (water-filled void volume) to be less than the volume of coal and associated rock that was originally mined.

Ash and others (1949) reported that the underground mine pools of the Western Middle Anthracite Coalfield contained approximately $38 \mathrm{Bgal}$, or 117,000 ac-ft, of water (table 10). For this estimate, Ash and others (1949, p. 41-43) multiplied the estimated cumulative thickness of all the coalbeds mined within the mine-pool area by the factor of 0.40 . At the time of this estimate, extensive areas were not flooded because more than a dozen underground mines were using large pumps to dewater the active workings. After these remaining mines closed and the abandoned workings filled with water, establishing a new groundwater table, Reed and others (1987) estimated the underground mines contained approximately $71 \mathrm{Bgal}$, or 218,000 ac-ft, of water. In their updated estimate of the volume of the mine pools of the Western Middle Anthracite Coalfield, Reed and others (1987) adopted the estimates of Ash and others (1949) for collieries where the water level had remained constant from 1949 to 1975 , or increased the volume estimate if the water level in 1975 was greater than that in 1949. Although they did not explain how the updated volumes were computed, the estimate of mine-pool volume by Reed and others (1987) is 38 percent of the total volume of underground voids ( 25 billion cubic feet $=187 \mathrm{Bgal}$ ) reported for the coalfield.

The current estimate of the mine-pool volume was computed using the groundwater-flow model and a simplified conceptual model of the coal-bearing strata and the geologic structure of the study area. The preprocessor used for construction of the groundwater-flow model was used as a computational GIS to discretize the coalfield into three-dimensional finite difference blocks. The coalbeds and noncoal interbeds were included in model layer 3 . The cumulative thickness of the coalbeds beneath the water table and within the mined zone was computed to estimate the mine-pool volume. The altitude of the water table, computed by the groundwater model described above, is the model-simulated hydraulic head in model layer 3 and varies from cell to cell across the area.

To account for variability in the depth or altitude of the mined coal within the study area, only the coalbeds above the bottom of the Buck Mountain coalbed (fig. 4) or the deepest mining in a MCU (table 4), whichever was a higher altitude, were considered. Thus, the mine-pool volume does not include mined strata above the water table, and it does not include groundwater in deep, unmined strata.

Although the thicknesses of the coalbeds and strata between the coalbeds were assumed to be uniform throughout the study area (table 1), an adjustment factor was used to account for variations in the dip of the strata. To convert the thickness of a dipping bed to a vertical thickness, the thickness was divided by the cosine of the dip angle. For the preliminary calculations presented here, the dip angle was approximated from the generalized structure contours (fig. 4), and the assumed dip angle is shown in figure 21 . The actual dip is highly variable because of the complex geologic structure. A refined hydrogeologic model incorporating additional details could be constructed from cross sections and mine maps, but that effort was beyond the scope of the present study.

If a porosity factor smaller than 40 percent was used, the volume estimate would decrease proportionally. For example, Hawkins and Dunn (2007) described a bituminous mine with 11 percent water-filled porosity, despite reported extraction of 63 percent of the coal within the mine area. Using a porosity factor of 0.11 instead of 0.40 , the current estimate of the minepool volume would be $60 \mathrm{Bgal}$ (table 11), which is smaller than that estimated by Reed and others (1987).

Using the estimated volumes and outflow rates for the MCUs in the study area, the average estimated groundwater residence times within each of the MCUs were estimated to range from 0.50 to 6.5 years for a porosity of 0.40 or from 0.14 to 1.9 years for a porosity factor of 0.11 (table 11). Because the residence time is the volume divided by the outflow rate, the residence time for a given outflow rate decreases proportionally with the volume or porosity. Reed and others (1987) demonstrated that the water discharged from the mines in the study area becomes more mineralized as it moves from one mine to the next, suggesting progressively longer traveltime and longer contact with rocks. These authors also demonstrated that groundwater within the flooded mines of the study area tends to be stratified, with less mineralized (younger) water in upper sections and more mineralized (older) water in deeper sections of boreholes. Thus, although the average residence time is useful to indicate the typical turnover time of water stored in a MCU, the actual residence times of the molecules of water in any volume may be widely distributed. Water residing in the rock matrix, or in low-permeability fractures, may be moving very slowly, or only by diffusion, whereas water in open voids or high-permeability fractures may move many feet in a single day.

\section{Uncertainty in Estimates of Mine-Pool Volume}

Estimation of the mine-pool volume for the study area requires knowledge of the volumetric porosity and the geometric configuration of the flooded mine workings. Uncertainty in the data on the volumes of mine voids, the groundwater levels in all the mines, and the depth and extent of mining leads to uncertainty in the estimate of the mine-pool volume. Ash and others (1949) justified an estimate of 0.40 for the water-filled fraction of the abandoned mines during the period of active mining. However, as explained by Hawkins and Dunn (2007), the actual porosity of the flooded, abandoned mine workings could be much smaller than initial estimates of coal removed because of post-mining subsidence. Thus, given the uncertainty in the porosity factor, the volume of water stored in the underground mines is estimated to range from 60 to $220 \mathrm{Bgal}$. 


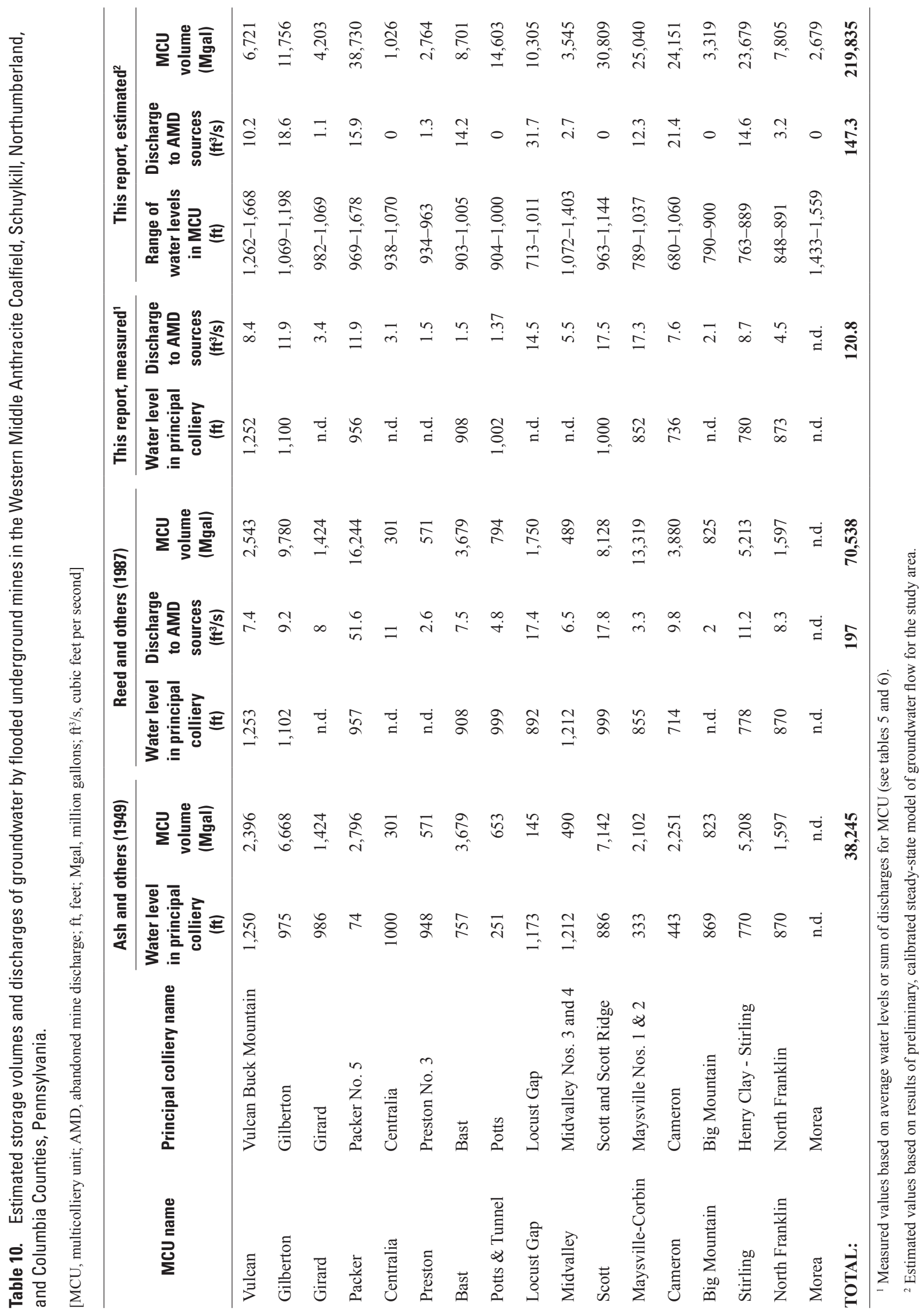




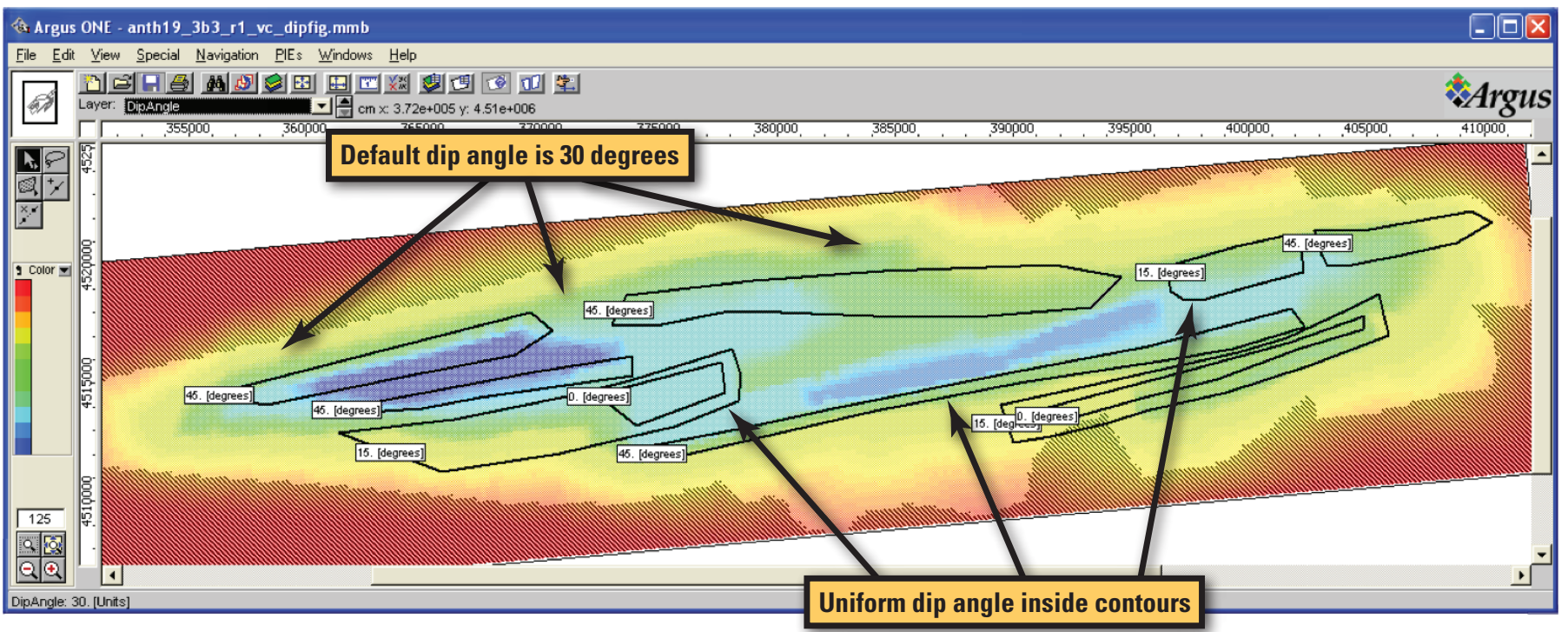

Figure 21. Generalized dip angles for use in estimating mine-pool volumes using a hydrogeologic model for the Western Middle Anthracite Coalfield, Schuylkill, Columbia, and Northumberland Counties, Pennsylvania. This screenshot of the model preprocessor shows uniform dip angle zones and the color map is the altitude of the bottom of the Buck Mountain Formation from low (blue shading) to high (red shading).

Table 11. Estimated storage volumes and average residence times of groundwater in the mine pools considering different porosities for mined coalbeds in the Western Middle Anthracite Coalfield, Schuylkill, Northumberland, and Columbia Counties, Pennsylvania, 1999-2001.

[MCU, multicolliery unit; $\mathrm{ft}^{3} / \mathrm{s}$, cubic feet per second; Bgal, billion gallons; yr, year]

\begin{tabular}{|c|c|c|c|c|c|c|c|c|}
\hline \multirow[b]{2}{*}{ MCU name } & \multirow[b]{2}{*}{$\begin{array}{l}\text { Total } \\
\text { outflow } \\
\text { rate } \\
\text { (cfs) }\end{array}$} & \multicolumn{3}{|c|}{ Outflow rate to: } & \multicolumn{2}{|c|}{ Porosity factor $=0.40$} & \multicolumn{2}{|c|}{ Porosity factor $=0.11$} \\
\hline & & $\begin{array}{l}\text { Wells } \\
\left(\mathrm{ft}^{3} / \mathrm{s}\right)\end{array}$ & $\begin{array}{c}\text { Mine } \\
\text { discharges } \\
\left(\mathrm{ft}^{3} / \mathrm{s}\right)\end{array}$ & $\begin{array}{l}\text { Other } \\
\text { MCUs or } \\
\text { aquifer } \\
\left(\mathrm{ft}^{3} / \mathbf{s}\right)\end{array}$ & $\begin{array}{c}\text { Mine water } \\
\text { volume } \\
\text { (Bgal) }\end{array}$ & $\begin{array}{c}\text { Average } \\
\text { residence } \\
\text { time of water } \\
\text { (yr) }\end{array}$ & $\begin{array}{c}\text { Mine water } \\
\text { volume } \\
\text { (Bgal) }\end{array}$ & $\begin{array}{c}\text { Average } \\
\text { residence } \\
\text { time of water } \\
\text { (yr) }\end{array}$ \\
\hline Vulcan & 15.34 & 0 & 10.16 & 5.18 & 6.7 & 1.9 & 1.9 & 0.5 \\
\hline Packer & 51.51 & 1.83 & 15.91 & 33.77 & 38.7 & 3.2 & 10.7 & 0.9 \\
\hline Gilberton & 36.01 & 2.67 & 18.62 & 14.72 & 11.8 & 1.4 & 3.2 & 0.4 \\
\hline Centralia & 9.61 & 0 & 0 & 9.61 & 1 & 0.5 & 0.3 & 0.1 \\
\hline Bast & 18.29 & 0 & 14.24 & 4.05 & 8.7 & 2 & 2.4 & 0.6 \\
\hline Preston & 2.99 & 0 & 1.31 & 1.68 & 2.8 & 3.9 & 0.8 & 1.1 \\
\hline Midvalley & 6.85 & 0 & 2.73 & 4.12 & 3.5 & 2.2 & 1 & 0.6 \\
\hline Maysville-Corbin & 40.91 & 0 & 12.27 & 28.64 & 25 & 2.6 & 6.9 & 0.7 \\
\hline Cameron & 48.88 & 0 & 21.45 & 27.43 & 24.2 & 2.1 & 6.6 & 0.6 \\
\hline Big Mountain & 4.74 & 0 & 0 & 4.74 & 3.3 & 3 & 0.9 & 0.8 \\
\hline Stirling & 33.31 & 0 & 14.64 & 18.67 & 23.7 & 3 & 6.5 & 0.8 \\
\hline North Franklin & 5.92 & 0 & 3.22 & 2.7 & 7.8 & 5.6 & 2.2 & 1.5 \\
\hline Morea & 4.3 & 0.89 & 0 & 3.41 & 2.7 & 2.6 & 0.7 & 0.7 \\
\hline TOTAL & 366.36 & 5.39 & 147.32 & 213.65 & 219.8 & & 60.5 & \\
\hline
\end{tabular}




\section{Alternative Method for Determining Volume}

An alternative method for characterizing storage properties of the mine complex including the porosity would be through calibration of a transient model of groundwater flow (Goode and Senior, 2000; Sahu and others, 2009). Changes in hydrologic conditions, such as changes in pumping rate of a well, will cause changes in water levels in the aquifer. The magnitude and rate of water-level changes are dependent on the flow properties, such as hydraulic conductivity, and the storage properties, generally the storage coefficient. Thus, calibration of a transient model to measured water levels after a change in pumping rate can identify both the hydraulic conductivity and the storage coefficient. This is conceptually the same as use of the Theis equation to estimate hydraulic conductivity and storage coefficient from analysis of water-level drawdown after a step change in pumping rate (for example, Freeze and Cherry, 1979; Driscoll, 1986; Kruseman and de Ridder, 1990).

The storage coefficient is the ratio of the change of water volume in a unit volume of aquifer divided by the change in water level or hydraulic head. Under confined conditions, the storage coefficient is small and reflects the storage of water by compression of the solid matrix of the aquifer, which causes an increase in the volumetric porosity. Under unconfined or water-table conditions, the storage coefficient is the specific yield, which approximates the porosity for coarse-grained porous media. In this case, water is stored by the filling of pore space above the water table as that surface rises. The storage coefficient for unconfined conditions is generally orders of magnitude larger than that for confined conditions.

In a flooded coal mine in dipping strata, the water table occurs at a "beach" where the mine voids above this level are filled with air and the voids below this level are filled with water (fig. 22). As the groundwater level rises, void space is filled with water. The storage coefficient is large at the beach, reflecting the ratio of voids to solid rock, and very small below the beach level where the workings are already saturated. In addition, storage between the mined layers is small because of the small primary porosity and low hydraulic conductivity of the unmined rocks. In the schematic illustration (fig. 22), the area of the multicolliery aquifer system that can effectively store water at the water table in the mine pool is a small part of the total area. In the case of the multicolliery mine complexes in the Western Middle Anthracite Coalfield, the overall storage coefficient would reflect all the beaches that occur in the interconnected mine workings within the MCU.

Analogous to conducting an aquifer test, data collection for use in a model for estimation of storage properties would include continuous water levels and measurement of pumping rates and other discharges such as streams. Ideally, the aquifer system would be relatively stable for an antecedent time period. The pumping rate could then be changed and held constant for several days. On the basis of the model results presented here, measurable water-level changes for such a test would only occur in the well-connected voids within a single MCU. Calibration of a transient groundwater-flow model to such data could provide an estimate of the overall storage coefficient for the MCU. This would characterize the rate of change in volume of water stored per unit change in water level. Integrating this over the total mine from the lowest mined level to the current water level would yield the total volume of water stored in the MCU.

\section{Identification of Data Needs}

The following data needs are identified for improving the understanding of regional groundwater flow in the Western Middle Anthracite Coalfield. Portions of this section are drawn directly from the report by Risser (2006), which describes a similar study including identification of data needs.

1. Continuous streamflow and mine-discharge monitoring-Long-term continuous monitoring of streamflow in Shamokin and Mahanoy Creeks would provide a record of the response of the basins to natural climate and landuse changes. Continuous monitoring captures events, such as storms, that are impossible to record with synoptic measurements. Streamgages installed as pairs upstream and downstream from segments that gain base flow from multiple or diffuse mine discharges or that are prone to leakage would allow a determination of gains and losses between streamgages.

2. Synoptic streamflow and mine-discharge measurements - The simulated effect of a large pumping well on the groundwater system is related to the potential for groundwater discharges and streamflow to be captured. Data used for calibration of the model were collected during a period when the pump in the Gilberton Mine shaft was not being operated. Measurements of streamflow and mine discharges during periods of pumping near the average annual base-flow conditions would provide better flow targets for adjusting parameters in the steady-state model.

3. Water-level data - Synoptic measurements of groundwater levels in boreholes and wells in areas bordering the mine pools would improve knowledge of the water-table configuration and provide better groundwater-level data for model adjustments. Ideally, the altitudes of all wells should be surveyed so that an accurate datum is available. Continuous monitoring of water levels in wells near streams and groundwater extraction sites would provide a record of the transient response to natural and anthropogenic events. 


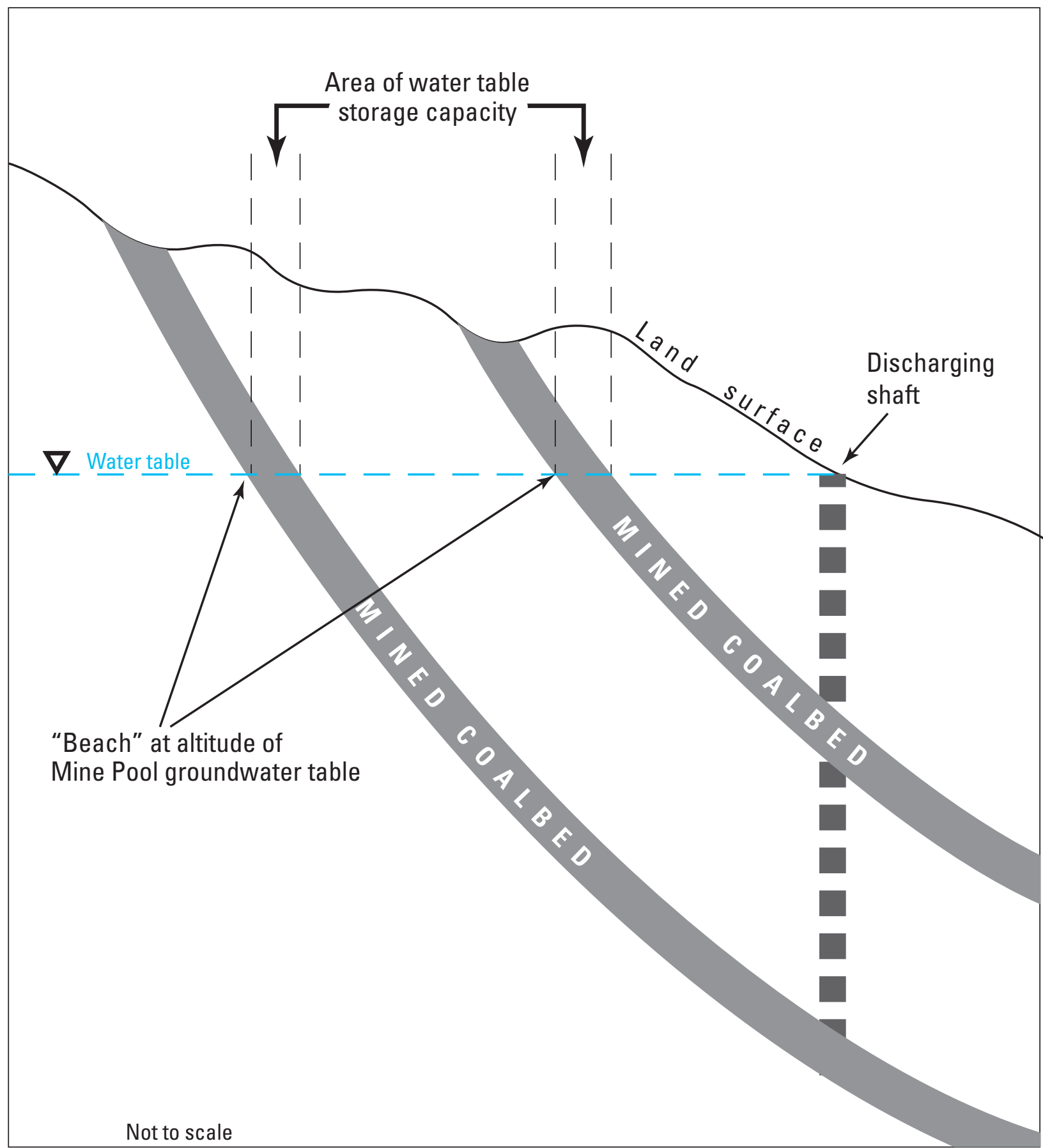

Figure 22. Schematic cross section of flooded mine complex showing the groundwater table in overlying, mined coalbeds and the portion of the surface area of the mined coalbed where water-table storage capacity is effective. For practical purposes, the porosity of unmined strata surrounding the mined coalbeds is considered negligible compared to that of the mined coalbed. Any change in water-table elevation reflects differences in the available storage capacity of the mined coalbed, which varies as a function of the geologic structure (geometry). 
4. Water-use data-Incorporation of historical water withdrawals and discharges would provide a more complete accounting of all terms in the basin water budget. Other data on groundwater pumping for industrial supply and streamflow could be incorporated.

5. Streambed surveys - Surveys of the changes in streamflow and hydraulic gradient beneath stream channels would help establish the extent of gaining and losing reaches under differing hydrologic conditions and season. These surveys can be conducted with a potentiomanometer as described by Winter and others (1988).

6. Tracer studies - Tracer studies are the best method for determining the direction and velocity of groundwater flow. Tracer studies could be conducted on losing reaches of tributaries to Mahanoy Creek or at individual cropfalls or other loss points identified as possible contributing areas for water extracted from the mine pool.

7. Continuous groundwater measurements during stepped pumping tests or recharge events - Continuous measurements of changes in groundwater levels during short-term, transient events would support the calibration of transient simulations to provide an independent estimate of mine-pool storage capacity.

The additional measurements and analysis during transient conditions would help to determine water storage, improve simulations of water budgets, and evaluate the relation between groundwater and surface water.

\section{Summary}

Streamflow and mine-discharge data were evaluated relative to contributing areas to explore possible relations between surface water and groundwater in the $120-\mathrm{mi}^{2}$ area of the Western Middle Anthracite Coalfield. Within this area, a total of 24 coalbeds, with average thicknesses from 2.0 to $7.4 \mathrm{ft}$, have been mined to depths exceeding 2,500 ft below land surface. Most of the coal was removed by underground-mining methods that created an extensive network of interconnected underground voids separated by unmined coal barriers along mine boundaries. After closure, low-lying sections of the mine workings flooded, creating vast underground mine pools that discharge to the surface at topographically low points or from abandoned drainage tunnels.

The Mahanoy and Shamokin Creek Basins were the focus of the study because these basins exhibit extensive hydrologic effects and water-quality degradation from the abandoned mines in their headwaters in the Western Middle Anthracite Coalfield. Base-flow yields on the basis of synoptic streamflow measurements in 1999-2001 indicate that upstream parts of Mahanoy and Shamokin Creeks lose water to the underground mines, but adjacent or downstream sections of Mahanoy and Shamokin Creeks gain base flow. Stream locations with anomalously large yields capture recharge from adjacent basins through the mine pools.

On the basis of mapped mine boundaries, measured groundwater levels, and measured discharge volumes for large sources of abandoned mine drainage (AMD), the 69 mapped mines were grouped as 17 named mine pools or multicolliery hydrologic units (MCUs). The mines that were grouped as a single MCU generally exhibited similar groundwater levels consistent with a high degree of horizontal and vertical interconnections and high permeability. Intact barrier pillars or unmined rock with low permeability separates the MCUs and helps focus groundwater discharge to one or more large AMD outflows associated with each MCU.

A three-dimensional steady-state groundwater-flow model and an associated geographic information system were used to integrate data on the mining features, hydrogeology, and streamflow in the Western Middle Anthracite Coalfield. The preliminary model has very few parameters and does not reflect the actual spatial variability of aquifer properties but was used to test the multicolliery hydrologic model and to illustrate the use of porous-media approximations for this highly complex groundwater system. The numerical groundwater model was developed using MODFLOW-2000 and calibrated to measured water levels and stream base flow, the latter composed primarily of mine discharge at many locations. The calibrated model was used to evaluate the movement of groundwater among adjacent mines. Preliminary simulations were conducted for (1) current conditions and (2) a water table lowered by expanded pumping from the Gilberton Mine pool. Expansion of pumping at Gilberton will lower the water levels, especially close to Gilberton. The simulated water budget indicates that most of the additional pumping is balanced by a reduction in discharges from mines to streams. The simulated groundwater levels illustrate shallow groundwater gradients within an MCU and abrupt changes in water levels between MCUs. Given the simulated groundwater levels, depth of mining, and porosity estimates ranging from 11 to 40 percent for the mined rocks, the water volume in storage in the mines was estimated to range from 60 to $220 \mathrm{Bgal}$, respectively.

The calibrated model supports the conceptual model of the high-permeability MCUs separated by low-permeability barriers and streamflow losses and gains associated with mine-pool infiltration and discharge. However, details of the water-level distribution and the locations and rates of some discharges are not well simulated using the preliminary model. Although example model adjustments showed that improvements in the model calibration were possible by introducing spatial variability in permeability parameters and adjusting barrier properties, more detailed parameterizations have increased uncertainty because of the limited data set. The preliminary model results indicate that the primary result of 
increased pumping from the mine pool would be reduced mine discharge to streams near the pumping wells. The intact barriers limit the spatial extent of mine dewatering. The model and associated estimate of mine-pool volume could be improved with additional water-level and streamflow measurements.

Water budgets and mine pool volume estimates could be improved with additional hydrologic data including streamflow, mine discharge rates, water levels in mines and other parts of the groundwater system, and water-use data. Streamflow, mine discharge, and water levels can be measured continuously with available technology, and such data could substantially improve the understanding of hydraulic connections between mine areas, especially in combination with changes in pumping or large recharge events. Use of transient simulations, calibrated with transient measurements, is suggested to provide an independent estimate of mine-pool storage capacity. Streambed surveys and tracer studies could provide additional information about groundwater/surface-water exchanges and the impact of mine voids on base-flow generation.

\section{References Cited}

21st Century Environment Commission, 1998, Report of the Pennsylvania 21st Century Environment Commission: Pennsylvania Department of Environmental Protection, 92 p., accessed April 6, 2010, at http://www.21stcentury.state. pa.us/2001/report.pdf.

Arndt, H.H., Danilchik, Walter, and Wood, G.H., Jr., 1963a, Geology of anthracite in the western part of the Shamokin quadrangle, Northumberland County, Pennsylvania: U.S. Geological Survey Coal Investigations Map C-47.

Arndt, H.H., Wood, G.H., Jr., and Danilchik, Walter, 1963b, Geology of anthracite in the southern part of the Trevorton quadrangle, Northumberland County, Pennsylvania: U.S. Geological Survey Coal Investigations Map C-48.

Ash, S.H., Eaton, W.L., Hughes, K., Romischer, W.M., and Westfield, J., 1949, Water pools in Pennsylvania anthracite mines: U.S. Bureau of Mines Technical Paper 727, 78 p.

Ash, S.H., Hower, C.S., Kennedy, D.O., and Lesser, W.H., 1953b, Mine pumping plants, Anthracite region of Pennsylvania: U.S. Bureau of Mines Bulletin 531, 151 p.

Ash, S.H., Kennedy, D.O., Link, H.B., and Romischer, W.M., 1953a, Barrier pillars in the Western Middle Field: U.S. Bureau of Mines Bulletin 521, 92 p.

Ash, S.H., and Link, H.B., 1953, Surface-water seepage into anthracite mines in the Western Middle Field: U.S. Bureau of Mines Bulletin 532, 26 p.
Becher, A.E., 1991, Groundwater resources in and near the anthracite basins of Schuylkill and adjacent counties, Pennsylvania: Pennsylvania Geological Survey, 4th ser., Water Resources Report 64, 59 p., 1 plate.

Berg, T.M., Barnes, J.H., Seven, W.D., Skema, V.K., Wilshusen, J.P., and Yannicci, D.S., 1989, Physiographic provinces of Pennsylvania: Pennsylvania Geological Survey, 4th ser., Map 13, scale 1:2,000,000.

Berg, T.M., Edmunds, W.E., Geyer, A.R., Glover, A.D., Hoskins, D.M., MacLachlan, D.B., Root, S.I., Sevon, W.D., and Socolow, A.A., comps., 1980, Geologic map of Pennsylvania: Pennsylvania Geological Survey, 4th ser., Map 1, scale 1:250,000, 3 sheets.

Callaghan, Thomas, Fleeger, G.M., Barnes, Scott, and Dalberto, Albert, 1998, Groundwater flow on the Appalachian Plateau of Pennsylvania, in Brady, K.B.C., Smith, M.W., and Schueck, J., eds., Coal mine drainage prediction and pollution prevention in Pennsylvania: Pennsylvania Department of Environmental Protection, 5600-BK-DEP2256, p. 2.1-2.39.

Carleton, G.B., and Gordon, A.D., 2007, Hydrogeology of, and simulation of ground-water flow in, the Pohatcong Valley, Warren County, New Jersey: U.S. Geological Survey Scientific Investigations Report 2006-5269, 66 p.

Cravotta, C.A., III, 2005, Effects of abandoned coal-mine drainage on streamflow and water quality in the Mahanoy Creek basin, Schuylkill, Columbia, and Northumberland Counties, Pennsylvania, 2001: U.S. Geological Survey Scientific Investigations Report 2004-5291, 60 p., 4 appendixes.

Cravotta, C.A., III, and Kirby, C.S., 2004, Effects of abandoned coal-mine drainage on streamflow and water quality in the Shamokin Creek basin, Northumberland and Columbia Counties, Pennsylvania, 1999-2001: U.S. Geological Survey Water-Resources Investigations Report 03-4311, $58 \mathrm{p}$.

Danilchik, Walter, Arndt, H.H., and Wood, G.H., Jr., 1962, Geology of anthracite in the eastern part of the Shamokin quadrangle, Northumberland County, Pennsylvania: U.S. Geological Survey Coal Investigations Map C-46.

Danilchik, Walter, Rothrock, H.E., and Wagner, H.C., 1955, Geology of anthracite in the western part of the Shenandoah quadrangle, Pennsylvania: U.S. Geological Survey Coal Investigations Map C-21.

Driscoll, F.G., 1986, Groundwater and wells (2nd ed.): St. Paul, Minn., Johnson Division, 1,089 p. 
Eggleston, J.R., Kehn, T.M., and Wood, G.H., Jr., 1999, Anthracite, in Schultz, C.H., ed., The geology of Pennsylvania: Pennsylvania Geological Survey, 4th series, Special Publication 1, p. 458-469.

Freeze, R.A., and Cherry, J.A., 1979, Groundwater: Englewood Cliffs, N.J., Prentice-Hall, Inc., 604 p.

Gannett Fleming Corddry and Carpenter, Inc., 1972, Operation Scarlift project no. SL-113-Mine drainage abatement measures for the Shamokin Creek Watershed: Harrisburg, Pa., Gannett Fleming Corddry and Carpenter, Inc.

Goode, D.J., and Senior, L.A., 2000, Simulation of aquifer tests and groundwater flowpaths at the local scale in fractured shales and sandstones of the Brunswick Group and Lockatong Formation, Lansdale, Montgomery County, Pennsylvania: U.S. Geological Survey Open-File Report 00-97, $46 \mathrm{p}$.

Growitz, D.J., Reed, L.A., and Beard, M.M., 1985, Reconnaissance of mine drainage in the coal fields of eastern Pennsylvania: U.S. Geological Survey Water-Resources Investigations Report 83-4274, 54 p.

Haley, B.R., Arndt, H.H., Rothrock, H.E., and Wagner, H.C., 1953, Geology of anthracite in the western part of the Ashland quadrangle, Pennsylvania: U.S. Geological Survey Coal Investigations Map C-13.

Haley, B.R., Arndt, H.H., Rothrock, H.E., and Wagner, H.C., 1954, Geology of anthracite in the eastern part of the Ashland quadrangle, Pennsylvania: U.S. Geological Survey Coal Investigations Map C-14.

Harbaugh, A.W., Banta, E.R., Hill, M.C., and McDonald, M.G., 2000, MODFLOW-2000, the U.S. Geological Survey modular groundwater flow model-User guide to modularization concepts and the groundwater flow process: U.S. Geological Survey Open-File Report 00-92, 121 p.

Harlow, G.E., Jr., and LeCain, G.D., 1993, Hydraulic characteristics of, and ground-water flow in, coal-bearing rock of southwestern Virginia: U.S. Geological Survey WaterSupply Paper 2388, 37 p.

Hawkins, J.W., and Dunn, M., 2007, Hydrologic characteristics of a 35-year-old underground mine pool: Mine Water and the Environment, v. 26, p. 150-159.

Hill, M.C., Banta, E.R., and Harbaugh, A.W., 2000, MODFLOW-2000, the U.S. Geological Survey modular groundwater flow model-User guide to the observation, sensitivity, and parameter-estimation processes and three post-processing programs: U.S. Geological Survey OpenFile Report 00-184, 209 p.
Hsieh, P.A., and Freckleton, J.R., 1993, Documentation of a computer program to simulate horizontal-flow barriers using the U.S. Geological Survey modular three-dimensional finite-difference ground-water flow model: U.S. Geological Survey Open-File Report 92-477, 32 p.

Kehn, T.M., and Wagner, H.C., 1955, Geology of anthracite in the eastern part of the Shenandoah quadrangle, Pennsylvania: U.S. Geological Survey Coal Investigations Map C-19.

Kruseman, G.P., and de Ridder, N.A., 1990, Analysis and evaluation of pumping test data: Wageningen, the Netherlands, International Institute for Land Reclamation and Improvement, Publication 47, $377 \mathrm{p}$.

Lewis-Brown, J.C., Rice, D.E., Rosman, Robert, and Smith, N.P., 2005, Hydrogeological framework, ground-water quality, and simulation of ground-water flow at the Fair Lawn Well Field superfund site, Bergen County, New Jersey: U.S. Geological Survey Scientific Investigations Report 2004-5280, 109 p.

Marsh, Ben, 1987, Continuity and decline in the anthracite towns of Pennsylvania: Annals of the Association of American Geographers, v. 77, p. 337-352.

Maxwell, J.A., and Rothrock, H.E., 1955, Geology of anthracite in the western part of the Delano quadrangle, Pennsylvania: U.S. Geological Survey Coal Investigations Map C-25.

McCoy, K.J., Donovan, J.J., and Leavitt, B.R., 2006, Horizontal hydraulic conductivity estimates for intact coal barriers between closed underground mines: Environmental \& Engineering Geoscience, v. 12, no. 3, p. 273-282.

National Climatic Data Center, 2010, U.S. Department of Commerce, National Environmental Satellite, Data, and Information Service, accessed February 22, 2010, at http:// www.ncdc.noaa.gov/oa/ncdc.html.

Pollock, D.W., 1994, User's guide for MODPATH/MODPATH-PLOT, VERSION 3-A particle tracking postprocessing package for MODFLOW, the U.S. Geological Survey finite-difference groundwater flow model: U.S. Geological Survey Open-File Report 94-464, 249 p.

Prudic, D.E., 1989, Documentation of a computer program to simulate stream-aquifer relations using a modular, finite-difference, groundwater flow model: U.S. Geological Survey Open-File Report 88-729, 113 p.

Reed, L.A., Beard, M.M., and Growitz, D.J., 1987, Quality of water in mines in the western middle coal field, anthracite region, east-central Pennsylvania: U.S. Geological Survey Water-Resources Investigations Report 64, 51 p. 
Risser, D.W., 2006, Simulated water budgets and groundwater/surface-water interactions in Bushkill and parts of Monocacy Creek watersheds, Northampton County, Pennsylvania-A preliminary study with identification of data needs: U.S. Geological Survey Open-File Report 2006-1143, $31 \mathrm{p}$.

Risser, D.W., Conger, R.W., Ulrich, J.E., and Asmussen, M.P., 2005, Estimates of groundwater recharge based on streamflow-hydrograph methods-Pennsylvania: U.S. Geological Survey Open-File Report 2005-1333, 30 p.

Rothrock, H.E., Wagner, H.C., and Haley, B.R., 1950, Geology of anthracite in the west-central part of the Mount Carmel quadrangle, Pennsylvania: U.S. Geological Survey Investigations Map C-3.

Rothrock, H.E., Wagner, H.C., Haley, B.R., and Arndt, H.H., 1951a, Geology of anthracite in the southwestern part of the Mount Carmel quadrangle, Pennsylvania: U.S. Geological Survey Investigations Map C-7.

Rothrock, H.E., Wagner, H.C., Haley, B.R., and Arndt, H.H., 1951b, Geology of anthracite in the east-central part of the Mount Carmel quadrangle, Pennsylvania: U.S. Geological Survey Coal Investigations Map C-10.

Rothrock, H.E., Wagner, H.C., Haley, B.R., and Arndt, H.H., 1953, Geology of anthracite in the southeastern part of the Mount Carmel quadrangle, Pennsylvania: U.S. Geological Survey Coal Investigations Map C-12.

Rutledge, A.T., 1998, Computer programs for describing the recession of ground-water discharge and for estimating mean ground-water recharge and discharge from streamflow data-Update: U.S. Geological Survey Water-Resources Investigations Report 98-4148, 43 p.

Saad, D.A., and Cravotta, C.A., III, 1991, Modeling of ground-water flow along a cross section through a reclaimed surface coal mine in western Pennsylvania (abs.), in Proceedings of the 1991 National Meeting of the American Society for Surface Mining and Reclamation, May 14-17, 1991, Durango, Co.: Princeton, W.Va., American Society for Surface Mining and Reclamation, p. 545. (Also available at http://www.techtransfer.osmre.gov/NTTMainSite/Library/ proceed/asmr91/session6.pdf)

Sahu, Parameswar, Lopez, D.L., and Stoertz, M.W., 2009, Using time series analysis of coal mine hydrographs to estimate mine storage, retention time, and mine-pool interconnection: Mine Water and the Environment, v. 28, p. 194-205.
Sanders \& Thomas, Inc., 1975, Operation Scarlift project no. SL-197, Mahanoy Creek mine drainage pollution abatement project: Harrisburg, Pa., Sanders \& Thomas, Inc. Engineers, 125 p., 1 appendix, 2 plates.

Susquehanna River Basin Commission, 2005, WMPI PTY, L.L.C.-Groundwater withdrawal of $7.000 \mathrm{mgd}$ (30-day average) and consumptive water use of up to $3.470 \mathrm{mgd}$ (peak day) for the gasification and liquefaction of coal waste, and for the ancillary generation of steam and electricity, Mahanoy and West Mahanoy Townships, Schuylkill County, Pennsylvania: Docket No. 20050905, September 14, 2005, accessed April 21, 2010, at http://www.srbc.net/ wrp/Details.aspx?ID=3065.

U.S. Geological Survey, 2004, National elevation data set, accessed April 4, 2009, at http://ned.usgs.gov/.

U.S. Geological Survey, 2009, Pennsylvania StreamStats, accessed November 22, 2009, at http://water.usgs.gov/osw/ streamstats/pennsylvania.html.

Veil, J.A., Kupar, J.M., and Puder, M.G., 2003, Use of mine pool water for power plant cooling: Argonne National Laboratory, final report to U.S. Department of Energy National Energy Technology Laboratory under contract W-31-109Eng-38: 62 p., accessed February 20, 2010, at http://www. netl.doe.gov/technologies/coalpower/ewr/pubs/mine\%20 pool\%20report\%20FINAL_1.pdf)

Winston, R.B., 2000, Graphical user interface for MODFLOW, Version 4: U.S. Geological Survey Open-File Report 00-315, 27 p.

Winter, T.C., LaBaugh, J.W., and Rosenberry, D.O., 1988, The design and use of a hydraulic potentiomanometer for direct measurement of differences in hydraulic head between groundwater and surface water: Limnology and Oceanography, v. 33, no. 5, p. 1,209-1,214.

Wood, C.R., 1996, Water quality of large discharges in the anthracite region of eastern Pennsylvania: U.S. Geological Survey Water-Resources Investigations Report 95-4243, $68 \mathrm{p}$.

Wood, G.H., Jr., Kehn, T.M., and Eggleston, J.R., 1986, Deposition and structural history of the Pennsylvania Anthracite region, in Lyons, P.C., and Rice, C.L., eds., Paleoenvironmental and tectonic controls in coal-forming basins of the United States: Geological Society of America Special Paper 210, p.

Wyrick, G.G., and Borchers, J.W., 1981, Hydrologic effects of stress-relief fracturing in an Appalachian valley: U.S. Geological Survey Water-Supply Paper 2177, 51 p. 
(This page intentionally left blank.) 
Tables 3 and 5 
Table 3. Site descriptions and flow rates of abandoned mine discharges in the Western Middle Anthracite Coalfield, Schuylkill, Columbia, and Northumberland Counties, Pennsylvania, 1999-2001.

[USGS, U.S. Geological Survey; ft, feet above National Geodetic Vertical Datum of 1929; ft 3 /s, cubic feet per second; colored shading identifies sites with maximum discharge greater than $1 \mathrm{ft}^{3} / \mathrm{s}$ and are considered in numerical flow model: yellow, Shamokin Creek; green, Mahanoy Creek; red, Schuylkill River]

\begin{tabular}{|c|c|c|c|c|c|c|c|}
\hline \multirow{2}{*}{$\begin{array}{c}\text { Local } \\
\text { identification } \\
\text { number }\end{array}$} & \multirow[b]{2}{*}{ Local name } & \multirow{2}{*}{$\begin{array}{l}\text { USGS station } \\
\text { number }\end{array}$} & \multirow[b]{2}{*}{ Latitude } & \multirow[b]{2}{*}{ Longitude } & \multirow{2}{*}{$\begin{array}{c}\text { Altitude } \\
\text { (ft) }\end{array}$} & \multicolumn{2}{|c|}{ Discharge $^{1}$} \\
\hline & & & & & & $\begin{array}{c}\text { Minimum } \\
\left(\mathrm{ft}^{3} / \mathrm{s}\right)\end{array}$ & $\begin{array}{c}\text { Maximum } \\
\left(\mathrm{ft}^{3} / \mathrm{s}\right)\end{array}$ \\
\hline SR01 & N Branch Shamokin Creek at Aristes & 01554200 & 40.8247 & -76.3576 & 1,760 & 0.01 & 0.2 \\
\hline SR02 & Mid Valley Mine seep & 404917076222101 & 40.8218 & -76.3727 & 1,520 & 0.04 & 0.1 \\
\hline SR04 & Mid Valley Mine Tunnel 4 & 404905076235501 & 40.8181 & -76.3990 & 1,290 & 0.5 & 1.3 \\
\hline SR05A & Mid Valley Mine Tunnel overflow & 01554260 & 40.8137 & -76.4042 & 1,220 & 0 & 1.4 \\
\hline SR05B & Mid Valley Mine Tunnel & 404848076242401 & 40.8135 & -76.4060 & 1,220 & 2.7 & 5 \\
\hline SR06 & Sayre-Sioux Mine discharge & 404757076231201 & 40.7992 & -76.3867 & 1,200 & 0.02 & 0.02 \\
\hline SR11 & Alaska Mine seep & 404656076265001 & 40.7822 & -76.4474 & 1,060 & 0 & 0.25 \\
\hline SR12 & Excelsior Mine pit overflow & 404625076293701 & 40.7738 & -76.4934 & 970 & 7.2 & 14 \\
\hline SR13 & Locust Gap Mine seep SR13 & 404549076295301 & 40.7635 & -76.4981 & 1,440 & 0.02 & 0.02 \\
\hline SR15 & Corbin Water Level Drift & 404646076305301 & 40.7795 & -76.5142 & 890 & 0.92 & 2.5 \\
\hline SR19 & Scott Ridge Mine Tunnel & 404739076291901 & 40.7921 & -76.4891 & 1,000 & 9.4 & 19 \\
\hline SR20 & Colbert Mine breach & 404726076294101 & 40.7907 & -76.4967 & 970 & 1.6 & 1.9 \\
\hline $\mathrm{SR} 21$ & Maysville Mine Borehole & 404703076305201 & 40.7842 & -76.5176 & 850 & 0.56 & 4.3 \\
\hline SR22A & Royal Oak Mine seep SR22A & 404657076320501 & 40.7824 & -76.5350 & 790 & 0.01 & 0.22 \\
\hline SR31-3 & Greenough Mine discharge & 404838076281001 & 40.8107 & -76.4695 & 1,300 & 0.01 & 0.04 \\
\hline SR36A & Luke Fiddler Mine discharge & 404725076323501 & 40.7905 & -76.5431 & 800 & 0 & 0 \\
\hline SR36B & Royal Oak Mine discharge SR36B & 404724076324201 & 40.7903 & -76.5452 & 750 & 0.01 & 0.02 \\
\hline SR37 & Bear Valley Mine discharge SR37 & 404631076373001 & 40.7755 & -76.6253 & 1,110 & 0 & 0.01 \\
\hline SR38A & Bear Valley Mine seep SR38A & 404754076372801 & 40.7817 & -76.6255 & 1,180 & 0.03 & 0.04 \\
\hline SR39 & Bear Valley strip pool overflow & 404642076373001 & 40.7785 & -76.6248 & 1,010 & 0.01 & 0.07 \\
\hline SR40B & Bear Valley Mine discharge SR40B & 404636076373501 & 40.7770 & -76.6266 & 1,020 & 0 & 0.04 \\
\hline SR40C & Bear Valley Mine discharge SR40C & 404637076373401 & 40.7772 & -76.6261 & 1,020 & 0.01 & 0.08 \\
\hline SR41 & KMK Coal Co. No. 14 & 404622076364601 & 40.7730 & -76.6129 & 910 & 0 & 0.01 \\
\hline SR42 & Bear Valley Mine N Mtn Tunnel & 404618076365901 & 40.7720 & -76.6157 & 930 & 0.4 & 1.1 \\
\hline SR43 & Bear Valley Mine discharge SR43 & 404618076361001 & 40.7718 & -76.6030 & 940 & 0 & 0.04 \\
\hline
\end{tabular}


Table 3. Site descriptions and flow rates of abandoned mine discharges in the Western Middle Anthracite Coalfield, Schuylkill, Columbia, and Northumberland Counties, Pennsylvania, 1999-2001.-Continued

[USGS, U.S. Geological Survey; ft, feet above National Geodetic Vertical Datum of 1929; $\mathrm{ft}^{3} / \mathrm{s}$, cubic feet per second; colored shading identifies sites with maximum discharge greater than $1 \mathrm{ft}^{3} / \mathrm{s}$ and are considered in numerical flow model: yellow, Shamokin Creek; green, Mahanoy Creek; red, Schuylkill River]

\begin{tabular}{|c|c|c|c|c|c|c|c|}
\hline \multirow{2}{*}{$\begin{array}{c}\text { Local } \\
\text { identification } \\
\text { number }\end{array}$} & \multirow[b]{2}{*}{ Local name } & \multirow[b]{2}{*}{$\begin{array}{c}\text { USGS station } \\
\text { number }\end{array}$} & \multirow[b]{2}{*}{ Latitude } & \multirow[b]{2}{*}{ Longitude } & \multirow[b]{2}{*}{$\begin{array}{c}\text { Altitude } \\
\text { (ft) }\end{array}$} & \multicolumn{2}{|c|}{ Discharge $^{1}$} \\
\hline & & & & & & $\begin{array}{c}\text { Minimum } \\
\left(\mathrm{ft}^{3} / \mathrm{s}\right)\end{array}$ & $\begin{array}{c}\text { Maximum } \\
\left(\mathrm{ft}^{3} / \mathrm{s}\right)\end{array}$ \\
\hline \multicolumn{8}{|c|}{ Shamokin Creek Basin } \\
\hline SR44 & Bear Valley Mine discharge SR44 & 404628076361201 & 40.7746 & -76.6036 & 890 & 0.02 & 0.02 \\
\hline SR45 & Henry Clay Stirling Mine discharge & 404625076352701 & 40.7737 & -76.5909 & 850 & 0 & 0.01 \\
\hline SR47 & Bear Valley Mine discharge SR47 & 404614076351001 & 40.7708 & -76.5862 & 850 & 0 & 0.03 \\
\hline SR48 & Henry Clay Stirling Mine seep SR48 & 404643076344701 & 40.7790 & -76.5789 & 900 & 0.02 & 0.2 \\
\hline SR49 & Henry Clay Stirling Mine pump slope & 404037076340701 & 40.7773 & -76.5681 & 790 & 1.6 & 13 \\
\hline SR51 & Cameron Mine discharge SR51 & 404731076334601 & 40.7938 & -76.5650 & 730 & 0.02 & 0.67 \\
\hline SR53 & Cameron Mine Air Shaft & 404744076335901 & 40.7964 & -76.5657 & 710 & 2.3 & 5 \\
\hline SR54 & Cameron Mine seep & 404748076335701 & 40.7968 & -76.5660 & 800 & 0.01 & 0.01 \\
\hline SR55 & Richards Shaft Mine Drift & 404817076261201 & 40.8056 & -76.4350 & 1,070 & 0 & 6.6 \\
\hline SR56 & Mid Valley Mine discharge & 404848076241801 & 40.8134 & -76.4052 & 1,220 & 0 & 0.01 \\
\hline \multicolumn{8}{|c|}{ Mahanoy Creek Basin } \\
\hline M01 & Vulcan-Buck Mountain Mine Morris Tunnel & 404916076071701 & 40.8160 & -76.1237 & 1,290 & 0 & 0 \\
\hline M02 & Vulcan-Buck Mountain Mine seepage & 404858076072501 & 40.8160 & -76.1237 & 1,290 & 0 & 8.79 \\
\hline M03 & Vulcan-Buck Mountain Mine boreholes & 404855076073501 & 40.8154 & -76.1260 & 1,259 & 2.64 & 5.28 \\
\hline M11 & Girard Mine seepage & 404730076160601 & 40.7918 & -76.2680 & 1,005 & 2.73 & 4.1 \\
\hline M12 & Packer \#5 Mine borehole & 404740076162201 & 40.7945 & -76.2724 & 972 & 3.62 & 5.27 \\
\hline M13 & Packer \#5 Mine breach & 404739076162801 & 40.7943 & -76.2741 & 965 & 5 & 5.8 \\
\hline M17 & Preston Mine \#3 Tunnel overflow & 404725076173401 & 40.7904 & -76.2924 & 960 & 0.67 & 2.23 \\
\hline M18 & Bast Mine Tunnel & 404729076180801 & 40.7919 & -76.3013 & 950 & 0.4 & 0.67 \\
\hline M19 & Centralia Mine tunnel & 404727076192601 & 40.7909 & -76.3236 & 1,090 & 2.43 & 3.86 \\
\hline M20 & Bast Mine Overflow site & 404711076190901 & 40.7864 & -76.3188 & 910 & 0 & 2.23 \\
\hline M21 & Bast Mine Oakland Tunnel & 404706076195401 & 40.7851 & -76.3313 & 900 & 2.3 & 4 \\
\hline M22 & Tunnel Mine seepage to ditch from bank & 404655076195301 & 40.7828 & -76.3315 & 900 & 0.03 & 0.03 \\
\hline M23 & Tunnel Mine discharge from spoil bank & 404650076200201 & 40.7804 & -76.3339 & 900 & 0.03 & 0.03 \\
\hline M24 & Tunnel Mine drain pool area and storage & 404645076201201 & 40.7791 & -76.3365 & 930 & 0.09 & 0.13 \\
\hline
\end{tabular}


Table 3. Site descriptions and flow rates of abandoned mine discharges in the Western Middle Anthracite Coalfield, Schuylkill, Columbia, and Northumberland Counties, Pennsylvania, 1999-2001.-Continued

[USGS, U.S. Geological Survey; ft, feet above National Geodetic Vertical Datum of 1929; $\mathrm{ft}^{3} / \mathrm{s}$, cubic feet per second; colored shading identifies sites with maximum discharge greater than $1 \mathrm{ft}^{3} / \mathrm{s}$ and are considered in numerical flow model: yellow, Shamokin Creek; green, Mahanoy Creek; red, Schuylkill River]

\begin{tabular}{|c|c|c|c|c|c|c|c|}
\hline \multirow{2}{*}{$\begin{array}{l}\text { Local } \\
\text { identification } \\
\text { number }\end{array}$} & \multirow[b]{2}{*}{ Local name } & \multirow{2}{*}{$\begin{array}{l}\text { USGS station } \\
\text { number }\end{array}$} & \multirow[b]{2}{*}{ Latitude } & \multirow[b]{2}{*}{ Longitude } & \multirow{2}{*}{$\begin{array}{c}\text { Altitude } \\
\text { (ft) }\end{array}$} & \multicolumn{2}{|c|}{ Discharge $^{1}$} \\
\hline & & & & & & $\begin{array}{l}\text { Minimum } \\
\left(\mathrm{ft}^{3} / \mathrm{s}\right)\end{array}$ & $\begin{array}{c}\text { Maximum } \\
\left(\mathrm{ft}^{3} / \mathrm{s}\right)\end{array}$ \\
\hline M25 & Tunnel Mine Orchard Drift overflow & 404648076202301 & 40.7800 & -76.3398 & 900 & 0.04 & 0.04 \\
\hline M26 & Potts Mine West breach & 404634076221901 & 40.7762 & -76.3716 & 979 & 0.36 & 1.44 \\
\hline M28 & Lavelle Mine Lavelle slope & 404558076240501 & 40.7661 & -76.4014 & 1,180 & 0.01 & 0.23 \\
\hline M29 & Locust Gap Mine Helfenstein Tunnel & 404504076261201 & 40.7512 & -76.4363 & 710 & 7.29 & 17.2 \\
\hline M30 & Locust Gap Mine Helfenstein seepage & 404515076265201 & 40.7542 & -76.4478 & 1,130 & 0 & 0.09 \\
\hline M31 & Locust Gap Mine Doutyville tunnel & 404435076283801 & 40.7431 & -76.4769 & 730 & 0.99 & 3.52 \\
\hline M34 & N. Franklin Mine bank seepage & 404617076405201 & 40.7715 & -76.6808 & 880 & 0 & 0.02 \\
\hline \multicolumn{8}{|c|}{ Schuylkill River Basin } \\
\hline MC01 & Morea Mine Strip Pool Overflow & 404657079105501 & 40.7825 & -76.1819 & 1,400 & 1.4 & 15 \\
\hline \multicolumn{8}{|c|}{$\begin{array}{l}{ }^{1} \text { Abandoned mine discharge (AMD) sites in the study area were described in previous reports by the U.S. Geological Survey (Growitz and others, 1985; } \\
\text { Reed and others, 1987; Wood, 1996; Cravotta and Kirby, 2004; Cravotta, 2005). Minimum and maximum discharge values for sites in the Shamokin and } \\
\text { Mahanoy Creek Basins are based on two measurements during 1999-2001 (Cravotta and Kirby, 2004; Cravotta, 2005) and for the site in the Schuylkill River } \\
\text { Basin on two measurements in } 1979 \text { and } 1990 \text { (Wood, 1996). }\end{array}$} \\
\hline \multicolumn{8}{|c|}{$\begin{array}{l}{ }^{2} \text { During August } 2000 \text { and March 2001, when other AMD and stream sites in the Mahanoy Creek Basin were sampled by the U.S. Geological Survey, the } \\
\text { Gilberton Mine Pump was not operating and the discharge was dry (Cravotta, 2005). Reed and others (1987, p. 13) indicated that the Gilberton Mine Pump } \\
\text { operates } 40 \text { percent of the time, and thus estimated the flow as } 40 \text { percent of the measured value of } 23 \mathrm{ft}^{3} / \mathrm{s} \text {. The value of } 10.83 \mathrm{ft}^{3} / \mathrm{s} \text { indicated for "maximum } \\
\text { flow rate" during the } 1999-2001 \text { study period corresponds to a discharge rate of } 7 \text { million gallons per day, which approximates the long-term annual average } \\
\text { on the basis of pumping records for 1985-1998 (Susquehanna River Basin Commission, 2005). In } 1979 \text { and 1990, the USGS measured discharges of } 23 \text { and } \\
7.8 \mathrm{ft}^{3} / \mathrm{s} \text {, respectively, for the Gilberton pump (Wood, 1995). }\end{array}$} \\
\hline
\end{tabular}




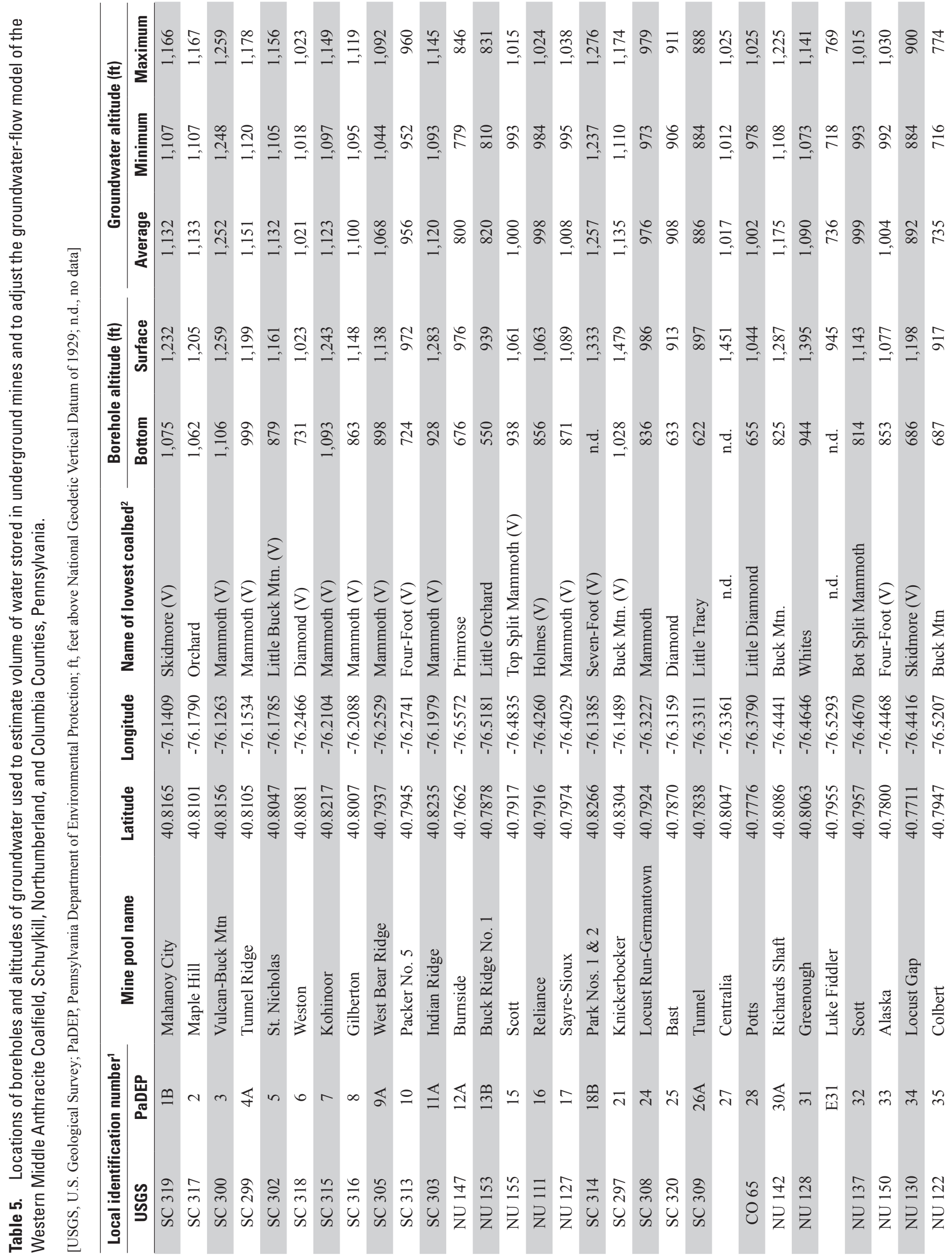




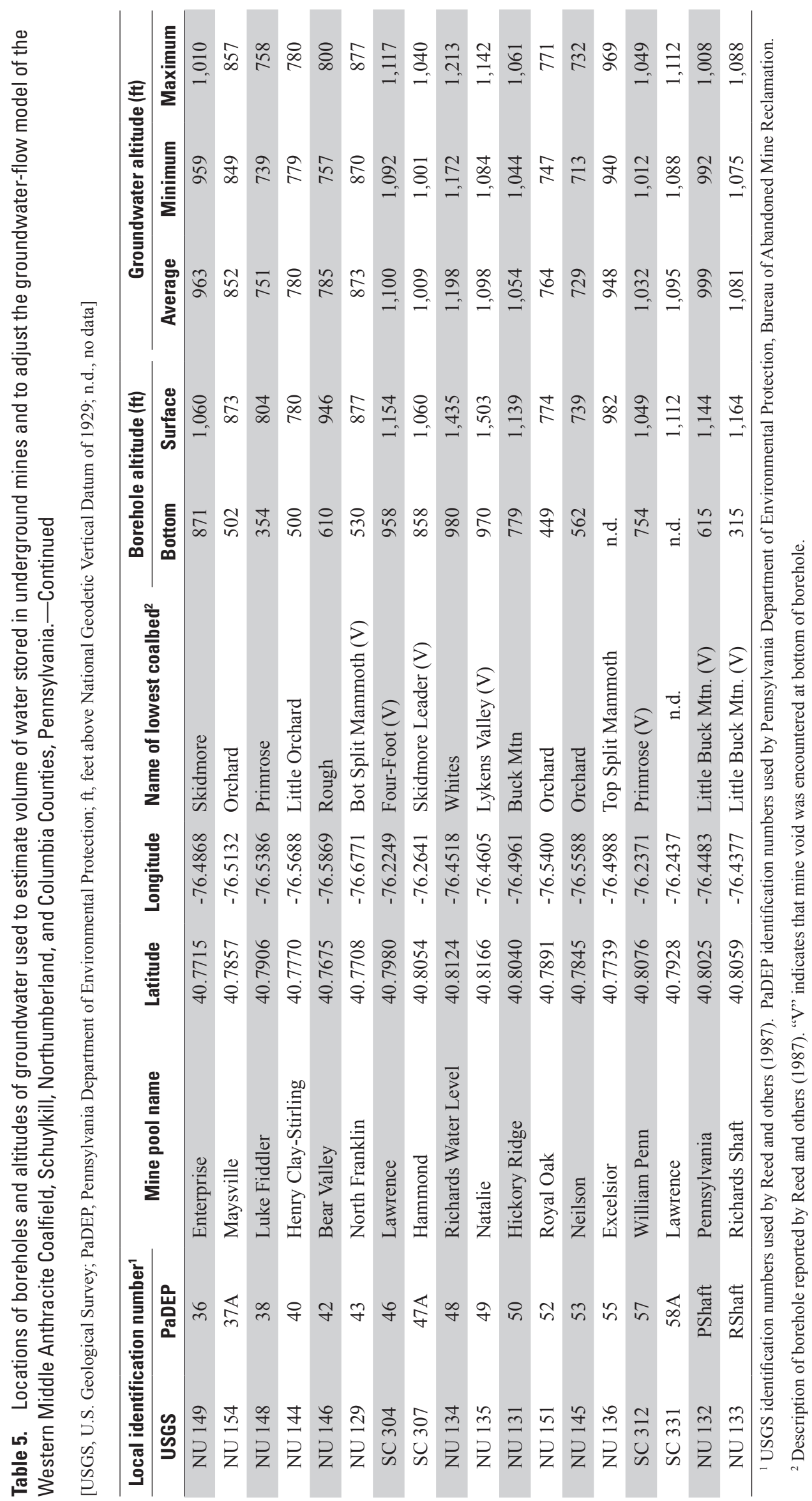


For additional information, write to:

Director

U.S. Geological Survey

Pennsylvania Water Science Center

215 Limekiln Rd.

New Cumberland, PA 17070

or visit our Web site at:

http://pa.water.usgs.gov/

Document prepared by the West Trenton Publishing Service Centers 
